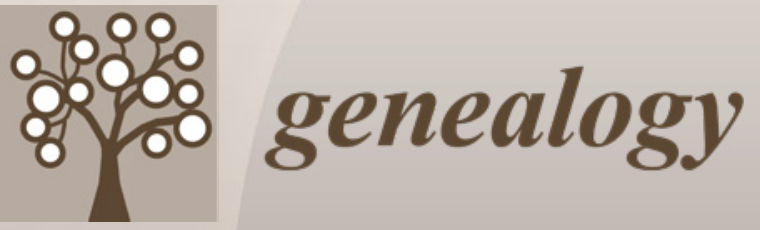

Transnationalism and Genealogy

Printed Edition of the Special Issue Published in Genealogy 
Transnationalism and Genealogy 



\section{Transnationalism and Genealogy}

Special Issue Editor

Philip Q. Yang

MDPI • Basel • Beijing • Wuhan • Barcelona • Belgrade

MDPI 
Special Issue Editor

Philip Q. Yang

Department of Sociology,

Texas Woman's University

USA

Editorial Office

MDPI

St. Alban-Anlage 66

4052 Basel, Switzerland

This is a reprint of articles from the Special Issue published online in the open access journal Genealogy (ISSN 2313-5778) in 2019 (available at: https:/ /www.mdpi.com/journal/genealogy/special_issues/ transnationalism).

For citation purposes, cite each article independently as indicated on the article page online and as indicated below:

LastName, A.A.; LastName, B.B.; LastName, C.C. Article Title. Journal Name Year, Article Number, Page Range.

ISBN 978-3-03921-908-7 (Pbk)

ISBN 978-3-03921-909-4 (PDF)

(C) 2020 by the authors. Articles in this book are Open Access and distributed under the Creative Commons Attribution (CC BY) license, which allows users to download, copy and build upon published articles, as long as the author and publisher are properly credited, which ensures maximum dissemination and a wider impact of our publications.

The book as a whole is distributed by MDPI under the terms and conditions of the Creative Commons license CC BY-NC-ND. 


\section{Contents}

About the Special Issue Editor $\ldots \ldots \ldots \ldots \ldots \ldots \ldots \ldots \ldots$

\section{Philip Q. Yang}

Transnationalism and Genealogy: An Introduction

Reprinted from: Genealogy 2019, 3, 49, doi:10.3390/genealogy3030049 . . . . . . . . . . . . . . 1

\section{Angellar Manguvo}

Emancipating the "Kin beyond the Sea": Reciprocity between Continental and Diasporic Africans' Struggles for Freedom

Reprinted from: Genealogy 2019, 3, 12, doi:10.3390/genealogy3010012 . . . . . . . . . . . . . . . 9

\section{Haiming Liu}

From Traditional to Transnational: The Chung Family History as a Case Example

Reprinted from: Genealogy 2019, 3, 46, doi:10.3390/genealogy3030046

\section{Jenny Banh}

"I Have an Accent in Every Language I Speak!": Shadow History of One Chinese Family's Multigenerational Transnational Migrations

Reprinted from: Genealogy 2019, 3, 36, doi:10.3390/genealogy3030036 . . . . . . . . . . . . . . 41

\section{Dwaine Plaza and Lauren Plaza}

Facebook and WhatsApp as Elements in Transnational Care Chains for the Trinidadian Diaspora

Reprinted from: Genealogy 2019, 3, 15, doi:10.3390/genealogy3020015 . . . . . . . . . . . . . . . 55

\section{Min Zhou and Jun Wang}

Challenges and Strategies for Promoting Children's Education: A Comparative Analysis of Chinese Immigrant Parenting in the United States and Singapore

Reprinted from: Genealogy 2019, 3, 20, doi:10.3390/genealogy3020020 . . . . . . . . . . . . . . 75 



\section{About the Special Issue Editor}

Philip Yang holds a Ph.D. degree in Sociology from the University of California at Los Angeles (1993) and is currently Professor of Sociology and Director of the sociology graduate program at Texas Woman's University (TWU). Yang is the author of Asian Immigration to the United States (Polity, 2011), Ethnic Studies: Issues and Approaches (SUNY Press, 2000), and Post-1965 Immigration to the United States: Structural Determinants (Praeger, 1995) and the editor of Introduction to Ethnic Studies: A Reader (Kendall/Hunt, 1999). He has published nearly 90 articles on immigration, citizenship, transnationalism, race and ethnicity, Asian Americans/immigrants, Chinese immigration and immigrants, and demography in numerous peer-reviewed journals, including International Migration Review, Diaspora, International Migration and Integration, Ethnic and Racial Studies, Journal of Asian American Studies, Journal of Chinese Overseas, International Sociology, Sage Open, and in edited volumes such as Ethnic Los Angeles (Russell Sage Foundation, 1996). His research has received funding from various sources, including the National Science Foundation. Yang's article "A Theory of Asian Immigration to the United States" won the Research Paper Award of the Asia and Asian America Section of the American Sociological Association in 2011. Yang has been named the TWU Chancellor's Research Fellow multiple times and received the TWU Distinction in Scholarship Award in 2017. He is a recipient of the 2019 Albert Nelson Marquis Lifetime Achievement Award. 



\title{
Editorial
}

\section{Transnationalism and Genealogy: An Introduction}

\author{
Philip Q. Yang \\ Department of Sociology, Texas Woman's University, Denton, TX 76204, USA; pyang@twu.edu
}

Received: 3 September 2019; Accepted: 11 September 2019; Published: 15 September 2019

\begin{abstract}
Transnationalism and genealogy is an emerging subfield of genealogy. The field has witnessed a significant growth in the last two to three decades, especially in the areas of transnationalism and family arrangements, transnational marriage, transnational adoption, transnational parenting, and transnational care for elderly parents. However, large gaps remain, especially with regard to the impact of transnationalism on lineage. Articles in this Special Issue fill some of the gaps. Additional research is called for.
\end{abstract}

Keywords: transnationalism; genealogy; transnational marriage; transnational adoption; transnational parenting; transnational care; lineage

Since the Call for Papers for the Special Issue on "Transnationalism and Genealogy" was announced last summer, all the manuscripts that were submitted, peer reviewed, and accepted have now been published. I would like to take this opportunity to offer my laconic assessment of the subfield of transnationalism and genealogy, situate the published articles of this Special Issue in the field, and point to directions for future research in this field.

\section{Transnationalism and Genealogy as an Emerging Subfield}

The modern English term "genealogy" may be traced to the Middle English word "genealogie," which may originate from Old French, Late Latin, and Greek. Together, "genea" (generation, descent, family) and "logy" (study) mean the study of family lineage or pedigree. Genealogy is as old as the human history. Genealogy started with an oral tradition and evolved into written family records. As an academic discipline, genealogy began in approximately 1500 (Encyclopedia Britannica 2019). In contrast, transnationalism as a new approach to the study of international migration is still in its nascence as it was introduced by anthropologists Basch, Glick Schiller, and Blanc-Szanton in the early 1990s, most systematically in their seminal book Nations Unbound published in 1994. However, since then the literature on transnationalism has seen geometric growth, and "transnationalism" has become a buzz word in many fields including, but not limited to, anthropology, sociology, political science, history, and so on.

Transnationalism is classically defined by Basch et al. (1994, p. 7) as "the processes by which immigrants forge and sustain multi-stranded social relations that link together their societies of origin and settlement." This classic definition of transnationalism has met with some challenges by other scholars (see, for example, Portes et al. 1999, p. 219). Along the line of Portes and his associates, I define transnationalism as the processes in which immigrants as well as their social institutions engage in regular and sustained involvement in economic, political, social, cultural, or personal practices across national borders (Yang 2006). The conscious endeavor to intersect transnationalism and genealogy is however very much lacking. Transnationalism can be a very fruitful and instrumental approach to the study of genealogy.

Essentially, the mission of the subfield of transnationalism and genealogy is to examine the relationship between transnationalism and genealogy. The impact of transnationalism on family relations, family history, and family lineage across the globe ought to be at the center of the 
subfield. Many topics will naturally fall into the domain of this subfield. An inexhaustive list will include at least the following: The impact of immigrant transnationalism on family relations; the role of immigrant transnationalism in writing or rewriting family histories; the effect of immigrant transnationalism on family lineage; the role of transnational marriage in transnational family dynamics; cross-border intra-ethnic, interethnic, and interracial marriages and bloodline; the role of transnational adoption in transnational family relations; transnational adoption and lineage; the prevalence of transnational families; transnational family arrangements; transnational motherhood, fatherhood, and childhood, and their differences from traditional motherhood, fatherhood, and childhood; transnational childrearing practices; transnational healthcare; effects of migration policies on transnational families; contexts in the countries of origin and destination, and decisions on transnational family separation or reunification; transnational migration and familial naming practices; and new horizons or insights brought by transnationalism to the field of genealogy.

\section{Where We Are and Where We Go from Here}

As an emerging field, transnationalism and genealogy has seen a significant growth in the last two to three decades, often intersecting with family studies, anthropological research, and sociological research. However, large gaps in the literature remain. This section highlights some significant themes and suggests pathways to move forward.

\subsection{Transnationalism and Family Arrangements and Relations}

Transnationalism has reshaped family structure and relations. Transnationalism has created transnational families whose members are separated in different nation-states but sustain close family ties across borders. Existing studies have identified a variety of transnational family arrangements created by immigrant transnationalism including "astronaut" families (e.g., Alaggia et al. 2001; Aye and Guerin 2001; Chee 2005), "parachute kids" (e.g., Hamilton 1993a, 1993b; Zhou 2009), and left-behind children by transnational parents, mostly mothers (Dreby 2007, 2010; Hondagneu-Sotelo and Avila 1997; Parreñas 2001). In astronaut families, the family head (called "astronaut"), typically the father, stays in the home country and/or travels to multiple countries while the spouse and children live in the host country. Parachute kids are minor children whose parents reside in the homeland but who attend schools in the host country alone or are cared for by relatives or legal guardians, caregivers, or landlords. Left behind children are those who stay in the home country often with grandparents or other relatives but whose parents migrate to the host country. More recent studies reveal another phenomenon dubbed "satellite babies," who were born to young Chinese immigrants or students in the United States and Canada and were sent back to China, Taiwan, and Hong Kong for care by mostly their grandparents, or sometimes other relatives, for an extended period of time, ranging from several months to several years (Bohr and Tse 2009; Wang 2018). These satellite babies typically reunite with their parents after the family has achieved financial security or when they have reached school age. These new family arrangements have impact on family relations and family members, especially children. What needs to be researched further is how prevalent or typical these transnational family arrangements are, or whether these patterns only occur to a few select immigrant groups, and if so, why. Research on children left behind by fathers is very limited, albeit existent (Parreñas 2008; Pribilsky 2012; Schmalzbauer 2015). The analysis of parachute kids is largely descriptive in nature, and in particular, the long-term impact of parachuting on these children calls for research.

\subsection{Transnationalism and Lineage}

In many societies, lineage was traditionally associated with ancestral land. In some Asian societies such as China, lineage was tied to ancestral hall, collectively owned ancestral land, and a genealogy (Zheng 1992). Some studies have demonstrated how Chinese diaspora, especially business elite or huashang, helped revive or construct ancestral land, ancestral properties (e.g., school, 
cultural center, science building), ancestral organizations, and genealogy for lineage members (Song 2008). Nevertheless, research on transnationalism and lineage is very thin. Theorization about the relationship between transnationalism and lineage and a systematic empirical analysis of the effect of transnationalism on lineage are cried for.

\subsection{Transnational Marriage}

In the age of globalization, transnational or cross-border marriages have become increasingly common. Many transnational marriages, including "mail-ordered brides," today often involve women of the poorer and less developed global south to the richer and more developed global north, a phenomenon dubbed "global hypergamy" (Constable 2005). Despite country-level differences in the level of economic development, some of these cross-border brides from developing countries have a higher socioeconomic status in terms of education and occupation than their husbands in developed countries (e.g., Oxfeld 2005; Thai 2005). Some of these brides are less marriageable domestically because they are divorced, too old (e.g., over 30), too educated, or too successful. Some hope to escape the constraints of local patriarchal marriages and to have a modern marriage abroad. Some desire to have an easier family lifestyle than in the home country. All of these could lead to expected or unanticipated outcomes in the marriages and family lives. While there is a significant amount of research on how transnational marriage has shaped family relations, including imbalance of husband-wife power, division of labor within the household, marital satisfaction or dissatisfaction, risks, vulnerabilities, tensions, abuses, termination of marriage, and even health problems (e.g., Charsley 2005; Freeman 2005; Ko 2012; Kudo 2016; Straiton et al. 2019; Wang 2007), the impact of transnational marriage on lineage remains a blank spot.

\subsection{Transnational Adoption}

Since the mid-1950s, transnational adoption has gradually turned into an institution and industry and gained popularity not only in the United States but also in Australia, Canada, and Europe. In the mid-1970s and 1980s, Korean adoption was the dominant source of transnational adoption to the United States. Since then, sources of transnational adoption to the United States have turned global (Condit-Shrestha 2018). Bulgaria and China have become the top source countries of adoption to the United States in recent years (Condit-Shrestha 2018; Yang 2011). Transnational adoption is an avenue to "the globalization of kinship." Transnational adoption has profoundly changed the traditional concept of kinship and family relations. As Modell (1994) compellingly argued, it creates "kinship with strangers" by legally and practically severing genetic ties and inventing new family relations with biologically unrelated parties. Unlike domestic adoption, transnational adoption is often transracial. For adoptees, "family" is not freely chosen, and kinship is constructed by the global political economy and the nation-state (Kim 2007). Much has been written about transnational adoption, especially Korean adoption, and its impact on family relations, adoptee identity, racialization, citizenship, and well-being (see, for example, Dorow 2006; Kim 2010; Laybour 2018; Nelson 2016; Oh 2015; Pertman 2001). For example, Korean adoptees often report feelings between the races, cultures, and identities of their adoptive parents and their biological being, and they also feel the conditional acceptance within Asian communities and a lack of visibility in mainstream American culture (Laybour 2018; Nelson 2016). Nevertheless, there is very little research on the effect of transnational adoption on lineage.

\subsection{Transnational Parenting}

Transnational family arrangements have resulted in family physical separation between parents and children and entailed transnational parenting or childrearing across borders. The current literature has examined various aspects of transnational parenting practices and experiences. What is documented is that transnational parenthood differs from traditional parenthood in "parenting at a distance" or physical absence together with social presence, but transnational parenting roles in childrearing are strongly gendered with greater expectations for migrant mothers than for migrant fathers 
(Dreby 2007, 2010; Hondagneu-Sotelo and Avila 1997; Parreñas 2001, 2005, 2008). Migrant mothers and migrant fathers also have differential influences on the experiences of left-behind children (Parreñas 2001, 2005). Transnational fostering could be part of normal lives in transnational families (Åkesson et al. 2012). The separation between migrant parents and children left behind could be long and indefinite especially when parents' legal status is an issue (Menjívar 2006; Schmalzbauer 2004). Beside sending remittances and presents and occasional home visits, long-distance, cross-border communication is very important for parent-child relationships. Migrant parents try to be socially and emotionally present in children's lives despite their physical absence. In spirit, they are both "here" and "there" (Hondagneu-Sotelo and Avila 1997), but in reality, this is difficult to accomplish. The means of communication has evolved from letters to phone calls and to Skype, email, and Internet-based social media (e.g., Facebook, Twitter, WeChat, WhatsApp) via computer, cell phone, and tablets in more recent decades. However, research on parent-child communication using more advanced technology remains very limited. The differential impact of children's age at separation from their parents on children's lives and especially their psychological development is seldom researched. Uniformly qualitative research at a small scale on this topic can be complemented by quantitative research.

\subsection{Transnational Care for Elderly Parents}

Globalization has led to an increase in occupational mobility with growing numbers of individuals seeking employment abroad. Life expectancy has continued to rise globally. Globalization and global aging, the two global processes, have given rise to the need of care for elderly parents in their home countries or caregiving across national borders (Dhar 2011). Anthropologists Baldassar et al. (2007) have done seminal work in this emerging field. Through their ethnographic work in nine immigrant communities in Western Australia, they demonstrate the transnational caregiving experiences and practices of Australian migrants and refugees who cared for their elderly parents in Europe, Asia, the Middle East, and New Zealand. Transnational care can be realized through different forms, including migrant family members travelling back to the home country to provide care, care users travelling across borders to receive care, and care providers travelling across borders to deliver care (Baldassar et al. 2007; Gorfinkiel and Escriva 2012; Yeates 2009; Zechner 2008). We have seen some growth in transnational caregiving literature in the last decade or so (e.g., Baldassar and Merla 2014; Bauer and Österle 2016; Gorfinkiel and Escriva 2012). Nonetheless, overall research on transnational caregiving is still in its infancy. Data beyond anecdotes and a small scale of interviews and observation are very much needed. In particular, how to use modern communication technology in transnational caregiving deserves special attention.

\subsection{Transnationalism and Writing/Rewriting Family Histories}

Transnationalism necessitates writing and rewriting family histories from a new perspective. With the growth of transnational families in the age of globalization, it is important that we write family histories from a transnational perspective. It would be mistaken to assume that transnational families are aberrant, pathological, traumatizing, or detrimental for the family and children (Zentgraf and Chinchilla 2012). Family histories should reflect transnational family arrangements and relations, transnational lineage, transnational marriage, transnational adoption, transnational parenting, and transnational caregiving.

\section{This Special Issue}

This Special Issue of Genealogy represents an initial attempt to examine the relationship between transnationalism and genealogy. The five articles published in this Special Issue cover various aspects of transnationalism and genealogy from historical periods until the present, with perspectives from anthropology, sociology, history, and African studies.

Angellar Manguvo's essay "Emancipating the 'Kin beyond the Sea'" investigates the inherent link between transnationalism and the emancipation of black kinship in a macro perspective. She documents 
the reciprocal impact of diasporic Africans on the liberation of Africa from colonialism on the one hand and of continental Africans on anti-racism in the United States on the other at the turn of the 19th century. She cogently demonstrates that black Africans, whether in the continent of Africa, the United States, or elsewhere are kin who can trace their origins to black groups in Africa, and that the emancipation of continental Africans from colonialism and the freedom of African Americans from racism are intrinsically connected.

In a micro perspective, Haiming Liu portrays how the Chung family had transformed from a traditional family to a transnational family and how this transformation had changed its family relations and lineage. Using family letters and other archive materials as data, he traces the 4-generation genealogy of the Chung family from Zhandong (great grandfather) to Chunli (grandfather), Yitang (father), and Sam from Guangdong in China to America, spanning from the 18th century to the early 20th century. The study focuses on filial piety as a Chinese family cultural principle, equal inheritance of land among sons, and competitions and conflicts over family property among brothers. In telling the Chung family story, the essay sheds light on the complex Chinese family culture and family relationships among family members and the impact of migration and immigrant transnationalism on the Chung family's relations, lineage, and history. It is fascinating that the paper also covers how immigration changed the naming practice and father-son nominal relationship.

In the tradition of oral history, Jenny Banh tells an interesting story of her family's transnational migration across four nations-city states in four generations. Through the narrative of her own family history, she throws light on multigenerational transnational migration, transnational family arrangements, the impact of transnational migration on family relationships and family lineage, and contexts in the countries of origin and destination and decisions on transnational family separation or reunification.

In filling the lacuna of transnational caregiving literature, Dwaine Plaza and Lauren Plaza's article examines the role of social media platforms, and especially Facebook, in facilitating transnational care-chains in the Trinidadian diasporic community by using data from two online surveys and ten in-depth interviews with Trinidadian immigrants in Toronto, Canada. Their article contends and demonstrates that social media have become a virtual transnational bridge linking the Trinidadian Diaspora across borders and provided family members with a sense of psychological well-being. What is significant is that the paper shows how social media have transformed transnational care arrangements and transnational family relationships.

In examining transnational parenting or childrearing practices, Min Zhou and Jun Wang's essay compares the parenting of Chinese immigrants in the United States and Singapore with a focus on challenges and strategies for promoting children's education. The study detects similar parental expectations on, and strategies for, children's educational achievements among Chinese immigrant parents in both the United States and Singapore. Their approach of interaction between cultural strategies and structural factors, such as resources from host social institutions and family and ethnic social networks, is more convincing than a simple cultural explanation for understanding the success in boosting children's educational accomplishments.

All of these articles fit one or more areas of transnationalism and genealogy that need research. However, more studies are called for to fill the gaps. This Special Issue is only the beginning of research on this subfield and hopes to attract more valuable contributions in the years to come.

Funding: This research received no external funding.

Conflicts of Interest: The author declares no conflict of interest.

\section{References}

Åkesson, Lisa, Jørgen Carling, and Heike Drotbohm. 2012. Mobility, Moralities, and Motherhood: Navigating the Contingencies of Cape Verdean Lives. Journal of Ethnic and Migration Studies 38: 237-60. [CrossRef] 
Alaggia, Ramona, Shirley Chau, and Ka Tat Tsang. 2001. Astronaut Asian Families: Impact of Migration on Family Structure from the Perspective of the Youth. Journal of Social Work Research 2: 295-306.

Aye, Alice, and Bernard Guerin. 2001. Astronaut Families: A Review of Their Characteristics, Impact on Families, and Implications for Practice in New Zealand. New Zealand Journal of Psychology 30: 9-15.

Baldassar, Loretta, and Laura Merla, eds. 2014. Transnational Families, Migration and the Circulation of Care: Understanding Mobility and Absence in Family Life. New York: Routledge.

Baldassar, Loretta, Cora Baldock, and Raelene Wilding. 2007. Families Caring across Borders: Migration, Ageing, and Transnational Caregiving. Basingstoke: Palgrave.

Basch, Linda, Nina Glick Schiller, and Cristina Blanc-Szanton. 1994. Nations Unbound: Transnational Projects, Postcolonial Predicaments, and Deterritorialized Nations-States. Postfach: Gordon and Breach Science Publishers.

Bauer, Gudrun, and August Österle. 2016. Mid and Later Life Care Work Migration: Patterns of Re-organization Informal Care Obligations in Central and Eastern Europe. Journal of Aging Studies 37: 81-93. [CrossRef] [PubMed]

Bohr, Yvonne, and Connie Tse. 2009. Satellite Babies in Transnational Families: A Study of Parents' Decision to Separate from Their Infants. Infant Mental Health Journal 30: 265-86. [CrossRef] [PubMed]

Charsley, Katharine. 2005. Unhappy Husbands: Masculinity and Migration in Transnational Pakistani Marriages. The Journal of the Royal Anthropological Institute 11: 85-105. [CrossRef]

Chee, Maria. 2005. Taiwanese American Transnational Families. New York: Routledge.

Condit-Shrestha, Kelly. 2018. South Korea and Adoption's Ends: Reexamining the Numbers and Historicizing Market Economies. Adoption and Culture 6: 364-400. [CrossRef]

Constable, Nicole. 2005. Cross-Border Marriages: Gender and Mobility in Transnational Asia. Philadelphia: University of Pennsylvania Press.

Dhar, Erica. 2011. Transnational Caregiving: Part 1, Caring for Family Relations across Nations. Care Management Journals 12: 60-71. [CrossRef]

Dorow, Sarah. 2006. Transnational Adoption: A Cultural Economy of Race, Gender, and Kinship. New York: New York University Press.

Dreby, Joanna. 2007. Children and Power in Mexican Transnational Families. Journal of Marriage and Family 69: 1050-64. [CrossRef]

Dreby, Joanna. 2010. Divided by Borders: Mexican Migrants and Their Children. Berkeley: University of California Press.

Encyclopedia Britannica. 2019. Available online: https://www.britannica.com/topic/genealogy (accessed on 1 August 2019).

Freeman, Caren. 2005. Marrying Up and Marrying Down: The Paradoxes of Marital Mobility for Chosŏnjok Brides in South Korea. In Cross-Border Marriages: Gender and Mobility in Transnational Asia. Edited by Nicole Constable. Philadelphia: University of Pennsylvania Press, pp. 80-100.

Gorfinkiel, Diaz, and Angeles Escriva. 2012. Care of Older People in Migration Contexts: Local and Transnational Arrangements between Peru and Spain. Social Politics 19: 129-41. [CrossRef]

Hamilton, Denise. 1993a. A House, Cash and No Parents. Los Angeles Times, June 24, pp. A1, A16.

Hamilton, Denise. 1993b. Chinese American Leaders Call for Action on "Parachute Kids" Immigrants: Taiwan Is Urged to Cut the Flow of Children Sent alone to Attend U.S. Schools. Programs Are Proposed to Combat the Isolation of Those already Here. Los Angeles Times, July 29, B3.

Hondagneu-Sotelo, Pierrette, and Ernestine Avila. 1997. "I'm Here, but I'm There": The Meanings of Latina Transnational Motherhood. Gender \& Society 11: 548-71. [CrossRef]

Kim, Eleana. 2007. Our Adoptee, Our Alien: Transnational Adoptees as Specters of Foreignness and Family in South Korea. Anthropological Quarterly 80: 497-531. [CrossRef]

Kim, Eleana. 2010. Adopted Territory: Transnational Korean Adoptees and the Politics of Belonging, Durham: Duke University Press.

Ko, Chyong-Fang. 2012. Marital Power Relations and Family Life in Transnational Marriages-A Study of Asian-French Couples Residing in France. EurAmerica 42: 249-79.

Kudo, Masako. 2016. The Evolution of Transnational Families: Bi-national Marriages between Japanese Women and Pakistani Men. Critical Asian Studies 49: 18-37. [CrossRef]

Laybour, Wendy. 2018. Being a Transnational Korean Adoptee, Becoming Asian American. Contexts 17: 30-35. [CrossRef] 
Menjívar, Cecilia. 2006. Liminal Legality: Salvadoran and Guatemalan Immigrants' Lives in the United States. American Journal of Sociology 111: 999-1037. [CrossRef]

Modell, Judith. 1994. Kinship with Strangers: Adoption and Interpretations of Kinship in American Culture. Berkeley: University of California Press.

Nelson, Kim Park. 2016. Invisible Asians: Korean American Adoptees, Asian American Expereinces, and Racial Exceptionalism. New Brunswick: Rutgers University Press.

Oh, Arissa. 2015. To Save the Children of Korea: The Cold War Origins of International Adoption. Stanford: Stanford University Press.

Oxfeld, Ellen. 2005. Cross-Border Hypergamy? Marriage Exchanges in a Transnational Hakka Community. In Cross-Border Marriages: Gender and Mobility in Transnational Asia. Edited by Nicole Constable. Philadelphia: University of Pennsylvania Press, pp. 17-33.

Parreñas, Rhacel S. 2001. Servants of Globalization: Women, Migration, and Domestic Work. Stanford: Stanford University Press.

Parreñas, Rhacel S. 2005. Children of Global Migration: Transnational Families and Gendered Woes. Stanford: Stanford University Press.

Parreñas, Rhacel S. 2008. Transnational Fathering: Gendered Conflicts, Distant Disciplining and Emotional Gaps. Journal of Ethnic and Migration Studies 34: 1057-72. [CrossRef]

Pertman, Adam. 2001. Adoption Nation: How the Adoption Revolution Is Transforming America. New York: Basic Books.

Portes, Alejandro, Luis E. Guarnizo, and Patricia Landolt. 1999. The Study of Transnationalism: Pitfalls and Promise of an Emergent Research Field. Ethnic and Racial Studies 22: 217-37. [CrossRef]

Pribilsky, Jason. 2012. Consumption Dilemmas: Tracking Masculinity, Money and Transnational Fatherhood between the Ecuadorian Andes and New York City. Journal of Ethnic and Migration Studies 38: 323-43. [CrossRef]

Schmalzbauer, Leah. 2004. Searching for Wages and Mothering from afar: The Case of Honduran Transnational Families. Journal of Marriage and Family 66: 1317-31. [CrossRef]

Schmalzbauer, Leah. 2015. Temporary and Transnational: Gender and Emotion in the Lives of Mexican Guest Worker Fathers. Ethnic and Racial Studies 38: 211-26. [CrossRef]

Song, Ping. 2008. The Zheng Communities and the Formation of a Transnational Lineage. Journal of Chinese Overseas 4: 183-202. [CrossRef]

Straiton, Melanie, Tone Ansnes, and Naomi Tschirhart. 2019. Transnational Marriages and the Health and Well-being of Thai Migrant Women Living in Norway. International Journal of Migration, Health and Social Care 15: 107-19. [CrossRef]

Thai, Hung Cam. 2005. Clashing Dreams in the Vietnamese Diaspora: Highly Educated Vietnamese Overseas Brides and Low-Wage U.S. Husbands. In Cross-Border Marriages: Gender and Mobility in Transnational Asia. Edited by Nicole Constable. Philadelphia: University of Pennsylvania Press, pp. 145-65.

Wang, Hong-zen. 2007. Hidden Spaces of Resistance of the Subordinated: Case Studies from Vietnamese Female Migrant Partners in Taiwan. International Migration Review 41: 706-27. [CrossRef]

Wang, Leslie. 2018. Chinese American "Satellite Babies," Raised between Two Cultures. Contexts 17: 24-29. [CrossRef]

Yang, Philip Q. 2006. Transnationalism as a New Mode of Immigrant Labor Market Incorporation: Preliminary Evidence from Chinese Transnational Migrants. Journal of Chinese Overseas 2: 173-92. [CrossRef]

Yang, Philip Q. 2011. Asian Immigration to the United States. Cambridge: Polity Press.

Yeates, Nicola. 2009. Globalizing Care Economies and Migrant Workers: Explorations in Global Care Chains. Basingstoke: Palgrave Macmillan.

Zechner, Minna. 2008. Care of Older Persons in Transnational Settings. Journal of Ageing Studies 22: 32-44. [CrossRef] Zentgraf, Kristine, and Norma Chinchilla. 2012. Transnational Family Separation: A Framework for Analysis. Journal of Ethnic and Migration Studies 38: 345-66. [CrossRef] 
Zheng, Zhenman. 1992. Ming-Qing Fujian jiazu yu shehui bianqian (Social Transformation and the Lineage Institution of Fujian during the Ming and Qing Periods). Hunan: Jiaoyu Publishing House.

Zhou, Min. 2009. "Parachute Kids" in Southern California: The Educational Experience of Chinese Children in Transnational Families. In Contemporary Chinese America. Edited by Min Zhou. Philadelphia: Temple University Press, pp. 202-18.

(c) (i) BY

(C) 2019 by the author. Licensee MDPI, Basel, Switzerland. This article is an open access article distributed under the terms and conditions of the Creative Commons Attribution (CC BY) license (http://creativecommons.org/licenses/by/4.0/). 
Perspective

\title{
Emancipating the "Kin beyond the Sea": Reciprocity between Continental and Diasporic Africans" Struggles for Freedom
}

\author{
Angellar Manguvo \\ Department(s) of Medical Humanities and Bioethics, University of Missouri-Kansas City, \\ Kansas, MO 64110, USA; manguvoa@umkc.edu
}

Received: 31 January 2019; Accepted: 17 March 2019; Published: 20 March 2019

check for updates

\begin{abstract}
While the African Diaspora's relentless commitment to the liberation of Africa from colonial bondage is well documented, the literature has, arguably, obscured the profound inspirations that Continental African people have had on Black Americans' struggles against racism. Unfortunately, the downplaying of the pivotal role of the forces from Continental Africa divorces the understanding of the interconnectedness of transnational black consciousness. This paper contributes a greater balance to the understanding of black racial solidarity by discussing the formation and sustenance of the interrelationships between Continental African people and the African Diaspora, particularly in the United States, during the struggles of anti-colonialism in Africa and anti-racism in the United States, dating back to the turn of the 19 th century. The paper conceptualizes the interconnectedness of the twin struggles from the cross-national diffusion theoretical framework. The theory offers appealing explanations and insights to the apparent mutuality regarding the formation, processes, outcomes, and consequences of the twin struggles. Galvanized by the common vision of emancipating the black race, the two movements were inspired by the exchange of ideological and organizational tactics, of which the exchange itself constituted another solid ideological tactic.
\end{abstract}

Keywords: transnationalism; cross-national diffusion; Pan-Africanism

\section{Introduction}

When I was a graduate student at a predominantly white Midwestern university, I had the honor to serve as an executive board member of a student organization that was dominated by African American graduate students. At that same time, I was also actively involved with an African students' organization, which was predominantly constituted by graduate students from sub-Saharan Africa. Apart from the shared common racial identity of their affiliated members, the two student organizations shared commonalities in historical experiences and challenges, all directly or indirectly linked to perpetual white domination. Interestingly, there were also fundamental differences between the two student organizations. The African American student organization was a discursive space for black identity expression, where African American students organized and deliberated on challenges they faced in their quest for recognition and equality amidst perceived contexts of prejudicial racial attitudes against black people. On the contrary, the African students' organization provided a forum through which members shared views on political, social, and economic challenges facing contemporary Africa. In view of the commonalities and apparent differences between the two black student organizations, I fathomed what would happen if the two organizations had merged into one; how would the students interact? Would that change their agendas? In trying to envision the merging of the two black student organizations, I was stimulated to investigating the meaning of the black racial identity. I was also eager to explore the nature of the historical connection between Continental African people and the 
African Diaspora. What socio-historical factors have influenced their relationship? What were the implications of their connectedness, if any, on the development of transnational resistance to racism and colonialism?

\section{Defining Blackness}

Having been a member of two distinct black student organizations stimulated me to investigate the meaning of blackness. In general terms, blackness is a racial designation assigned to people based on phenotypical characteristics such as skin color and hair texture. However, the meaning of blackness is more complex and cannot be strictly conceptualized in the simplistic view of phenotypical features. As Kusow (2006) argues, one cannot fully understand blackness without considering the historical, cultural, and political contexts within which categories of social stratification are constructed. Manguvo (2012) considers the institutionalization of slavery as the moment of inception of blackness in the United States, while the advent of colonialism brought about the concept of blackness in Africa. Thus, in addition to the phenotypical connotations, blackness is also a constructed identity upon which people of the African descent mobilize and defend themselves against perpetual white domination. In the context of the United States, blackness has followed several historical trajectories, since the period of slavery, which include post-slavery segregation, civil rights struggles, emancipation, and reconstruction to the modern-day struggles for equality and addressing of historical imbalances. Continental Africans also have an understanding of blackness as a determinant of social, political, and economic differentiation. Similar to slavery in the United States, European imperialism initiated racial hierarchies that left long-lasting effects throughout the African continent. Slavery and colonialism, thus, provoked transnational perspectives of blackness, which manifested through Pan-Africanist movements. The movements culminated in twin struggles across the Atlantic, both of which were aimed at emancipating the black race from subjugation (Manguvo 2018).

While the African Diaspora's relentless commitment to the liberation of Africa from colonial rule is well documented (see, for example, Campbell 1994; Erhagbe and Ifidon 2008; Gramby-Sobukwe 2005; Gwekwerere 2014; Hayes 2005; Lynch 1978; Parker 2009; Von Eschen 1997), the literature has, arguably, obscured the profound inspirations that Continental African people had on Black Americans' struggles against racism. There is little public awareness of the interconnectedness of the movements and yet, as Minter (2008), submits, the ties, both organizational and personal, had powerful effects on how both struggles were executed. As Meriwether (2002) posits, Black Americans were not just proactively engaged in the liberation of Africa, but they also obtained profound inspiration from the people of and activities in Africa. Unfortunately, the downplaying of the pivotal role of the forces from Continental Africa divorces the understanding of the interconnectedness of black racial solidarity. Guided by the cross-national diffusion theory, the paper discusses the formation and sustenance of the transnational relationships between Continental African people and the African Diaspora during the twin struggles against colonialism in Africa and racism in the United States, dating back to the turn of the 19th century. Galvanized by the common vision of emancipating the black race, the two movements were energized by the reciprocal exchange of ideological and organizational tactics.

\section{The Cross-National Diffusion Theory}

McAdam and Rucht's (1993) cross-national diffusion theory provides an appealing theoretical framework through which mechanisms of the interconnectedness between the twin struggles against racism in the United States and colonialism in Africa can be examined. Guided by fundamental quest to construe social change, the theory seeks to explain how social movements influence one another across national borders. According to Hayes (2005), the social movement diffusion process entails the spread of the motivation to participate as well as the sustenance of emotional commitment to a movement. As Walsh-Russo (2004) further submits, cross-national diffusion also occurs when one social movement transmits ideology, tactics, and perceptions of chances of success to the other social movement. These phenomena are shared through various channels of diffusion, which can be 
either relational, by direct interpersonal contact, or non-relational through different kinds of media (McAdam and Rucht 1993).

The cross-national diffusion theory pinpoints mutual identification as a fundamental mechanism for the diffusion to take place. The connection between Africa and the African Diaspora is rooted in their shared African ancestry. As Holmes (2002) postulates, the shared African identity is grounded on the idea that black people, no matter where they reside in the world, are African descendants; as such, they recognize Africa as an ancestral homeland (Holmes 2002). The connection between Africa and the African Diaspora during the period in question was not only rooted in ancestral ties, it was also reinforced by shared experiences of oppression. Racial consciousness stirred the development of a united front between Africa and its Diaspora. The quest for independence movements in Africa to end the racial segregation that characterized the socio-political processes of the colonial rule was quite comparable to anti-racism struggles in the United States.

Chabot and Duyvendak (2002) posit that cross-national diffusion is not only top down, but it is also bottom-up. This implies the existence of reciprocal transmission and reformulation of tactics and strategies. In line with reciprocity traits of diffusion, this paper seeks to demonstrate that the struggles for independence in Continental Africa and the anti-racism protests in the United States were interconnected. Additionally, the cross-national diffusion theory purports that movements are not orchestrated by single, discrete actors; instead they must be construed as dynamic incidents of concerted effort by multiple actors (Walsh-Russo 2004). In keeping with this, this paper unveils collective critical roles played by political and civil rights activists, intellectuals, religious leaders, black students, the Black Press, political organizations, and other grassroots organizations across the Atlantic in developing a mutual understanding between Africa and its Diaspora on the quest for freedom. Although inexperience, powerlessness, and many other factors may have impeded the efforts on many instances, the quest to raise consciousness of a shared common fate and the need for collaboration was, by and large, fruitful (Gramby-Sobukwe 2005). Arguably, the collectiveness of efforts contributed immensely to the movements' success.

\section{The African Diaspora's Engagement on Africa's Struggles}

There is an unquestionable articulation of numerous inextricable efforts by the African Diaspora to emancipate Africa from colonial and racial subjugation from as far back as the turn of the 19th century. Key players in these early efforts include black intelligentsia, the Black Press, labor unions, and non-governmental organizations. It is, however, important to note that the African Diaspora's engagement in African struggles for independence did not arise uniformly (Von Eschen 1997). As Meriwether (2002) submits, there was an abundance of differing forms and degrees of interest in the motherland, and, resultantly, the degree of engagement expended varied. Regardless of inherent differences on the level of interest and engagement, there is no question that the African Diaspora initiated and maintained unwavering commitment to liberate and emancipate Continental Africa from colonial and racial subjugation (Manguvo 2018).

The Chicago Conference on Africa, convened in 1893, was one of the earliest attempts by the African Diaspora to address the plight of Africa. The Congress combined intellectual, ideological, religious, philosophical, and scientific ideas to formulate a public policy on the status of Continental and Diasporic Africans (Reed 1971). In other words, the conference aimed at inspiring a responsibility among the African Diaspora of liberating Africa from colonialism. Similar goals and sentiments to liberate Africa were echoed at a follow-up conference held in Atlanta, Georgia in 1895.

Following political cultivations from these early meetings, black consciousness came into full conception in 1900 when Henry Sylvester Williams, a London-based black barrister from Trinidad organized a conference in London. The conference was attended by 32 delegates from Europe, Africa, and the Caribbean and came up with resolutions, which included an appeal for European leaders to grant African colonies rights to self-governance. The London conference ushered in a remarkable point in Diasporic Africans' commitment to the liberation of Africa from European imperialism. It is 
not surprising that, following this conference, the spirit of Pan-Africanism began to sow its seeds into various parts of Africa and the African Diaspora. Conceptualized as both a political and racial philosophy and a movement, Campbell (1994, p. 285) defines Pan-Africanism as 'an exercise in consciousness and resistance [which] reflects the self-expression and self-organization of African people.' The movement aimed at promoting feelings of oneness among people of the African descent, Continental or abroad, with the goal of self-restoration and emancipation from perpetual white domination (Manguvo 2016). The early decades of the 20th century, thus, witnessed the formation of the Niagara Movement in 1905, whose ideals paved the way to the formation of the National Association for the Advancement of Colored People (NAACP) in the United States in 1909. Although most of the organizations in the United States primarily focused on civil rights, they played a vital role in laying the foundation for emancipation of Africa from European imperialism.

\subsection{Pan-African Congresses}

Feelings of mandated responsibility by the African Diaspora to liberate Africa took full force through a series of Pan-African congresses that were organized throughout the first half of the 20th century. The first Pan-African congress was organized by Du Bois in 1919 and was attended by sixty representatives from sixteen nations, protectorates, and colonies and included members of the NAACP and some black women's rights activists. The congress came in the aftermath of World War I, which, as Du Bois (1996) submits, "was a war over spheres of influence in Asia and Africa." Attendees resolved to exert pressure on delegates of the Versailles Peace Conference to consider "the importance of Africa in the future world" as well as to "give the Negro race of Africa a chance to develop unhindered by other races" (Du Bois 1996). An appeal for the establishment of a Human Rights Charter that would guide European colonial powers' relations with native Africans, guided by the League of Nations, was forwarded to delegates of the Versailles Peace Conference. The congress also demanded, among other things, the abolishment of slavery and capital punishment of colonial subjects especially in the Belgian Congo. The delegates also demanded the right to education for African natives.

Although European powers represented at the Versailles Peace Conference were non-committed to any of these demands (Adejumobi 2001), a notable impact of the 1919 Pan-African Conference was the pledge by Queen Victoria of England to "not to overlook the interests and welfare of the native races" (Du Bois 1996, p. 7). As Gwekwerere (2014) reiterates, what is even more significant from outcomes of this Pan-African Conference is the commitment by the African Diaspora to a collective responsibility to liberate Africa regardless of the physical separation from the mainland.

The Pan-Africanists reconvened and held major congresses in London and Brussels in 1921 and 1923 respectively and echoed earlier resolutions of denouncing European imperialism in Africa and racism in the United States. The fifth Pan African congress, organized by London-based George Padmore and Kwame Nkrumah of Ghana and held in Manchester in 1945, was pivotal for Pan-African movements. A record number of African scholars, intellectuals, and political activists attended the congress, and these include Jomo Kenyatta of Kenya, Hastings Banda of Malawi, and Patrice Lumumba of the Congo; who later became influential leaders on the African continent. It was at the 1945 congress that a commitment was made to decisively radicalize the movement for African freedom and strategic military approaches for liberation of African countries were adopted (Adi and Sherwood 2003).

If the western world is still determined to rule mankind by force, then Africans [ . . . ] may have to appeal to force in the effort to achieve freedom, even if force destroys them and the world. We are determined to be free. (Asante and Abarry 1996, p. 520)

The asserted declaration of militant approach later manifested in the form of armed liberation movements in several African countries such as Kenya, Mozambique, Namibia, and Zimbabwe as well as mass protests in Congo, Ghana, Malawi, Nigeria, and Zambia. Throughout these struggles, the African Diaspora maintained an unwavering commitment towards complete emancipation of Africa from European domination. Regardless of the non-commitment by the dominant forces towards 
addressing Pan-Africanists' demands, there is no question that Pan-African movements played a major role in the struggle for Continental Africa's freedom (Manguvo 2018).

Alongside Pan-African congresses, several organizations and movements advocating freedom and emancipation of Africa also gained momentum in different parts of the African Diaspora. For example, the Universal Negro Improvement Association (UNIA), founded in 1914 by Marcus Garvey, a Jamaican-born nationalist and United States immigrant, played a pivotal role in the 1920s. In fact, Garvey was one of the pioneer Diasporic Africans to perpetuate the notion of the link between Africa and the African Diaspora. Thus, in addition to advocating for civil rights for black people in the United States, UNIA also primarily advocated for total emancipation of Continental Africa from European subjugation. Throughout his life, Garvey worked tirelessly to foster consciousness of African origins among the African Diaspora and solidarity among people of the African decent (Von Eschen 1997):

... we are going to seek a method of saving Africa first. Why? And why Africa? Because Africa has become the grand prize of the nations. Africa has become the big game of the nation hunters. Today Africa looms as the greatest commercial, industrial and political prize in the world [ ... ] we shall march out in answer to the cry of our fathers, who cry out to us for the redemption of our own country, our motherland, Africa. (Garvey 1986, p. 97)

On the other hand, the International African Service Bureau (IASB), founded by George Padmore in 1937, mobilized activists from Africa and the Caribbean to promote Pan-African unity. The bureau intended to address issues relating to Africa and the African Diaspora to the British general public. The IASB also sought to inform the public about the grievances faced by African people in the mainland. They created a list of desired reforms and freedoms that would help African colonies. The bureau also hoped to encourage new African trade unions to affiliate themselves with the British labor movements.

During the same period, the Council of African Affairs (CAA) was exerting pressure on the United States government to implement policies that would expedite the advent of African independence (Watson and Johnson 2000). Described by Lynch (1978) as the most important American organization concerned with Africa, the CAA served as an educational bureau devoted to dissemination of information about Africa. As time progressed, leaders of the CAA adopted more expressively political sentiments of liberating colonized African nations. As the demands for independence of Africa grew stronger, the CAA propagated the promotion of anticolonial sentiments in the United States and consistently put the issue of liberation of Africa on the United States agenda (Von Eschen 1997). They insisted that Black Americans' fight for civil rights was inseparably intertwined with the liberation movements in Africa. In light of that embodiment, it is not surprising that the CAA provided concrete assistance to African nationalist movements (Gwekwerere 2014).

Other organizations in the United States such as the American Committee on Africa (ACOA), did not only campaign against colonialism, but also provided concrete assistance and sponsorship to African liberation movements (Von Eschen 1997). Constituted mainly by Black Americans and some White civil rights activists, the ACOA formed strong network in global support of the African struggle. The ACOA members traveled extensively to Africa, attending African people's conferences and visiting newly independent countries and the Frontline States to meet with African leaders. The ACOA also offered educational opportunities in the United States to future African leaders. Among them were Tom Mboya, a Kenyan trade unionist and educationist, as well as Oliver Tambo of South Africa.

\subsection{International Events}

The African Diaspora's engagements on the liberation Africa from colonialism were facilitated by multiple historical trajectories, which inevitably shaped the world in various forms in the 20th century. The events include the rising of Fascism, World Wars, the Cold War, and the invasion of Ethiopia by Italy in the 1930s (Meriwether 2002). 
The invasion of Ethiopia by Italy in the 1930s was one international event that cemented the connectivity between Continental Africa and the African Diaspora. Black Americans viewed the United States' non-involvement approach to the Italo-Ethiopian war as being rooted in racism (Gramby-Sobukwe 2005). It was, therefore, imperative for Black Americans to take it upon themselves and create platforms through which diverse efforts in defense of Ethiopia could be executed. According to Gramby-Sobukwe, the efforts include mobilizing and sending resources, increasing awareness about the Ethiopian crisis, as well as protesting the US non-involvement policy. They also formed alliances, nationally and internationally, to help defend Ethiopia. Those who were most actively involved include scholars and intellectuals, grassroots community organizers, and religious groups. As the invasion was unfolding, Black Americans called upon the League of Nations to intervene and stop the invasion. For Gramby-Sobukwe, the petition represented a significant extension of the African Diaspora's involvement in the affairs of the motherland. The defense of Ethiopia was a significant event in the interrelationship between Africa and its Diaspora. As Scott (1993) noted, African-Americans spoke about the Ethiopian crisis with a nationalistic rhetoric, which demonstrates mutual identification. Their perspective of Ethiopians' cause was fundamentally a part of the struggle of the racial emancipation of the black race (Erhagbe and Ifidon 2008).

The onset of the Cold War in the late 1940s also had tremendous ramifications on the African Diaspora's commitment to the emancipation of Africa. According to Berg (2007), the global ideological confrontation between Communism and Liberal Democracy and the claim by the United States of leading the free world made domestic racial discrimination an international embarrassment. It was becoming more evident that America's problematic race relations were having a negative impact on her diplomatic endeavors (Krenn 1996). Galvanized by the understanding of these international dynamics, Black Americans exerted more pressure towards both eradication of racial segregation at home and elimination of colonialism in Africa.

On the other hand, the outbreak of World War II accelerated the already heightened sensitivity against colonialism in Africa among the African Diaspora. As the war brought to light fundamental issues of racial prejudice, Black Americans took advantage of the ideological battle against Nazism to condemn notions of white supremacy in both Africa and the United States (Von Eschen 1997). Anti-Nazism had far-reaching ramifications on American domestic policies regarding institutionalized racism as it increasingly sought to protect its image to the outside world. World War II, thus, ushered in a new political dispensation in the United States in which anti-colonialism acquired prominence, standing alongside with anti-racism in the domestic arena. Taking advantage of the new political constellation, Black Americans' advocacy for colonial freedom for Africa gained continued momentum as they relentlessly pushed the subject to the forefront of contemporary political discourses in the United States.

\subsection{The Role of Black Churches}

The key scholarship on anticolonial activism among the African Diaspora has, unfortunately, focused mainly on Pan-Africanist intellectuals and has overlooked the galvanizing anti-colonial deliberations by the black churches. Religious groups in the United States undeniably played a pivotal role in shaping, driving, and advancing the anti-colonialism agenda. As Martin (2015) submits, black churches often opened their minds and doors in solidarity with the African liberation struggle as most church leaders joined hands with intellectuals in preaching the gospel that was centered on Christian brotherhood. Using tenets of black liberation theology, the clergy and their parishioners initiated, participated in, and supported anti-colonial movements and organizations in various ways. For example, Harlem-based black churches provided financial support to the ACOA and the CAA. In addition to financial support, black churches also hosted some of the organizations' activities. When Italy invaded Ethiopia, several black churches in the United States took public positions in support of Ethiopia (Gramby-Sobukwe 2005). 


\subsection{The Role of Black Universities}

While the role of Diasporic African intellectuals on emancipating the African motherland has been well documented in the Black history scholarship, the role of Black academic institutions in the United States is another crucial part of the network that has been largely overlooked (Parker 2009). Black universities indeed played an important role in the struggle against colonialism in Africa. After the abolition of slavery in the Americas, the now referred to as Historically Black Colleges and Universities (HBCU) in the United States began admitting black students including those from Africa and the Caribbean. By the 1950s, many foreign black students had enrolled to study in the United States. Due to the then racial stratification of the American society, most foreign black students attended HBCUs, where they met and exchanged ideas with Black American students. For example, it was at Lincoln University that Kwame Nkrumah of Ghana gained a better and deeper understanding of the conditions facing black people in the United States (Malisa and Nhengeze 2018). Many other African leaders were influenced immensely by their experiences at HBCUs as they learned from Black American activists and intellectuals. Furthermore, during the invasion of Ethiopia, some Black American scholars at HBCUs mobilized black students for a collaborated defense of Ethiopia. By early 1935, students from black universities began staging demonstrations against the invasion (Gramby-Sobukwe 2005). Black universities, therefore, internationalized Black Nationalism, where students' sense of racial solidarity helped diffuse ideas from America back to the motherland (Parker 2009).

Hayes (2005) has also chronicled how black student organizations such as the Student Nonviolent Coordinating Committee (SNCC) often engaged with African independence movements during the 1960s. Although the SNCC's overall objective of improving the conditions of Black Americans was maintained throughout its existence, their commitment to working with and supporting African independence movements was also enduring. The SNCC proposed multiple programs, which raised awareness and provided support for African independence movements. On some occasions, members of the student group traveled to African countries to provide political support for African independence. Indisputably, black universities provided an ideal ground for nurturing of Black Nationalism (Hayes 2005).

The African Diaspora's commitment to the liberation and emancipation of Continental Africa is unquestionable. Habituating in the still racially segregated United States, Black Americans relentlessly fought for the liberation of Continental Africa from European colonial domination. However, as some African countries were gaining political independence, the focus of the African Diaspora, particularly in the United States, shifted from anticolonial and transnational interests and more emphasis was now placed on domestic civil rights (Berg 2007).

\section{Continental Africa's Influence on Black Americans' Civil Rights Struggle}

Many scholars of black history have perceived civil rights movements within a domestic US-based framework. Viewing civil rights movements within a global framework, however, enhances appreciation of the motivations of those who challenged the status quo (Gaines 2007). Indeed, civil rights movements had global connections which may not have been abundantly noticeable during the contemporary times. Nonetheless, the connectivity between the civil rights movements and political uprisings in Africa was not a surprising phenomenon when one considers the comparability of the segregation laws in the United States to the socio-political processes of colonial rule such as Apartheid in South Africa. Although literature abounds with the African Diaspora's influence on the liberation of Africa from colonial rule, the profound reciprocal influence of Continental Africa on civil rights movements has been obscured. The following sections, thus, discuss ways through which events, activities, and people of Continental Africa influenced civil rights movements in the United States. 


\subsection{The Role of African Intellectuals Studying in the United States}

As stated earlier, following the abolition of slavery in the Americas, HBCUs in the United States began admitting black students including those from Africa and the Caribbean and, by the 1950s, a few African students had enrolled. During their stay in the United States, African students gained a deeper understanding of the conditions facing Black Americans in the racially stratified society (Mwakikagile 2007). Having been subjected to the same racial discrimination, many African students forged and strengthened ties with Black Americans in their struggles for racial equality.

Kwame Nkrumah of Ghana was one prominent African scholar who relentlessly condemned racism while studying in the United States. Nkrumah attended Lincoln University in Pennsylvania, one of the most prominent HBCUs. He also lived in Harlem, a predominantly black district, when he was a student at Columbia University. It was during his stay in Harlem that Nkrumah stood as a strong advocate for black freedom. He preached in black churches in Pennsylvania and New York condemning racism. Nkrumah was heavily invested in learning about civil rights organizations, which further strengthened his ties with Black Americans. Additionally, Nkrumah exhibited a strong interest not only in African history but also in Black American history. He even wrote a "Negro history" series for the student newspaper at Lincoln University and taught classes on the subject at the University of Pennsylvania. Considering these strong ties, it was not surprising that when he revisited Harlem as prime Minister of Ghana in 1958, he symbolized a victory that Black Americans could identify with and celebrate (Mwakikagile 2007). In his speech in Harlem during the visit, Nkrumah echoed the notion of the genealogical bond between Africa and its Diaspora.

Tom Mboya was another African intellectual who was committed, not only to the liberation of Continental Africans but also Diasporic Africans. As stated earlier, Mboya was a Kenyan trade unionist who came to the United States in 1956 under the sponsorship of the ACOA. While studying in the United States, Mboya spoke at rallies at colleges, universities, and several other places, most of which were organized by the ACOA (Garrow 2016). Mboya won the hearts of many Black Americans through his speeches. Resultantly, he fostered inextricable linkages with several civil rights movement leaders including A. Philip Randolph, Jackie Robinson, Harry Belafonte, Martin Luther King Jr., and others (Goldsworthy 1982). On 18 April 1959, Mboya, alongside Martin Luther King Jr., Charles Zimmerman, the civil rights chair of the a labor union, and Roy Wilkins of the NAACP, addressed a crowd of about 26,000, who had marched to the Washington Monument to urge the implementation of the Supreme Court's Brown v. Board decision (Garrow 2016). Two days later, Mboya gave another speech at an "Africa Freedom Dinner" organized by the Southern Christian Leadership Conference (SCLC) in Atlanta. Prior to Mboya's keynote address, Martin Luther King, Jr. reiterated the link between the civil rights movements and the African liberation movements:

I am absolutely convinced that there is no basic difference between colonialism and segregation. They are both based on the contempt of life, and a tragic doctrine of white supremacy. So, our struggles are not only similar, they are in real sense, one [ . . . We are all caught in an inescapable network of mutuality. (Garrow 2016)

It is apparent, therefore, that the civil rights movements embraced African intellectuals like Nkrumah and Mboya and, in return, the African scholars embraced the civil rights struggle. Undoubtedly, Pan-Africanists from the motherland and those in the Diaspora, particularly in the United States, were comrades-in-arms in the struggle for racial equality.

\subsection{The Role of African Liberation Struggles}

Comparable to the civil rights movements in the United States, African independence uprisings sought to end the racial segregation that characterized the socio-political processes of colonial rule. Independence uprisings in Africa were an invaluable source of inspiration for Black Americans' cause for freedom (Minter and Hill 2008). Walsh-Russo (2004) postulates that cross-national diffusion occurs when one social movement transmits ideology and tactics to the other movement. Diffusion of 
ideological tactics from African liberation struggles to civil rights movements was indeed evident throughout the various stages of the twin struggles.

Much like Mahatma Gandhi of India, Kwame Nkrumah considered non-violence as his ideological cornerstone to defeat colonialism in Ghana. The tactic entailed use of legitimate political agitation, educational campaigns, intelligent compromise, strikes, boycotts, and non-co-operation, all based on the principles of absolute non-violence (Owusu 2006). Perceiving colonization and segregation as twin evils sharing the same head, Martin Luther King Jr. advocated for similar non-violent "decapitation" (Mwakikagile 2007). He made direct references to Ghana (and India) as examples of progressive radical movements that rejected oppression through non-violent tactics. King remarked:

And it's a beautiful thing, isn't it? That here is a nation that is now free, and it is free without rising up with arms and with ammunition. It is free through nonviolent means. Because of that the British Empire will not have the bitterness for Ghana [ . . . ] Because of that when the British Empire leaves Ghana, she leaves with a different attitude than she would have left with if she had been driven out by armies. We've got to revolt in such a way that after revolt is over we can live with people as their brothers and their sisters. Our aim must never be to defeat them or humiliate them. (King 1992)

It is, therefore, arguable that Martin Luther King Jr. was a follower of Kwame Nkrumah's philosophy of non-violence. Nkrumah served as an inspiration to King, who often looked to his leadership as an example of non-violent activism. For King, the strategies and tactics that Nkrumah had employed in Ghana against colonialism were also needed to combat American racism and disenfranchisement. Regrettably, as Levitt (2017) argues, history has severely underplayed the extent to which Martin Luther King Jr. was invigorated by Kwame Nkrumah's philosophy.

Additionally, Nkrumah's quest for Continental unification also had a strong emotional appeal among many leaders of civil rights movements in the United States. Although the ambition of a United Africa was perceived controversially by many, it still stood out as a message of racial solidarity, which resonated perfectly among many Black Americans in their quest for racial equality (Mwakikagile 2007). Nkrumah's vision of United Africa probably inspired Malcolm X's formation of the "Organization of Afro-American Unity." This demonstrates the extent to which Malcolm X was influenced by Nkrumah's political ideology. Undoubtedly, Nkrumah's dream of a United Africa indeed inspired future generations within Continental Africa and the African Diaspora to work towards racial solidarity across the Atlantic.

Contrary to Nkrumah's non-violent approach, other African countries employed radicalized militant tactics in defiance to colonial rule. For example, the Mau Mau, a radical nationalist movement in Kenya, advocated violent resistance to British domination. Meriwether (2002) attests that (much like the non-violent approach of Ghana), the Mau Mau insurgency widened parameters of debate over how to combat racism in the United States as some black civil rights leaders preferred militant tactics.

Malcolm X was one proponent of the militant approach of resisting racism. He travelled to Africa 1964 where he spoke with several political leaders including Jomo Kenyatta of Kenya, Julius Nyerere of Tanzania, and Kwame Nkrumah of Ghana. It was during his trip and the inspiration he received from Pan-Africanists in the motherland that he refined his position on the anti-racism struggle. He was particularly inspired by the Mau Mau militant resistance to British colonial rule. As Meriwether (2002) attests, Malcolm X's militant preference is summed up by his controversially perceived "by any means necessary" phrase. He perceived the Mau Mau militant defiance as signaling the right way to dismantle white oppression. He even called on Black Americans to "even the score with Whites" by creating their own Mau Mau armies (Koster 2015). Malcolm X's advocacy for militancy, though controversial, resonated with a substantial number of Black Americans. Not surprisingly, a song giving praise to the Mau Mau revolution was sung at a rally organized by SNCC in Harlem in 1964. As Horne (2006) posits, Black Americans in Harlem were equating the phrase 'Mau Mau' with the notion of strength, fierceness, and determination in resistance to white domination. Following the 
song, Malcolm X used the platform to underscore the importance of the connections between Kenyans' resistance to British colonial rule and Black Americans' struggle against racism (Koster 2015).

Much like Malcolm X, many Black Southerners adhered to the Mau Mau style of self-emancipation. One such activist was Medgar Evers of Mississippi, the state's field secretary for the NAACP. Evers and his brother Charles grew very interested in African freedom movements, in particular, Jomo Kenyatta and the Mau Mau rebellion. Recognizing a similarity between Kenya's colonial segregation and the racial discrimination in Mississippi, Evers sought to build an organizational base for the NAACP that would directly challenge white supremacy in the Mau Mau style. Guided by his "eye for an eye" rhetoric, Evers encouraged mass action among Black Mississippians in resistance to Jim Crow (Henze 2017). Although he later renounced sentiments of violence, Evers maintained that he had greatly been inspired by Kenyatta and the Mau Mau militant approach. His efforts in resisting racism continually embodied the militant spirit of the Mau Mau resistance, thus, centering the Mississippi Freedom Movement within the contexts of Kenya's struggle for independence from British colonial rule (Horne 2009).

Overall, the significance of the Mau Mau rebellion as an inspirational symbol of black resistance to white oppression is unquestionable. As Koster (2015) argues, the Mau Mau rebellion facilitated the much-needed connections between Africa and its Diaspora by pushing Black Americans toward greater militancy. This is a clear demonstration of diffusion of ideological tactics between Africa and its Diaspora in their defiance to systems of white oppression.

\subsection{The Black Media}

The cross-national diffusion theory propounds that for social movement diffusion to occur, channels of diffusion should be in place and one such channel of diffusion is through different kinds of media. The information spreads across movements through non-direct ties when physical connections are not possible. Von Eschen (1997) and Meriwether (2002) chronicle the importance of the Black Press to the transnational structural connection between Continental Africa and the African Diaspora. African activists and journalists banded together in Black American newspapers to form a dense network with Black journalists and publishers in the Diaspora (Von Eschen 1997). For example, the magazine: Africa Today, first published in 1954 by the ACOA, served as a key source for transmission of African Nationalism to the African Diaspora. The Black print medium, therefore, facilitated dialogue between Continental African people and the African Diaspora about the commonalities in the injustices both societies were receiving because of race.

\subsection{The Role of African Nations' Attainment of Independence}

The emergence of new African nations as sovereign countries free from colonial rule in the 1950s and 1960s (whether through non-violence as was the case in Ghana or through militancy as was the case in Kenya) did change not only the destiny of the African continent, but also the plight of Black Americans as a result. The attainment of independence by African countries inaugurated a new spectrum of racial pride among Black Americans. Mwakikagile (2007) posits that, for the first time in modern history, black countries now had a voice of their own in the international arena; and this was a source of pride for Black Americans. As Mwakikagile further reiterates, their identification with Africa was no longer something they could be ashamed of; rather, the victory of their brethren in Africa was seen as their own victory. Not surprisingly, the racial pride inaugurated by the independence of African nations had a long-lasting impact on Black Americans' self-identity. According to Mwakikagile, it was during this period when propositions for Black Americans to call themselves "African Americans" (instead of being called Negroes) came into political and social discourses. The term "African Americans" was abound with political connotation of racial solidarity with fellow Africans who were emancipating themselves. Furthermore, the term was associated with, unity, militancy, and pride. 
In particular, the independence of Ghana in 1957, the first African nation to break the chains of colonial bondage, was very significant to Black Americans because of strong kinship connections with West Africa. Apparently, Kwame Nkrumah, the first president of Ghana, was very much aware of the significance of those genealogical ties as he stated in his Independence Day speech, "There exists a firm bond of sympathy between us and the Negro peoples of the Americas. The ancestors of so many of them came from this country ... (Nkrumah 1961)." In recognition of these strong geonealogical ties and, most importantly, their shared common fate, Nkrumah invited many Black Americans to Ghana for the independence celebrations. Among those invited were Martin Luther King Jr. and his deputy Ralph Abernathy, veteran civil right leader A. Philip Randolph, UN Undersecretary-General Dr. Ralph Bunche, as well as Harlem Congressman Adam Claytom Powell (Mwakikagile 2007).

Walsh-Russo (2004) submits that cross-national diffusion occurs when one social movement transmits chances of success to the other social movement. This is quite relatable with regards to the impact of African nations' attainment of independence on Black Americans' struggle. Considering the comparability between the twin struggles for civil rights in the United States and for independence in Africa, the resounding success recorded by some liberation movements in Africa in the late 1950s and 1960s, culminating in political independence, had intense inspiration for Black Americans' struggles against racism. For example, when Ghana attained political independence in 1957, one Black newspaper, The Pittsburgh Courier, published a 32-page "Salute to Ghana" article. In a front-page editorial, the Courier observed:

When we, American Negroes, shake hands with Ghana today, we say not only "Welcome!" but also, "Your opportunity to prove yourself is our opportunity to prove ourselves" (Zachary 2007).

Upon his return from Ghana's independence celebrations, Martin Luther King Jr. explained the lessons of the Ghanaian struggle in a series of speeches and sermons. For example, during his speech at the Dexter Avenue Baptist Church, he stated:

Ghana has something to say to us. It says to us first, that the oppressor never voluntarily gives freedom to the oppressed. You have to work for it. And if Nkrumah and the people of the Gold Coast had not stood up persistently, revolting against the system, it would still be a colony of the British Empire. Freedom is never given to anybody. For the oppressor has you in domination because he plans to keep you there, and he never voluntarily gives it up. And that is where the strong resistance comes. Privileged classes never give up their privileges without strong resistance. (King 1992)

The excerpts above are an indication of the often-underplayed extent to which Ghana's independence invigorated Black Americans' cause. As Levitt (2017) submits, King perceived Ghana's independence as a clear manifestation that "forces of the universe are on the side of justice," implying that Ghana's success was a symbol of assurance of the certainty of victory for Black Americans.

Although the connection between Malcolm X and Kwame Nkrumah has not been well documented, there is enough evidence that Nkrumah was a source of inspiration to Malcolm X, who in turn labeled Ghana the "fountainhead of Pan-Africanism." As Dokosi (2016) postulates, there is a lot to extrapolate about this connection from Nkrumah's letters, Malcolm's own diary, and the FBI and the CIA files that have been made public. Despite publicizing his meetings with Islamic leaders during his trip to Africa in 1964, Malcolm X reckoned his meetings with Nkrumah as "the highest honor of my life" (Koster 2015). Their connection is corroborated in Nkrumah's letters, in which he confirmed to have developed and maintained a relationship with Malcolm X until his assassination in 1965 (Milne 1990). As Dokosi (2016) opines, making his connection with Malcolm X public was potentially detrimental to Nkrumah's administration given that the US government had made clear of their displeasure. Considering that the newly founded nation of Ghana fairly relied on the United States and Britain for skills and resources, Nkrumah was torn between risking to lose the much-needed support 
from the super powers and making a public connection with Malcolm. Malcolm X corroborated this dilemma in his diary when he alluded to the pressures involved when African leaders were considering inviting him. The dilemma probably explains why neither of them dared to reveal much about their connection nor the contents of the discussions. Regardless of the threat from the US government, Nkrumah still went ahead and met with Malcolm X in 1964. This demonstrates his unwavering commitment to the principles of black emancipation.

In view of the inspirational value of African nations' attainment of independence, it is not surprising to note that the decade in which most African countries won independence was the very same decade in which civil right movements in the United States gained momentum. As Mwakikagile (2007) posits, the two movements did not only complement each other, but they also started in earnest on both sides of the Atlantic during the same period, and they also started advancing their victory during the same decade in the 1960s. Most importantly, the attainment of independence by African countries provided an opportunity for people of the African descent across the Atlantic to identify as a people of one ancestry with a common fate.

\subsection{The Organization of African Unity (Now African Union)}

Following the attainment of independence by a handful of African countries in the 1950s and 1960s, the Organization of African Unity (OAU) (now African Union) was formed in Addis Ababa, Ethiopia in 1963. The organization was committed to restoring the dignity of African people as well as fostering cooperation among African countries. Remarkably, the OAU demonstrated great interest in the civil rights struggles in the United States right at its formation. The organization issued a statement, which was incorporated into the OAU Charter, condemning racism and linking racial discrimination in the United States with Apartheid in South Africa:

The Summit Conference of Independent African States meeting in Addis Ababa, Ethiopia, from 22 may to 25 May 1963: having considered all aspects of the questions of apartheid and racial discriminations, unanimously convinced of the imperious and urgent necessity of coordinating and intensifying their efforts to put an end to the South African Government's criminal policy of apartheid and wipe out racial discrimination in all its forms [... ] [and also] EXPRESS the deep concern aroused in all African peoples and governments by the measures of racial discrimination taken against communities of African origin living outside the continent and particularly in the United States of America; EXPRESSES appreciation for the efforts of the Federal Government of the United States of America to put an end to those intolerable malpractices which are likely seriously to deteriorate relations between the African peoples and governments on the one hand and the people and Government of the United States of America on the other. (Cervenka 1971)

One year following the formation of OAU, Malcolm X made a trip to Africa and presented the cause of Black Americans at the OAU's second convention in Cairo, Egypt. He noted how the atrocities committed in Hungary, Latin America, and among the Jewish people of the Soviet Union were brought before the United Nations, yet the problems of Black Americans were being ignored. Malcolm X, therefore, appealed to African leaders to address the plight of Black Americans at the upcoming United Nations General Assembly convention. As Yeboah (2018) posits, the grand scheme of presenting Black Americans' plight to the United Nations would have been difficult to achieve if Black Americans championed this cause alone. Malcolm X's appeal culminated into resolutions by the OAU to reaffirm its concern about persistent racial discrimination in the United States and urging the US government to take deliberate steps to end racism (Mbughuni 2014). As Yeboah further submits, nine African countries agreed to take up the matter and bring it to the United Nations General Assembly during the convention; however, they did not do so for several reasons including political and diplomatic reasons. As discussed earlier, the US government had made clear of its displeasure with the connection between African newly formed governments and leaders of the civil rights movements. Being dependent 
upon the skills and resources from super powers, most African states were torn between meddling into US domestic issues and risk jeopardizing diplomatic relations or maintaining an unwavering commitment to emancipating the kin beyond the sea. In view of this political dilemma, it is, therefore, not surprising that the assassination of Malcolm X in 1965 seems to have apparently sealed the fate of his appeals to the OAU to have the plight of Black Americans brought to the United Nations. Regardless, as Yeboah (2018) rightfully opines, the OAU could still have done more to show solidarity with Black Americans than just passing non-binding resolutions. They could have been more vocal about the plight of Black Americans to the United Nations than they did.

Despite the apparent mediocre commitment by the OAU as a body, there were notable African leaders who continually spoke out against racial injustice in the United States and these include Kwame Nkrumah and Julius Nyerere of Tanzania. One year after Ghana's independence, Nkrumah visited the United States at the invitation of President Eisenhower. Reflecting on the close ties he had fostered with Black Americans during the time he was studying in the United States, Nkrumah used the occasion to condemn racial segregation against Black Americans. As Mwakikagile (2007) submits, many other governments of independent African nations issued statements condemning racial injustice in the United States.

\section{Conclusions}

The chronological coincidence of the struggles for independence in Continental Africa and anti-racism protests in the United States was not mere coincidence (Parker 2009). This paper discussed how collective efforts of political and civil rights activists, intellectuals, religious leaders, Black students at HBCUs, the Black Press, as well as the thousands of individuals and grassroots organizations across the Atlantic played critical roles in developing a foundation of mutual understanding between Africa and its Diaspora. Dating back to the turn of the 19th century, Africa and its Diaspora banded together as advocates of black emancipation at critical historical junctures. The connectedness of the two movements was both a symbol and a strategy for consolidating greater unity among people of the African descent. Arguably, the connectivity contributed significantly to the success of both movements. Pan-Africanism was the bricks and the mortar that cemented their structural connectivity. Undoubtedly, the growth of Pan-Africanism molded the African continent and its Diaspora into a solitary entity, thus, inspiring the development of a united front between Africa and its Diaspora. Against this background, it is not surprising that to date, the African Diaspora is represented in the African Union as it is considered an integral part of the African world.

The mutual inter-dependence between Africa and its Diaspora in the 1960s demonstrates an inextricable genealogical and historical connection between Continental Africa and the African Diaspora. As Gramby-Sobukwe (2005) submits, the instances where Africa and its Diaspora organized together, shared, learned, and advocated shared objectives is a fertile ground for enhancement of present-day collaboration. Although Pan-Africanism as a political movement has practically weakened, the genealogical connections between Africa and its Diaspora can still be redirected and harnessed towards continuous emancipation of the Black race in economic, cultural, and other social arenas.

Funding: This research received no external funding.

Conflicts of Interest: The author declares no conflict of interest

\section{References}

Adejumobi, Saheed A. 2001. The Pan-African Congress. In Organizing Black America: An Encyclopedia of African American Associations. Edited by Nina Mjagkij. New York: Garland Publishing, pp. 477-80.

Adi, Hakim, and Marika Sherwood. 2003. Pan-African History: Political Figures from Africa and the Diaspora since 1787. London: Routledge.

Asante, Molefi Kete, and Abu Shardow Abarry. 1996. African Intellectual Heritage: A Book of Sources. Philadelphia: Temple University Press. 
Berg, Manfred. 2007. Black Civil Rights and Liberal Anticommunism: The NAACP in the Early Cold War. The Journal of American History 94: 75-96. [CrossRef]

Campbell, Horace. 1994. Pan-Africanism and African Liberation. In Imagining Home: Class, Culture and Nationalism in the African Diaspora. Edited by Sidney Lemelle and Robin D. G. Kelley. London: Verso, pp. 285-307.

Cervenka, Zdenek. 1971. The Organization of African Unity in the Seventies. VRÜ Verfassung und Recht in Übersee 5: 29-39. [CrossRef]

Chabot, Sean, and Jan Willem Duyvendak. 2002. Globalization and Transnational Diffusion Between Social Movements: Reconceptualizing the Dissemination of the Gandhian Repertoire and the "Coming Out" Routine. Theory and Society 31: 697-740. [CrossRef]

Dokosi, Michael Eli. 2016. The Critical Union of Malcolm X and Kwame Nkrumah in the Fight against Oppressor's Rule. Available online: https:/ / www.blakkpepper.com/2016/05/the-critical-union-of-malcolm-x-kwamenkrumah-in-fight-against-oppressors-rule/ (accessed on 28 January 2019).

Du Bois, William Edward Burghardt. 1996. The Oxford WEB Du Bois Reader. New York: Oxford University Press, USA.

Erhagbe, Edward O., and Ehimika A. Ifidon. 2008. African-Americans and the Italo-Ethiopian Crisis, 1935-1936: The Practical Dimension of Pan-Africanism. Aethiopica: International Journal of Ethiopian Studies 11: 68-84. [CrossRef]

Gaines, Kevin. 2007. The Civil Rights Movement in World Perspective. OAH Magazine of History 21: 57-64. [CrossRef]

Garrow, David J. 2016. MLK: An American Legacy: Bearing the Cross, Protest at Selma, and the FBI and Martin Luther King, Jr.. New York: Open Road Media.

Garvey, Amy J. 1986. The Philosophy and Opinions of Marcus Garvey, or, Africa for the Africans. Dover: The Majority Press, vols. I and II.

Goldsworthy, David. 1982. Tom Mboya: The Man Kenya Wanted to Forget. New York: Africana Publishing Company. Gramby-Sobukwe, Sharon. 2005. Africa and US Foreign Policy: Contributions of the Diaspora to Democratic African Leadership. Journal of Black Studies 35: 779-801. [CrossRef]

Gwekwerere, Tavengwa. 2014. The African Diaspora in Continental African Struggles for Freedom: Implications on the Criticism of African Renaissance Literature. South African Journal of African Languages 34: 35-40. [CrossRef]

Hayes, Robin. 2005. The Dialogic Relationship between Black Power and African Independence: A Case Study of SNCC's Role, 1960-1970. Ann Arbor: Mpublishing, vol. 4, Available online: http://Hdl.Handle.Net/2027/Spo. Pid9999.0004.203 (accessed on 28 January 2019).

Henze, Kristin R. 2017. Mississippi Mau Mau: Medgar Evers and the Black Freedom Struggle, 1952-1963. Ph.D. dissertation, University of Missouri-Columbia, Columbia, MO, USA.

Holmes, Crystal. 2002. An Assessment of the Plausibility of Pan-Africanism from Various Perspectives. African Diaspora ISPs. Available online: https://digitalcollections.sit.edu/african_diaspora_isp/82/ (accessed on 28 January 2019).

Horne, Gerald. 2006. Toward a Transnational Research Agenda for African American History in the 21st Century. The Journal of African American History 91: 288-303. [CrossRef]

Horne, Gerald. 2009. Mau Mau in Harlem? The US and the Liberation of Kenya. New York: Palgrave Macmillan.

King, Martin Luther. 1992. The Papers of Martin Luther King, Jr., Volume III: Birth of a New Age, December 1955-December 1956. Berkeley: University of California Press.

Koster, Mickie Mwanzia. 2015. Malcolm X, the Mau Mau, and Kenya's New Revolutionaries: A Legacy of Transnationalism. Journal of African American History 100: 250. [CrossRef]

Krenn, Michael L. 1996. "Unfinished Business:" Segregation and US Diplomacy at the 1958 World's Fair. Diplomatic History 20: 591-612. [CrossRef]

Kusow, Abdi M. 2006. Migration and Racial Formations among Somali Immigrants in North America. Journal of Ethnic and Migration Studies 32: 533-51. [CrossRef]

Levitt, Jeremy I. 2017. Beyond Borders: Martin Luther King, Jr., Africa, and Pan Africanism. Temple International and Comparative Law Journal 31: 301.

Lynch, Hollis Ralph. 1978. Black American Radicals and the Liberation of Africa: The Council on African Affairs, 1937-1955. Ithaca: Africana Studies and Research Center, Cornell University. 
Malisa, Mark, and Phillippa Nhengeze. 2018. Pan-Africanism: A Quest for Liberation and the Pursuit of a United Africa. Genealogy 2: 28. [CrossRef]

Manguvo, Angellar. 2012. Making the Invisible Visible: Self-representation of African International Students at a Mid-Western University in the US. In Space, Transformation and Representation: Reflections on University Culture. Edited by Olatunde Bayo Lawuyi and Chinyere Ukpokolo. Glassboro: Goldline and Jacobs, pp. 129-60.

Manguvo, Angellar. 2016. Negotiating the Boundaries of American Blackness: The Experiences of African Students in the United States. In Exploring The Social And Academic Experiences of International Students in Higher Education Institutions. Edited by Krishna Bista and Charlotte Foster. Hershey: IGI Global, pp. 79-95. [CrossRef]

Manguvo, Angellar. 2018. Old and New Diasporic African People in Contemporary USA: Tracing the Relational Journey. Journal of Pan African Studies 12: 229-46.

Martin, Phyllis Slade. 2015. A Moral Imperative: The Role of American Black Churches in International Anti-Apartheid Activism. Ph.D. dissertation, George Mason University, Fairfax, VA, USA.

Mbughuni, Azaria. 2014. Malcolm X, the OAU Resolution of 1964, and Tanzania: Pan-African Connections in the Struggle against Racial Discrimination. The Journal of Pan African Studies 7: 177-94.

McAdam, Doug, and Dieter Rucht. 1993. The Cross-national Diffusion of Movement Ideas. The Annals of the American Academy of Political and Social Science 528: 56-74. [CrossRef]

Meriwether, James Hunter. 2002. Proudly We Can Be Africans: Black Americans and Africa, 1935-1961. Chapel Hill: University of North Carolina Press.

Milne, June. 1990. Kwame Nkrumah: The Conakry Years, His Life and Letters. London and Atlantic Highlands: PANAF.

Minter, William. 2008. An Unfinished Journey. In No Easy Victories: African Liberation and American Activists over a Half Century, 1950-2000. Edited by William Minter, Gail Hovey and Charles Cobb. Trenton: Africa World Press, pp. 9-58.

Minter, William, and Sylvia Hill. 2008. Anti-Apartheid Solidarity in United States-South Africa: From the Margins to the Mainstream. The Road to Democracy in South Africa 3: 745-822.

Mwakikagile, Godfrey. 2007. Relations between Africans and African Americans: Misconceptions, Myths and Realities. Pretoria: New Africa Press.

Nkrumah, Kwame. 1961. Africa Must be Free: A Message from Osagyefo Dr. Kwame Nkrumah, President of the Republic of Ghana, Delivered on the Third Anniversary of Africa Freedom Day, April 15, 1961. Accra: Afram Publications.

Owusu, Robert Yaw. 2006. Kwame Nkrumah's Liberation Thought: A Paradigm for Religious Advocacy in Contemporary Ghana. Pretoria: Africa World Press.

Parker, Jason C. 2009. "Made-In-America Revolutions"? The "Black University" And the American Role in the Decolonization of the Black Atlantic. The Journal of American History 96: 727-50. [CrossRef]

Reed, Adolph L., Jr. 1971. Pan-Africanism-ideology for Liberation? The Black Scholar 3: 2-13. [CrossRef]

Scott, William R. 1993. The Sons of Sheba's Race: African-Americans and the Italo-Ethiopian War, 1935-1941. Bloomington: Indiana University Press.

Von Eschen, Penny M. 1997. Race against Empire: Black Americans and Anti-Colonialism, 1937-1957. Ithaca: Cornell University Press.

Walsh-Russo, Cecelia. 2004. Diffusion of Protest. Sociology Compass 8: 31-42. [CrossRef]

Watson, Barrington, and Dudley Johnson. 2000. The Pan-Africanists. Kingston: Ian Randle Publishers.

Yeboah, Roland Mireku. 2018. From the Civil Rights Movement to Black Lives Matter: The African Union and the African-Americans in the United States. Journal of Pan African Studies 12: 166-90.

Zachary, Pascal G. 2007. Freedom for Blacks Rang First in Ghana 1957 Independence Inspired Americans. Available online: https:/ / www.sfgate.com/opinion/article/Freedom-for-blacks-rang-first-in-Ghana-19572650162.php (accessed on 28 January 2019).

(C) 2019 by the author. Licensee MDPI, Basel, Switzerland. This article is an open access article distributed under the terms and conditions of the Creative Commons Attribution (CC BY) license (http:/ / creativecommons.org/licenses/by/4.0/). 
Article

\title{
From Traditional to Transnational: The Chung Family History as a Case Example
}

\author{
Haiming Liu \\ College of Education and Integrative Studies, California State Polytechnic University, Pomona, CA 91768, USA; \\ hliu1@cpp.edu
}

Received: 4 March 2019; Accepted: 5 August 2019; Published: 8 August 2019

check for updates

\begin{abstract}
A harmonious family of three generations living under one roof is often an assumed image of a Chinese traditional family. In reality, few Chinese families resemble this image. My article uses the Chung family history to illustrate how a family in rural Guangdong, South China, experienced a fast social ascent or descent in one generation. Its history reveals many aspects of Chinese family tradition, such as filial piety, equal inheritance system among sons, and education as an important family agenda. The rise and fall of this family also help us understand the competitive social environment of Guangdong that sent hundreds of thousand immigrants overseas in the mid-nineteenth and early twentieth century. When some members of the Chung family migrated overseas, other members followed. The Chung lineage, similar to numerous Cantonese immigrant families in America, became transnational in culture.
\end{abstract}

Keywords: filial piety; equal inheritance system; ancestor halls; village schools; migration; transnational; Chinese family culture

\section{Introduction}

A harmonious family of three generations living under one roof is often an assumed image of a Chinese family. Sons revere parents; wives obey husbands; and brothers help each other in family affairs. While women did household chores, men toiled in carefully cultivated tiny rice fields in self-sufficient farming. This image stands for inadaptability and the changeless nature of Chinese family culture. Nothing resembles this image in reality. As a Chinese saying goes, the wealth of a family lasts no more than three generations (Fu bu guo san dai 富不过三代). British historian Hugh Baker keenly noted that the rise and fall in family fortunes in the 19th century meant Chinese society was similar to a seething cauldron, with families bubbling to the top only to burst and sink back to the bottom. ${ }^{1}$ In this article, I use the Chung family as an example to show how a family in rural Guangdong, South China, could experience a fast social ascent or descent in one generation. Its history reveals some of the most important Chinese family traditions, such as filial piety, equal inheritance principle among sons, and education as an important family agenda.

The rise and fall of the Chung family are more than a tale of family feuds over property. It also shows how Chinese families negotiated and adapted to the competitive economic and social environment of Guangdong in the 19th century. Some succeeded; many failed. Guangdong sent hundreds of thousand immigrants overseas between the mid-nineteenth and early twentieth century. When Yitang (Yick Hong Chung) and his eldest son Sam (Weixi Chung) of the Chung lineage migrated to America in the 1900s, other lineage members followed, and their kinship network transplanted overseas. Most

$1 \quad$ (Baker 1979). 
of them settled in America, but their ties to home were never severed. Similar to many immigrant families from Guangdong, the Chung family became transnational in life and culture. As immigrants, Yitang and Sam worked hard to support the family. As parents, they made sure their children could get a good education. They encouraged them to pursue educational opportunities in both China and America and maintain both English and Chinese ability. In Chinese family culture, the children's education was always a priority. When Yitang and Sam retired, they did not accumulate much wealth for themselves, but all their children had accomplished college education.

The Chung's family originated from a narrow region along the Zhujiang (Pearl) River Delta in Guangdong Province. The Chinese immigrants from this region further divided themselves based on three geographic districts- "Sanyi", "Siyi", and Zhongshan County. Sanyi included the districts (or counties) of Nanhai, Panyu, and Shunde; and Siyi included the counties of Xinhui, Taishan, Kaiping, and Enping. ${ }^{2}$ The Chung family lived in Niushan (Cattle Hill) Village, Kaiping County. The village had about four hundred families belonging to several different clans. Four families established ancestral halls and operated two to four schools, though not on regular basis. Among several rural markets in the area, the nearest one to Niushan Village was called Yung Ku Market, which operated all year round. The village had four wells for drinking water. In front of the village was a river that villagers used for irrigation in farming. There were also boats that transported villagers to and from Canton (Guangzhou) City. At the back of the village was a long brick wall with several gates. The Chung house was located in the heart of the village and was about one block away from the nearest gate. There were several family clans in the village. The Chung family was one of them. ${ }^{3}$

\section{The Origin of the Chung Family}

In China, some families composed and preserved books of genealogy, while many others passed stories of their ancestors orally from one generation to another. In a slight exaggeration, a British diplomat in the early twentieth-century China noted that "the commonest Chinaman can trace his descent back by memory from two hundred to five hundred years, or even more by referring to his 'genealogy' book at home". 4 We could not find a formal genealogy book for the Chung family, but Sam Chung, a pioneer immigrant of the family, wrote numerous letters to his children, brothers, uncles, and other relatives after arriving in America. Letter writing was an important tradition in Chinese family culture. Sam seemed thoroughly familiar with his family history. Many of his letters recounted events, stories, or anecdotes about his ancestors and other family affairs. Based on the Chung family letters and other archive materials, I could trace the Chung family origin from Sam's father Yitang to his grandfather Chunli and great grandfather Zhandong, and compose a rough three- to four-generation genealogical history of the Chung family (Supplementary Materials) in Guangdong. ${ }^{5}$ As we put pieces of information together, the Chung family story is detailed enough to inform us of some of the most important aspects of family culture in rural Guangdong. It also shows how a Cantonese immigrant family became transnational in culture.

Sam's great grandfather Zhandong (1780-1830) was the eldest son of a well-to-do farmer's family and had five brothers. He married Nie, daughter of a well-to-do family in a neighboring rural town, Beizha, who bore him one son and two daughters. Sam believed that the Chung family began to gain

2 Sanyi (Sam Yup in Cantonese), translated as the "Three Districts", is located to the west of Guangzhou (Canton); Siyi (Sze Yup in Cantonese), translated as the "Four Districts", located to the southwest of Sanyi; and Zhongshan (Heungsan in Cantonese) County located to the south of Sanyi. "Yi" actually means county or district in Chinese.

(Liu 2005).

(Parker 1901).

Information on Zhandong and Chunli is based on a genealogy of the Chung family composed by Lillian Wong, Yitang's daughter, an Announcement of Yitang's 70th Birthday Celebration, Special Booklet of Sam Chang and His Wife's 80th Birthday Anniversary, n.d. composed by Tennyson Chung, and transcripts of Nellie Chung Interview and Arthur Chung Interview conducted by Chinese Historical Society of Southern California in 1985, and Sam's letter to Tennyson and Constance on 3 January 1928. I have copies of those documents. Also see Liu, The Transnational History, pp. 13-28. 
wealth and social status from Zhandong's generation. In a letter to his children, Sam Chung explained why Zhandong deserved great respect in the family history:

Zhandong inherited a farm from his aging father that produced no more than a hundred dan of grain (one dan equates to approximately one hundred and eighty-five pounds) He worked hard, lived a thrifty life, and was able to increase his grain yield up to one thousand dan a year. That is his first achievement. Second, he was an educated person, knew law, and could write and handle legal papers and documents for relatives and friends. Third, he knew how to deal with the local tyrants when they tried to take advantage of his wealth. He avoided a lot of trouble. Fourth, he viewed polygamy as the root of misfortune. When he became the wealthiest man in the village and had only one son and two daughters, he did not marry more wives for more sons. Fifth, though he could inherit the best house of the family as the eldest son, he gave it away to the widow of his half and fifth brother out of his respect for his father's wish and chose a smaller house for himself. Sixth, as the eldest son, he made sure that the six brothers remained close and friendly long after their parents passed away. Seventh, he maintained a decent life style. Relatives who were addicted to opium smoking and gambling always stayed away from him. Eighth, in addition to farming, he ran a reading class and taught children of the clan until he was old. As descendants, we should learn the above eight qualities from him. He lived only about fifty years but he was a very happy person and enjoyed life in his senior years. ${ }^{6}$

Though the letter was not a detailed biography, it was long enough to reveal what Sam perceived as some of the most important qualities of Zhandong as an ancestor in the Chung lineage. He was an educated farmer, a benevolent eldest brother, and a person who preferred a small family. It is important to note that Sam did not begin his description of Zhandong by portraying him as a great model of filial piety. Zhandong was obviously a nice person respecting his father and taking care of his widowed sister-in-law. In Sam's letter, however, his first and most important quality was the ability to expand his farming wealth ten-fold in less than thirty years.

According to the letter, Zhandong inherited a farm that produced about a hundred dan of paddy rice per year. ${ }^{7}$ Since the average annual yield of paddy rice per $m u$ (one $m u$ equals one-sixth acre) in Zhujiang Delta was between two to four dan during that period, we could assume that the size of his farm was between twenty to thirty $m u$ large. ${ }^{8}$ Though Zhandong's farm was modest in size, it was above self-subsistence level. In the early nineteenth century, one dan of grain could feed an adult male for a hundred days, or sell for three hundred copper cash. An agricultural laborer's monthly wage was only between two hundred and four hundred and fifty copper cash. ${ }^{9}$ Zhandong was in his late twenties when he inherited his share from his father's estate and retired from farming in his mid-fifties. In less than thirty years, he was able to expand his farming wealth ten-fold more than what he had inherited from his father. This was an impressive accomplishment in rural Guangdong. Sam's letter provided no details on how he accomplished this success except praising his fugal lifestyle and hard-working spirit. Zhandong was obviously not a self-sufficient farmer who worked just to feed his family but a speculative agribusiness person who grew crops for sale. As anthropologist William Skinner observed, some speculative agribusiness people were able to expand their landed property and became rich within a short time because the commercial marketing system was well developed and organized in rural Guangdong. ${ }^{10}$

A letter from Sam to Tennyson and Constance on 3 January 1928.

One dan is equal to 2.94 US bushels and 1 hectoliter or equates approximately one hundred and eighty-five pounds. See (Faure 1989).

8 For the average yield of paddy rice per $m u$ in the Zhujiang Delta, see Faure, The Rural Economy, p. 48.

9 (Mazumda 1998).

10 (Skinner 1971) 
Between the late eighteenth to early nineteenth century, Guangdong was undergoing dramatic demographic changes. Its population grew from sixteen million in 1787 to twenty-eight million in $1850 .{ }^{11}$ According to historian Ping-ti Ho and Frederic Wakeman, Jr., the ratio of population to cultivable land in 1787 was 160 persons per square mile. It increased to 192 persons per square mile in 1812. The average cultivable land per person was $1.67 \mathrm{mu}$ in Guangdong, which was below the national average of $2.19 \mathrm{mu}$ in that year. ${ }^{12}$ This was a period of increasing social stratification and commercialization of farming. Cash crops began to replace self-sufficient farming in Guangdong. ${ }^{13}$ Life in a rural village was diverse and villagers' economic pursuits were multi-dimensional, since arable land could hardly meet the needs of the local population. As D. H. Kulp noted, a rural village in Guangdong could have clerks, salesmen, merchants, fruit dealers, carpenters, doctors, tailors, teachers, and many others, in addition to farming laborers and farmers. ${ }^{14}$ Many villagers did not own land. The average ratio of land to population in Guangdong was $7.8 \mathrm{mu}$ per family and only one million farmers owed their own land out of a total 12.5 million agriculturalists. ${ }^{15}$ Rice was not the only crop in Guangdong. The Zhujiang Delta also produced silk and sugar-cane. In the hilly areas, people grew tea, tobacco, vegetables, and various fruits. While some farming families toiled in carefully cultivated tiny rice fields for survival, many others pursued other livelihoods. Though arable land was insufficient, the Delta was one of the richest agricultural areas in China. Diversified commercial activities, prevalent lineage organizations, and a competitive social environment characterized rural Guangdong.

Zhandong was well educated, although he was not scholarly enough to earn a degree title through the civil service examination. Sam listed education and legal knowledge as his second most important qualities. He was rich but not malicious, and a highly respected farmer in the village. "When his wealth sometimes made him the target of envious and rapacious people, Zhandong's ability to write legal complaints enabled him to defend himself and gain the upper hand in the conflicts with other people during arbitration by the local government" ${ }^{16}$ During the Qing Dynasty, the land ownership system, legal codes on land property, and land sale procedures were all complicated issues. For example, tenant farmers could have permanent access to land as long as they paid tax. As permanent tenancy became another form of ownership, many properties could have two or three owners. ${ }^{17}$ Zhandong could not accumulate his land property smoothly without knowing the law. His ability to write legal documents was an important skill. A common legal document in Guangdong was the contract for renting, leasing, or tenancy ownership of family farming properties. According to James Hayes, most of social and economic transactions in Qing China were done in writing, and writers of such contracts were not parties to the transaction but probably their follow villagers, clansmen, or fellow townspeople. ${ }^{18}$ Zhandong was literary enough to handle commercial farming issues for himself or his fellow villagers.

Zhandong also enjoyed teaching. While farming, he taught children in a village school in his spare time and became a full time teacher after he retired. Zhandong's legal knowledge was rare among farmers but his teaching career was normal in rural Guangdong. Many villages had schools. Large clans usually built ancestor halls (ci tang) and used them as schools. Children attended them if their parents paid tuition. Many villagers, especially males, had a functional literacy because schooling was an integral part of the rural life in Guangdong. Ping-ti Ho's research on social mobility in imperial China emphasized that literacy was essential for the farmer families, not only for pursuing scholarly

\footnotetext{
(Takaki 1998).

(Ho 1959; Wakeman 1966).

Sucheta Mazumda's book Sugar and Society in China is a detailed documentation on the cash crop economy in Guangdong.

(Kulp 1966).

(Chen 1933). See also (Freedman 1958).

The Family Genealogy by Lillian Wong.

(Mazumda 1998, pp. 230-33).

(Hayes 1982).
} 
titles but also for successful farm management, and consequently there was a high degree of literacy among Chinese farmers. 19

Sam spoke highly of Zhandong's kindness towards his brothers. In Chinese family culture, there are two words that denote filial piety- “xiao 孝" and "ti 悌”. While "xiao" refers to respect and obedience to parents, "ti" means kindness toward siblings, especially brothers. In "ti" relationships, junior brothers should defer to their elder brothers, while the latter should display affection and care in return. In Chinese family culture, filial piety means respect to parents and affection for siblings. According to Sam, Zhandong was a caring and generous brother. As the eldest son, Zhandong could demand the best house of the family estate in property division, but let the widow of his fifth and half-brother take it. He set a good example of "ti" in sibling relationships. Sam saw him as a role model and carefully handled his own sibling relationship. When he joined his father Yitang in America, his father's second marriage added four younger siblings to the family-three half-sisters and one half-brother. Sam treated his American-born siblings kindly.

Sam admired Zhandong for his preference of a small family. Chinese family culture allowed polygamous marriage, as filial piety principle also encouraged men to marry concubines in order to have more sons to continue the family line. Zhandong had one son and two daughters but did not marry concubines to have more sons. He chose to have a small family with one wife and three children in order to maintain a harmonious family relationship. Chinese family culture disapproved of primogeniture and emphasized equal inheritance of family property among sons. However, more sons meant more competition over family property. A small family allowed Zhandong to keep his wealth undivided and give his only son Chunli a comfortable life and a good amount of wealth. He enjoyed a peaceful retirement life. Sam spoke highly of Zhandong's decision not to marry concubines because he knew how siblings of his father's generation mercilessly fought over property, which led to the decline of the Chung family.

\section{An Ancestor of Eighteen Children}

As the only son of Zhandong, Chunli (1805-1884) inherited all farming and housing property of the family. The Chung family's wealth continued to grow-from the wealthiest family in the village to one of the wealthiest families in the county. Several family documents mentioned that Chunli could collect four thousands dan of rice annually, which was four times larger than what Zhandong did. With this amount, Chunli probably owned or leased up to five hundred $m u$ or more of land, and had tenant farmers working for him. Chunli was known as one of the wealthiest landlords in Kaiping County of his time. Similar to Zhandong, he was an agribusiness person growing crops for sale rather than just to feed his family. He had tons of grain in the barn and a huge holding of land assets. ${ }^{20} \mathrm{He}$ could use the profit from sales of grain to purchase more land and expand his farming property. There were several markets close to Sam's village and the largest one was about six $l i$ (one Chinese $l i$ is equal to 0.31 miles) to the south of it. ${ }^{21}$ Bustling with all kinds of farming or other products, markets in xiang were the focus of villagers' economic and social activities, and an integral part of the rural life in Guangdong. ${ }^{22}$ During the Qing period, markets in rural Guangdong became very specialized, with fruits, grain, silkworm, pig, draft animal, fish, or even fabric markets opened regularly at various locations. ${ }^{23}$ Commercial activities were common among rural populations in the Chung family area. According to William Skinner, the market towns were so important that they shaped the local social structure

9 (Ho 1962)

20 The above information is from recollections of several old friends contained in Special Booklet.

21 One Chinese $l i$ is about 0.3107 mile. For location information, see the Chung family immigration files in the Records of the INS-Los Angeles District Segregated Chinese Case Files, 1893-1935: Files 4935/6 (Box108) at NARALN.

22 For a detailed discussion of market towns in Guangdong, see (Marks 1984).

23 (Yang and Zhong 1996). Mei and Zhang, eds. Wuyi huaqiao huaren shi. 
and integrated the peasant community into the total society. ${ }^{24}$ Chunli's family lived a comfortable life based on the rents paid by tenants. This was a period when many farmers went bankrupt and became tenant farmers or farming laborers. In the mid-nineteenth century, three to five percent of the population controlled about fifty to sixty percent of the cultivated land. Moreover, interregional and international trade led to the cultivation of cash crops rather than subsistence farming. ${ }^{25}$ In rural Guangdong, there were people living in poverty, as well as people such as Chunli who speculated and accumulated wealth fast through commercial farming.

As family wealth increased, the size of the Chunli family began to grow accordingly. In contrast to Zhandong, Chunli married four women. The first wife, Chen, died shortly after marriage without bearing any children. The second wife, $\mathrm{Wu}$, bore him five sons and two daughters. Then Chunli married Liang as a concubine who bore him another five sons and one daughter. The eldest, second, fourth, sixth, and eighth sons belonged to $\mathrm{Wu}$, while the third, fifth, seventh, ninth, and tenth sons belonged to Liang. When Wu died, Chunli married Yuan and gave her status as a wife rather than a concubine. When Chunli married Yuan, he was almost sixty years old, while Yuan was only nineteen. Chunli granted Yuan a wife status for fear that she would not agree to this marriage as a concubine due to the age gap. Yuan bore him another two sons and three daughters, including Yitang (1866-1952), who was the eleventh son of Chunli. Through marriage to four women, Chunli had twelve sons and six daughters in total.

In Chinese family culture, the idea of filial piety includes proper marriage and having sons to continue the family line. As Mencius said, having no male heir was the worst of three offences against filial piety (bu xiao you san, wu hou wei da 不孝有三, 无后为大). It was not uncommon for Chunli to marry four wives and have eighteen children as a wealthy man in traditional Chinese society. Different from his father, Chunli wanted to establish a large family, as a large family could expand into a large lineage. Since the late seventeenth century, lineage organizations proliferated in Guangdong due to the social unrest. Bandits sometimes attacked the villagers during the harvest time. Armed feuds between Cantonese and Hakka over land disputes were common. There were also frequent physical fights over property between rival lineages or tenants' rebellions against rent collection. The lineage system was so prevalent that most rural inhabitants belonged to one or two lineages in that area. ${ }^{26}$ As endemic violence was part of rural life in Guangdong, a large family or a strong lineage organization was a reliable safeguard against bullying, looting, or bandit attacks.

\section{Education and Ancestral Hall as Symbol of Success}

As a wealthy man, Chunli sought to elevate his family's status by building an ancestor hall. Building ancestral halls reflected ancestor worshipping in Chinese culture. In rural Guangdong, however, ancestral halls were far more numerous than other provinces. As Qu Dajun observed in the 1690s, "Every clan, big or small, have ancestral halls built in grand style and which function as lecture rooms. A clan of one thousand people could have several dozen ancestral halls". ${ }^{27}$ Beginning in the seventeenth century, ancestral halls proliferated across the province. A shortage of arable land, commercial farming, and social instability all contributed to the growth of clan organizations. Building ancestral halls reflected the importance of the lineage organization in rural Guangdong. Chen Hansheng noted that one village of about seven hundred inhabitants in Guangdong maintained over forty ancestral halls, though they belonged to one huge clan. ${ }^{28}$ Wealthy and powerful families placed memorial tablets of their ancestors in it. The ancestor usually belonged to the lineage or the clan.

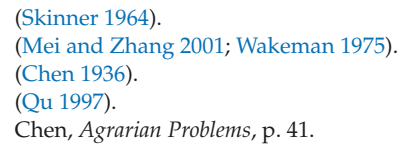


Tablets in the family shrine could be preserved for at least four generations. In Chunli's time, building ancestral halls displayed the wealth and social status of a family.

Similar to other wealthy families, Chunli invested in his children's education. The ancestor hall that Chunli built also functioned as a school named cuncheng shushi (Preserving Sincerity Study House). The village had four ancestral halls and all of them were used as schools. There were numerous village schools in Guangdong Province during the late Qing period. Cuncheng shushi was a school for the Chung lineage but open to other children in the village as well if they paid tuition. Having an ancestral hall and a school meant the Chung family became influential in the village affairs, with Chunli as the family head. After attending a village school such as the Chung family's cuncheng shushi, some gifted children of an ordinary family could go to more advanced schools called shuyuan (academic institute), located in towns and cities, and take a local civil service examination. The shuyuan system began in the Tang Dynasty as a private education institute and became popular in the Song Dynasty (960-1275). Guangdong had many shuyuan by the 19th century. ${ }^{29}$ Education was an important channel for social mobility in China because of the civil service system. Chunli invited local scholars to teach at his school in the hope that his children could pass the local civil service examinations and become government officials. Village schools could not guarantee the success of every student. Most students probably dropped school to pursue other possibilities of livelihood, but many rural children were able to obtain functional literacy.

Through the civil service examinations, educated men could earn scholarly titles of three levels—xiu cai (秀才), ju ren (举人), and jin shi (进士). The highest title was jin shi, which almost guaranteed a position in the government. Ju ren ranked second and was eligible for government positions at the provincial level. Xiu cai was the third, and may or may not get a government position. ${ }^{30}$ As Confucius said, good education leads to officialdom. Among Chunli's children, his eldest, second, third, fourth, fifth, and sixth sons passed the preliminary county test (xiang kao 乡考). Biaobing, his eldest son, became a bingsheng (禀生), the paid xiu cai licentiate, while others became fushen (副生), the supplementary licentiates without pay. Bingsheng was the first place winner in a local preliminary county test and was eligible for a position in the local government, and received a government stipend before his appointment. As a bingsheng, Chunli's eldest son became an education official in Shunde County, a neighboring county to Kaiping. As historian Wakeman observed, "The Canton basin was one of the most academically prestigious areas of the country. During the Ch'ing period, Kuang-chou Fu ranked fifth among the nation's prefectures in the number of chin-shih (Kuang-chou Fu is Canton and chin-shih is jinshi)". ${ }^{31}$

Family life reflected Chinese social structure. With scholarly titles, sons of Chunli brought honor and prestige to the Chung family. Even without being a government official, they made the Chung family part of the gentry class in Chinese society. A family of gentry class was exempted from local taxes, public manual labor, and corporal punishment in court. The local government respected the gentry families and treated them as community leaders. ${ }^{32}$ Through schooling at shushi and shuyuan, people from ordinary families could change their class status. Education in traditional China led to prestige, power, and wealth. Susan Mann defines the family system, civil service examination system, and patterns of male sojourning as three grand social structures that impacted human actions in traditional Chinese society. ${ }^{33}$ Early Chinese immigrants were mostly Cantonese and their community leaders were often holders of scholarly titles. Of the fourteen presidents from 1881 to 1927, the Sanyi Association, the largest Cantonese immigrant organization, had three jinshi, nine juren, and one gongsheng. By 1906, the Six Companies, an umbrella organization for all Chinese immigrants in America, had had four

29 (Grimm 1977; Hsiao 1960; Liu 1958).

30 For in-depth discussions on the civil service examination, see (Ho 2000).

31 Wakeman, Social Disorder, p. 181; Liu Boji, Guangdong shuyuan zhiduo, pp. 46-78.

32 (Zhang 1955).

33 (Mann 2000). 
juren as president. ${ }^{34}$ Some of those degree holders were probably merchants as well, and could have purchased their degree titles. In the late 19th century, wealthy families in China began to purchase scholarly titles when the declining Qing government permitted such purchases. The civil service examination system officially stopped in 1905.

\section{Sibling Feuds over Family Property}

Though family wealth reached its zenith during Chunli's generation, it began to decline when he was getting old and needed to divide family property among his sons. Chinese family culture disapproved of primogeniture. Every son was entitled to a share of the family property following the principle of equal inheritance among sons. According to Qing codes, even a son born of a proscribed sexual relationship, such as with a domestic maid, would receive half the share of a legitimate son. The father could not disinherit a son without a valid reason. ${ }^{35}$ One of the most common legal contracts in the late Qing Dynasty was the contract for family property division. In splitting family wealth, the rule of equal inheritance ensured that brothers were equal. All sons, whether they were the offspring of the primary legal wife or concubines, had rights in the patrimonial estate and property, as long as their father recognized them as sons. Chunli had twelve sons. As a competing sibling for family property, Yitang was much younger than most of his elder brothers. To make sure he could get his share of family property, his mother Yuan arranged for him to marry young. As Japanese historian Tadashi Fukutaku put it, "property division may take place either before or after the death of the father but generally occurs at the time of the marriages of the second and third sons, as harmonious family life is difficult to maintain when married brothers live together". ${ }^{36}$ In the Chung family's case, Chunli wanted to make sure that Yitang and his youngest son could receive an equal share of his property.

In 1882, Yitang married a girl named Guan from Langxia xiang, Kaiping County, when he was only sixteen years old. Guan bore Yitang three sons: Sam (Weixi), Zhongping (Weizong), and Elbert (Weiying) ${ }^{37}$ Yitang married young because he could not wait any longer, as Chunli was already seventy-seven years old. Some of Chunli's sons began to challenge his patriarchal authority. On one occasion, Chunli had a birthday dinner and his second son prepared his favorite food-a sea cucumber dish. When Chunli gave a piece of cucumber to Yitang, the second brother shouted at him: "This delicacy is a special food for you. Not for anyone else. You cannot give it away!" On another occasion, Yitang had a fight with a son of the second brother in school and slightly injured the head of his nephew with a wooden slipper. In revenge, the second brother chased him everywhere and wanted to beat him to death until Chunli interfered. ${ }^{38}$ Chinese family politics were delicate yet intensive. On the surface, the second son was competing for Chunli's affection and favoritism. In reality, he challenged Chunli's patriarchal authority, tried to enforce a hierarchical sibling relationship, and showed his power in family affairs. The first and second sons were rude to Chunli whenever they found him showing affection to the sons of his youngest wife.

After marriage, Yitang could have a house with its own kitchen (or stove), which marked independence. More importantly, Yitang could officially demand his share of family property and be treated as an adult member of the extended family. Chunli intended to divide his property evenly among his sons. According to a local practice, he could also have a share to the ratio of six-tenths to the son or sons of the primary wife, and four-tenths to the sons of concubines. Chunli's eldest and second eldest sons opposed this decision and wanted to maintain the land property in the name of the Chung lineage ownership. They were both degree holders and the most powerful brothers in the

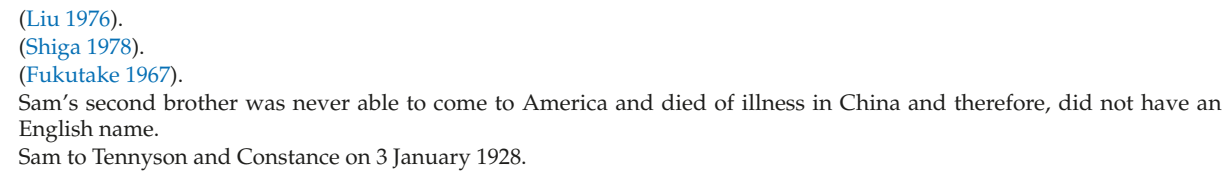


family. In Guangdong, some families or clans owned and managed land property this way due to the scarcity of arable land. The two eldest brothers wanted to control the entire farming property of the family in this type of ownership. Chunli insisted that one portion of his farming property be divided to each son and his family as a base to supply staple food. He passed away two years after Yitang's marriage and failed to solve his property division issue before his death.

After Chunli's death, the family conflict intensified. The second eldest brother sometimes physically attacked Yitang and his mother when feuds arose. On one occasion, there was no food left in Yitang's house as the two eldest brothers ordered the tenant farmers not to give any grain to them. As the family was starving, Yuan went to the farmland allocated to them by Chunli and cut the crop herself. When the second eldest brother heard this, he led a dozen of his family members and relatives to rush to the field and beat Yuan with bamboo sticks. Sam described the incident in a letter, "After they beat Yuan with bamboo sticks, there was blood all over her. Then they shouted that it was useless to kill this woman. Let us get rid of her son. The second eldest brother chased Yitang with knives in both hands. Yitang ran as fast as he could. He fled to a small hill, tried to jump over a pond on his way and then rolled down the hill, and lost consciousness. Someone later discovered and saved him". ${ }^{39}$

The physical attack on Yitang showed how brutal a family feud could be in Chinese society. Professor Ping-ti Ho pointed out that the custom of equal inheritance in Chinese society frequently gave rise to property disputes among brothers. Widows with minor sons often found it impossible to ward off the encroachment of rapacious brothers-in-law or other kinsmen. Ho cited an example in which a boy was thrown into the river by his uncle and was only later saved by a neighbor. ${ }^{40}$ Though Yitang narrowly escaped being lynched, the battle for family property became increasingly intense. Yitang and the other eight brothers formed a united front and called themselves the Nine Families, while the second eldest brother banded with the eldest and seventh brothers as the Three Families. The Chung brothers did not necessarily bind each other according to their maternal ancestors. The Nine Families shared a similar vision on how to divide family property. Their ultimate goal was to divide the family property evenly and get their share for their nuclear family. In general, it was the nuclear family rather than the extended family that was the preferred unit of consumption, production, and property ownership in Chinese society. Equal inheritance of family property among male heirs reflected that tradition. The Three Families wanted to control the entire family property themselves because the shortage of arable land in Guangdong allowed ownership of land under an extended family or a clan.

Male siblings' competition over family property demonstrated an inner contradiction in the Chinese family system. On the one hand, brothers had an equal claim to the assets of their family. According to the Qing law, all male descendants had the right to inherit a share of family property in land, houses, movable property such as furniture, clothing, livestock, and so on. On the other hand, male siblings were not equal in their family status. In the Chung family, for example, the eldest brother and second brother had more say in family affairs because they passed the civil service examinations and held scholarly titles. In Chinese family culture, as mentioned before, filial piety included the "ti" principle. Younger brothers were supposed to display obedience to older brothers, sometimes to the same degree as they did to their father. As an old saying goes, the eldest brother is similar to a father (zhang xiong ru fu 长兄如父). The Qing law coded that killing an older sibling deserved beheading. When older siblings killed younger siblings, the penalty was penal servitude or banishment. ${ }^{41}$ Such law could encourage elder brothers to abuse the "ti" principle and use physical assault in family feuds. Equal inheritance theoretically gave every male heir an equal share of family property, but in certain cases elder brothers could use the "ti" principle to their advantage. This contradiction in Chinese family culture made male sibling relationship a complicated issue in family politics. Dispute over the

39 Sam's letter to Tennyson and Constance on 3 January 1928.

40 Ho, The Ladder of Success in Imperial China, pp. 164, 302.

41 (Anonymity 1964). 
division of property, clashes over the support and treatment of parents, and abusive behavior by elder brothers could fragment a well-to-do family when an aging father lost his patriarchal authority in family affairs.

After Chunli's death, the Chung family declined rapidly. In a letter to his cousins, Sam wrote:

"Our marriage tradition is very different from the Western people. In the West, even if you have a millionaire father, you will not marry until you acquire a career to support yourself. The parents do not give money to children to encourage early marriage. After marriage, children and parents live in separate houses so that family conflicts are few. In our country, parents encourage their children to marry early. They do not care if they have enough food to feed the family but are only interested in having grandsons to show off. Life in a Chinese extended family is similar to hell. The rich, big families only produce parasites for the human world. Our ancestor Chunli's family is a case in point. Each son received two hundred dan of grain per year for his nuclear family. When the grain was processed into food, there was about one hundred and twenty dan left and forty dan of grain had to feed domestic animals. So each family only had eighty dan left. If one dan was worth two dollars, each family had about one hundred and sixty dollars a year. The children's education cost about thirty dollars; clothing thirty dollars; social activities twenty dollars; and medicine twenty dollars. They had very little money left. Yet many of our extended family members lived a befuddled life, only interested in getting concubines, opium-smoking, and gambling" ${ }^{4}$

Due to the family feuds, several siblings escaped to Canton (Guangzhou) with their spouses and children. Two of Yitang's sisters died of hunger, as daughters could not inherit family property. In his letters, Sam mentioned that some children and grandchildren of Chunli lived a parasitic life, gambling, smoking opium, and interested in having concubines. ${ }^{43}$ Sam concluded that Chunli was not happy in his senior years, although he earned four-thousand dan of grain annually, had eighteen children, and lived until seventy-nine years old. ${ }^{44}$

\section{Migration to America}

Yitang Chung and Sam also left their village to live in Canton. Both of them knew herbal medicine and further studied it to become practitioners. Yitang opened a medical office in the city, while Sam attended modern schools to adapt himself to the changing Chinese society. In a letter, Sam wrote: "I studied business for one year in Hong Kong, where they only taught me some mathematics and English. Then I studied at the Guangdong Police Academy for two years. I also studied Chinese traditional medicine. After working for the government, I have been very busy and have had little time to read books". ${ }^{45}$ Sam became a learned man. While widely read in Chinese classics, such as Confucian teaching or Tang poetry, in addition to writing classic poems himself, he also had strong interests in the writings and ideas of radical and reformist intellectuals of his time, such as Sun Yatsen, Kang Youwei, Liang Qichao or Hu Shi, Chen Duxiu, Cai Yuanpei, and translations of Western political and literary writings.

In 1900, Yitang migrated to the United States as an herbal doctor. During the Chinese exclusion period (1882-1943), an herbal doctor was a merchant in class status and eligible for admission. He established an herbal medical business in Los Angeles and remitted money to support his wife and three children in China. In the daytime, he mainly served the non-Chinese patients in his residence and office on Ninth Street. In the evening, he rented an office room above Tsui Fai Low Restaurant

\footnotetext{
Sam to Tennyson on 4 December 1928.

Sam to Tennyson on 4 December 1928.

Sam's letter to Tennyson and Constance on 3 January 1928.

Sam to Tennyson on 25 December 1921.
} 
in Chinatown. ${ }^{46}$ The Chinese population in Los Angeles was concentrated in two areas: Chinatown, next to the Plaza, and an area to the east of Adams Boulevard district. By 1910, while being a residential area for the Chinese, Chinatown had at least fifteen restaurants, many gift shops, grocery stores, herbalist offices, and Chinese organizations. The Chinese community in the East Adams Boulevard area gradually expanded to Ninth Street. Many Chinese farmers or farming laborers in the produce business lived there. ${ }^{47}$ After his wife passed away in China in 1908, Yitang married Nellie Yee (Yu), an American-born woman, on 2 June 1910. He was already forty-four years old, while Nellie was twenty-two. During this period, women only made up a small percentage of the Los Angeles Chinese community. The U.S. Census recorded 2455 men but only 147 women. ${ }^{48}$ Yitang was fortunate to be able to form a new family. Chinese Exclusion Laws made it very difficult for Chinese immigrants, even merchant class immigrants, to bring their wives and children to America. With a new family, Yitang's life in the United States became stable. Nellie bore him four children: Lillian (Qiaoxin or Kow San) on 31 March 1911, Arthur (Weixun or Wei Soon in Cantonese) on 31 December 1913, Marion (Qiaoshang or Kow Shung) on 8 October 1920. and Marie (Qiaozhuang or Kow Shung) on April 6, 1927. When the last two daughters were born, the family moved to 1322 South Hill Street. ${ }^{49}$

With income from the herbal business, Yitang invested in an asparagus farm of twenty-five acres in North Hollywood around 1915 in partnership with some relatives. When Sam arrived in the United States on a government mission that year, Yitang requested for him to stay and assist him in the family herbal and farming business. Sam practiced herbal medicine for a couple of years and then took over the management of his father's farm located at 4660 Whitsett Avenue in North Hollywood around 1918. Asparagus farming was a long-term investment and required sophisticated farming skill. Usually an asparagus farm could not produce a yield until the third year or longer. Harvesting first grade asparagus, a good laborer could cut only one acre per day. Under Sam's careful management, the farm began to yield asparagus in the third year. He became a master asparagus grower and could handle asparagus growing on both the rich soil and the sandy land. In addition to asparagus, he planted as many as a dozen other agricultural crops, including potatoes, sweet corn, hay, alfalfa, sweet potatoes, squash, pumpkin, watermelon, cabbage, and cauliflower. The family invested in a second farm in 1928. With their herbal store and farming business, Yitang and Sam managed to sponsor more than forty cousins, nephews, and other relatives to the United States in the following decades. ${ }^{50}$ The transnational voyage of Yitang and Sam was not an individual adventure but a family-oriented relocation, with kinship relationship as a priority consideration.

\section{Names in Chinese Family Culture}

When Sam decided to stay in America, he had to re-establish his immigration status from a government visa to a merchant visa. He prepared numerous paperwork, went through several rounds of interrogation at the Immigration and Naturalization Service, and answered many questions. Many of the questions were about his family history. On November 6, 1923, Inspector J. C. Nardini and You Chung Hong, a then INS interpreter and later a well-known Chinese American immigration lawyer, interviewed him. Mr. Nardini began by asking Sam to list all of his Chinese names. Sam gave three: "Chang Wei, boyhood name; Chang Sue Yick, married name; and Chang Sheong Peoy, chosen name; no other names". ${ }^{51}$ In Chinese family culture, men could have several names-a given name in his nuclear family, a generational name used in the clan, or a nickname used by his parents and neighbors.

46 Nellie Chung Interview.

47 (Mason 1967; Cheng and Cheng 1984).

48 Cheng and Cheng, Chinese Women of Los Angeles, pp. 2-7.

49 Records of the INS-Los Angeles District Segregated Chinese Case Files, 1893-1935: 29160/141 \&142 (Box 358) at NARALN.

50 See Introduction Chapter of The Transnational History of a Chinese Family for the basic facts about the Chung family. They used both "Chang" and "Chung" in English spelling as their last name.

51 The Chung immigration files at the Records of the INS-Los Angeles District Segregated Chinese Case Files, 1893-1935: Files 5530/546 (Box 249) at NARALN. 
Sam's given name was "Chang Wee Chee" (Zhang Weixi in contemporary Romanization), which had already been used by two relatives in the early 1910s. One used Sam Chang's name and another used Yitang's second son Weizong's name (Chang Weizong or Cheung Tseng Gip,;2 Weizong never came to America and passed away in 1927). Sam could not use this name any more and could not stay in America as Yitang's son. In his immigration files, Sam was not a son but a business partner of Yitang. This was why he used "Chang Wei" instead of "Chung Wee Chee" as his given name in the interview. He also spelled "Chung" into "Chang". Sam eventually obtained his merchant status, was able to stay, and sponsored his family members. In the last round of interviews regarding Sam's merchant status, Nardini pointed to a photo of Sam and asked Yitang: "Who is that person?" Yitang replied briefly: "Chang Wei, my partner". The answer ended the interview and covered the father-and-son relationship in their immigration papers. Ever since then they were never be able to address each other as father and son in public. The coverage was a painful episode in the Chung family history. Both Yitang and Sam understood that passing Sam as "Chang Wei" in the testimony was crucial to the collective interest of the Chung family in America.

Naming was an important component in Chinese family culture. Multiple names reflected a Chinese man's generational status in his nuclear and extended family. Every one of Sam's names was meaningful in its own way. Yitang had four sons-three by his first wife and one by his second wife. As the eldest son, Sam's given name was "Weixi" and his three younger brothers were accordingly "Weizong", "Weiying", and "Weixun". In Chinese lineage culture, the word "Wei" represented Sam's generation in Yitang's nuclear family. In the interview, Sam gave "Chang Sue Yick" as his "married name". There was no such a thing as a "married name" in Chinese family culture. He put "Chang Sheong Peoy" (Zhang Xiangpei) as a "chosen name" in the interview, and there was no such a thing as "chosen name" in Chinese family culture. Sam or other immigrants probably created name categories that sounded familiar to INS officers rather than listing their names according to Chinese family culture. In the Chung extended family, Sam's clan name was "Xiangpei", with the last character "pei" indicating the rank of his generation. In the extended family, Sam shared the "pei" word with all his male cousins. In the Chung lineage history, Yitang's clan name is "Pengbing", with "bing" being shared by all male members of Yitang's generation. "Yitang" was a courtesy name used socially in the circles of his friends, acquaintances, or his profession. He could choose any words for his courtesy name. Sam's courtesy name was "Chang Sue Yick" (Siyi). He listed it as his "married name" in the immigration interviews. Sam used "Xiangpei" when he wrote letters to his fraternal cousins and uncles, "Weixi" when he wrote to his brothers, and "Siyi" when he wrote letters to friends and acquaintances, and as his penname when he wrote poems and recollections of his life. Yitang and Sam sponsored several dozen of their relatives to the United States. Sponsored relatives were supposed to work in the Chang family's herbal or farming business. One letter from Sam indicated several relatives had invested in the farm. One relative named Tianpei was eager to cash out his profits and return to China. ${ }^{53}$ As mentioned before, Sam shared the "pei" word with all his male cousins. "Tianpei" was obviously one of them.

Sam was married in 1904. His wife, Zhiyuan Cen, was born in 1885 to a wealthy family in Enping County. Coming from a rich family, Cen knew how to read and write and was able to write letters to her children when they were away from home. Sam and Cen's first child was born in China in 1910, named Tingxun, who came to America in 1929 and adopted "Tennyson" as his English name. Their second child was Yuhua, a daughter born in 1912, who was named Constance after she came to America in 1923 with her mother. Similar to many Chinese parents, Sam gave his children Chinese names. Sam's son Tennyson was Tingxun in his Chinese name, with "ting" as the word to indicate his generation rank in the Chung family. He shared this character with all his male cousins. Sam gave his daughter

52 Records of the INS-Los Angeles District Segregated Chinese Case Files, 1893-1935: 4935/6 (Box 108) at NARALN.

53 Ibid. 
the word "Yu" as a generation word in their Chinese names too. As mentioned before, Constance' Chinese name was "Yuhua". Sam's third daughter Estelle was "Yuchu" and his fourth daughter Joyce was "Yuchzai". "Yu" means jade in Chinese and is Yook in Cantonese Romanization. Yitang's American-born daughters had Chinese names too. When Lillian Wong, daughter of Yitang, composed a family tree of the Chung family, she lists both their English and Chinese names. ${ }^{54}$ A traditional genealogy book of a Chinese family would not list the given name of a female member, whether she was a wife or daughter.

\section{The Chung Family Become Transnational}

If equal inheritance tradition made the Chung lineage a divided house, Yitang's migration to America helped the lineage members to re-organize themselves around him. His sponsorship included sons or grandsons of those siblings who had bullied him in the past. He also helped several relatives who had been driven away from the home village by the family feuds. Yitang's migration and sponsorship of relatives to America made him a highly respectable person in his lineage and home village. Around 1916-1917, several members of the Chung lineage proposed to build an ancestry hall in Yitang's honor. The lineage collected money, purchased a piece of land, planted trees around it, and named it Huai Yuan (the Beholder Garden). Sam wrote a biographical sketch of Yitang engraved on the tablet in the hall that read:

Having heard that America was the wealthiest country in the world, father decided to go there alone. He did business there for three years and then came back to see his aging mother as a filial son. He also sent his children to modern schools and believed that only reforms could make China strong. Following his idea, Weixi attended the Advanced Police Academy of Guangdong, Weizong went to the Guangdong College of Law and Administration, Weiying to the medical school at Georgetown University, and Weixun and Qiaoxin graduated from Los Angeles High School in America. When father was thirty-eight, he returned to America. Up until now, he has been in America for sixteen years and has managed to bring twenty to thirty relatives to America. ${ }^{55}$

Sam listed migration, children's education, and sponsorship of relatives to America as three Yitang's great achievements. Family history reflected changes and continuities in Chinese society. In 1905, the Qing government ended the civil service examination system. In 1911, China became a Republic. As an immigrant, Yitang wanted his children to pursue opportunities in both China and America. Yitang's third son Weiying (Elbert) came to the United States when he was twelve years old. After graduating from Georgetown University Medical School, he could not find a job in America but received an offer as an intern physician in the prestigious Beijing (Peking) Union Medical College established by the Rockefeller Foundation in China. Weixun (Arthur) was born in America but went to Nankai University in Tianjin and Yanjing (Yenching) University in Beijing for his college education, and then National Medical College of Shanghai for his medical degree. He worked as an established physician in China until he returned to America in 1975. Yitang's American-born daughter Lillian (Qiaoixin) went to work in China after she graduated from the University of Southern California in 1933.

In 1928, Yitang returned to China for a visit. The Chung lineage treated him like a hero. Yitang "swept" the tomb of his father, donated money to build a new road for the village, and also made his ancestor hall a school for the Chung lineage children and children of the poor in the village. To have an ancestral hall built in his name was a great honor for Yitang. Only men of outstanding achievement or contribution to the lineage or clan deserved such an honor. Building an ancestral hall

54 See Liu, The Transnational History of a Chinese Family, p. 211.

55 The original draft of this biography is still preserved in the collection of Sam Chang family papers. 
for an outstanding member of the lineage was a core value in Chinese family culture and especially prevalent in Guangdong. Yitang's sponsorship of relatives from China to America earned him great respect from his lineage. Rather than breaking away from home, Yitang's migration strengthened his ties with his lineage and enabled the kinship network of the Chung family to transplant from China to the United States. Yitang was not an exception in earning respect from his relatives at home as a successful immigrant. When hundreds of thousand Cantonese migrated overseas, many of them remitted money home and sponsored relatives to join them in America. From the late 19th century and the early 20th century, many ancestral halls with tablets in honor of those immigrants appeared in rural Guangdong. As Frederic Wakemen points out, "These tablets actually conferred genuine social status to those enshrined there, and to their descendants who came to pay ritual respect" 56

Together with his father, Sam remitted money to the Chung family and lineage, contributed suggestions and opinions regarding the management of the lineage property, and co-sponsored relatives to come to America. Sam farmed for over fifty years on the family farms in Southern California. Though he sometimes wanted to explore other careers and often talked about returning to China, a strong sense of obligation to the Chung family made him a life-long asparagus farmer in America. The two farms under his management became a reliable resource of family income and provided job opportunities for immigrant relatives and friends. While busy with his asparagus farming, Sam kept a close eye on his children's education. Similar to his ancestors, Sam valued education and viewed his children's education as an important family agenda. In order to adapt to the changing China and the racial environment in America, he arranged his children to attend to schools in both China and America. He believed that English ability was a marketable skill for his children, though they could have a better career in China as educated Chinese.

Sam carefully planned his children's education. When getting his family members to America, Sam first sent for his wife Cen and daughter Constance but asked his son Tennyson to complete his high school education in China before coming to America. In a letter in 1922, Sam explained to Tennyson that he decided to send for Cen and Constance first because U.S. immigration laws had become tougher and tougher for Chinese. Some politicians even proposed a total ban of Asian immigrants. ${ }^{57}$ However, Sam advised his son: "If you want to be a person of high social status, America is not the right place for you. But if you want to make money to help your family out of temporary difficulties, no other country's money is worth more than the American dollar" ${ }^{58}$ He asked Tennyson to complete high school in China, improve his English language ability, get into a top-tier Chinese university, and then transfer into a top-tier American university. In a letter, he told his son: "You are now sixteen and should study hard to have a good command of Chinese before you come here to study English, which is not so difficult. No great scholar can write a good English article if his written Chinese is poor. ${ }^{59}$ He wanted his son to think of his future in China. Sam urged his son to study in a school where English training was competent and the first choice should be Qinghua College in Beijing, which sent hundreds of Chinese students to study abroad every year. When planning his children's education, Sam seemed to possess meticulous information about education in China. He wrote: "If you cannot apply to Qinghua in Beijing this July, try it next year. Now you have been at Tongzhi School for three years. You will graduate in one more year. You can apply to Qinghua after graduation. If you cannot get into Qinghua, apply to Lingnan. After graduation from Lingnan, try to get into Beijing University. Then you can apply to an American university. But this plan costs a lot of money and takes too much time". ${ }^{60}$ Then he wrote again: "Lingnan is a good English language training institution. You should be

\footnotetext{
56 Wakemen, Social Disorder in South China, p. 113.

57 Sam to Tennyson on 24 May 1922.

58 Ibid.

59 Sam to Tennyson. The letter has no date but seems to be written around 1925.

60 Sam to Tennyson on 25 December 1921
} 
able to pick up enough English there before you apply to Qinghua or Beijing University. Then you could apply to come to America". 61

As an immigrant parent, Sam knew that admission into a top tier university, such as Qinghua in Beijing or Nankai in Tianjin, would enable Tennyson to get a student visa when he was applying to an American university. Entering into the United States on a student visa was a lot easier than as an immigrant. Chinese exclusion laws did not ban the entry of students and U.S. immigration officers were more lenient when questioning student applicants. Sam told his son,

"You could apply for a visa directly from the American Counsel and be spared from complicated paper work and rough interrogation. You should apply to Qinghua College or study in Lingnan University. If you cannot get into Qinghua, you should try to get into Nankai University in Tianjin. Then you can come to America for a graduate school or as a transfer college student, which is the best plan for your education". ${ }^{62}$

Rather than an immigration scheme, Sam actually mapped out an ideal educational route for his son. An important goal in this route was to enter a good American university. Though Qinghua or Nankai in China could provide Tennyson an excellent modern education, a diploma from an American university was a necessary stepping stone to pursue a good career in China. As Rose Hum Lee notes, a more calculated plan for a Chinese family for its children's education in the early twentieth century included studying at missionary schools at an early age and later at institutions of higher learning that emphasized Western curricula. A good command of English from these schools paved the way for study abroad. The degree obtained in a foreign institution became the criterion for upward mobility and an established place in the Chinese social hierarchy. ${ }^{63}$

When advising Tennyson to leave Guangdong for North China, Sam provided specific instructions on how to travel from Guangdong to Beijing and Tianjin. In a letter of 1924, he wrote,

You should reserve your ship ticket through Hongfa or Tai-an Hotel. Around the departure, the hotel will contact you, tell you where to board the ship, and take you there. It will take three days from Canton to Shanghai. You can stay for one or two days in Shanghai at the Hongfa Hotel where Cantonese speakers are always available at your service. There are many swindlers in Shanghai. Most of the rickshaw men are thieves. You must be very careful. It will take four days from Shanghai to Tianjin by ship. Taida Company offers a reasonable ship ticket. It will probably cost twelve dollars to get to Tianjin. A member of the Chung lineage is a doctor in Tianjin but we do not have his address. You can stay in Tianjin for one day and take the train to Beijing the following day. You will arrive in Beijing at three o'clock in the afternoon. At the train station, there are many hotel agents. Choose Fuzhao Hotel and ask them to get you a rickshaw. The hotel is owned by Mr. Zhu of Qingyuan County of Guangdong and is located on Mule and Horse Market Avenues in Beijing. It will cost you sixty to seventy cents a day. After one or two weeks, you will be familiar with Beijing. Streets in Beijing, Tianjin, and Shanghai are much wider than streets in Canton and easier to locate. In Shanghai, British money is popular, while in Beijing and Tianjin, French and Japanese money are popular. ${ }^{64}$

After attending Nankai High School in Tianjin, Tingxun (Tennyson) came to America and earned a Bachelor's degree from the University of Southern California, a Master's degree from Columbia University, and a Ph.D. degree from Georgetown University. His first job was as a diplomat at the

61 Sam to Tennyson on 22 July 1922.

62 Sam to Tennyson on 27 April 1923.

63 Lee, The Chinese in the United States, p. 99.

64 Sam to Tennyson on 12 May 1924. 
Chinese embassy in Nicaragua. Sam's daughter Constance (Yuhua) was born in China and came to America in 1923. However, she returned to China four years later for her high school and college education. She did not come back to America until 1937. Sam's third daughter Estelle went to China when she was only eight years old and stayed there five years. By 1924, Sam had been away from China for nine years but his letter revealed an explicit knowledge about Shanghai, Beijing, and Tianjin. The most significant part of the letter is his description of Cantonese networks that could assist Tennyson to travel all the way from Canton through Shanghai to Tianjin and Beijing. Sam even knew the name of a Cantonese hotel owner in Beijing and his home district. Such knowledge informs us of how social networks of the Cantonese extended to metropolitan cities in East and North China and was available for traveling Cantonese if they needed local contract. Cantonese immigrants in North America had similar social networks.

This was a period when many Chinese American youth could not find jobs that matched their college education in America. ${ }^{65}$ Yitang and Sam did not hesitate to send their American-born or raised children back to China when racism blocked their children's career mobility in America. They worked hard in their herbal and asparagus businesses in order to provide a financial base for the younger generation to receive good education across the Pacific. In Chinese family culture, education was more than an individual ambition or personal interest but an important family agenda. Self-sacrifice of the parents, in return, obliged the younger generation to compete vigorously at school in order to pursue good careers for social mobility. Their educational success was not only an individual merit but represented the shared interest of a Chinese family. Instead of family collectivism giving way to individualism, we see compromise between personal goals and the greater good of the family as a collective. Sam's immigrant background, knowledge about China, and transnational world outlook assisted his children in exploring education and career opportunities in both China and America. Sam lived a long life and passed away in 1988 in Los Angeles at the age of 102 years old. One regret he had was that he never had a chance to return and visit his home country after his arrival in America in 1915. However, all of his children accomplished college education and became middle-class professionals. Transnational life and culture reflected not only the emotional attachment of Chinese immigrants to China. but also their aspiration for a better life and efforts to give more opportunities to their children.

Supplementary Materials: The following are available online at http://www.mdpi.com/2313-5778/3/3/46/s1.

Funding: This research received no external funding.

Conflicts of Interest: The author declares no conflicts of interest.

\section{References}

Anonymity. 1964. Daqing Luli Huitong Xinzuan [The Law of the Qing Dynasty. Taibei: Qing Court, vol. 4, p. 2795. Baker, Hugh D. R. 1979. Chinese and Kinship. London: The MaCmillan Press, p. 133.

Chen, Han-sheng. 1933. The Present Agrarian Problem in China. Shanghai: China Institute of Pacific Relations, p. 7. Chen, Hansheng. 1936. Landlord and Peasant in China. New York: International Publisher, p. 37.

Cheng, Lucie, and Suellen Cheng. 1984. Chinese Women of Los Angeles, A Social Historical Survey. In Linking Our Lives: Chinese American Women of Los Angeles. Los Angeles: Asian American Studies Center, University of California, Los Angeles and Chinese Historical Society of Southern California.

Faure, David. 1989. The Rural Economy of Pre-Liberation China: Trade Expansion and Peasant Livelihood in Jiangsu and Guangdong, 1870-1937. Hong Kong: Oxford University Press, p. 215.

Freedman, Maurice. 1958. Lineage Organization in Southeastern China. London: University of London, Athlone Press, p. 17.

65 I refer Yitang and Sam as the immigrant generation and their American-born, -raised, or -educated children as the younger or the second generation though they belong to a three-generation family history. 
Fukutake, Tadashi. 1967. Asian Rural Society: China, India, Japan. Seattle: University of Washington, p. 86.

Grimm, T. 1977. Academies and the Urban System in Kwangtung. In The City in Imperial China. Edited by G. Skinner. Stanford: Stanford University Press.

Hayes, James. 1982. Written Materials in the Village World. In Popular Culture in Late Imperial China. Edited by David Johnson, Andrew J. Nathan and Evelyn S. Rawski. Berkeley: University of California Press, p. 87.

Ho, Ping-ti. 1959. Studies on the Population of China, 1368-1953. Cambridge: Harvard University Press, p. 283.

Ho, Ping-ti. 1962. The Ladder of Success in Imperial China: Aspects of Social Mobility, 1368-1911. New York: Columbia University Press, p. 314.

Ho, Ping-ti. 2000. The Ladder of Success in Imperial China. In A Cultural History of Civil Examinations, in Late Imperial China. Edited by Benjamin A. Elman. Berkeley and Los Angeles: University of California Press.

Hsiao, King-Chuan. 1960. Rural China: Imperial Control in the Nineteenth Century. Seattle: University of Washington Press.

Kulp, Daniel Harrison, II. 1966. Country Life in South China: The Sociology of Familism-Phenix Village, Kwantung, China. Taibei: Cheng-Wen Publishing Co, p. 86f.

Liu, Boji (Pei Chi). 1958. Guangdong Shuyuan Zhiduo [System of Guangdong Academies]. Taibei: Taiwan Books.

Liu, Boji. 1976. Meiguo Huaqiao Shi (A History of the Chinese in the United States of America). Taibei: Commission of Overseas Chinese Affairs, Republic of China, pp. 174-75.

Liu, Haiming. 2005. The Transnational History of a Chinese Family. New Brunswick: Rutgers University Press, pp. 13-14.

Mann, Susan. 2000. The Male Bond in Chinese History and Culture. The American Historical Review 105: 1600-14. [CrossRef]

Marks, Robert B. 1984. Rural Revolution in South China: Peasants and the Making of History in Haifeng Country, 1570-1930. Madison: The University of Wisconsin Press, pp. 54-64.

Mason, William. 1967. The Chinese in Los Angeles. Museum Alliance Quarterly 6: 20-28.

Mazumda, Sucheta. 1998. Sugar and Society in China: Peasants, Technology, and the World Market. Cambridge: Harvard University Press, p. 54.

Mei, Weiqiang, and Guoxiong Zhang, eds. 2001. Wuyi huaqiao huaren shi [A History of Overseas Chinese in the Five Districts]. Guangzhou: Guandong gaodeng jiaoyu chubanshe, p. 29.

Parker, E. H. 1901. John Chinaman and a Few Others. London: John Murray, p. 70.

Qu, Dajun. 1997. Guangdong Xinyu [New Things in Guangdong]. Beijing: Zhonghua shuju, p. 464.

Shiga, Shuzo. 1978. Family Property and the Law of Inheritance in Traditional China. In Chinese Family Law and Social Change. Edited by David Buxbaum. Seattle: University of Washington Press.

Skinner, William. 1964. Marketing and Social Structure in China, Part 1. Journal of Asian Studies 1: 34.

Skinner, G. William. 1971. Chinese Peasants and the Closed Community: An Open and Shut Case. Comparative Studies in Society and History 13: 270-81. [CrossRef]

Takaki, Ronald. 1998. A History of Asian Americans: Strangers from a Different Shore. New York: Little, Brown and Company, p. 33.

Wakeman, Frederic, Jr. 1966. Strangers at the Gate: Social Disorder in South China, 1839-1861. Berkeley: University of California Press, p. 180.

Wakeman, Frederic, Jr. 1975. The Fall of Imperial China. New York: The Free Press, p. 14.

Yang, Wanxiu, and Zhuo'an Zhong. 1996. Guangzhou jianshi [A Concise History of Guangzhou]. Guangzhou: Guangdong renmin chubanshe, pp. 170-72.

Zhang, Zhongli. 1955. The Chinese Gentry; Studies on Their Role in Nineteenth-Century Chinese Society. Seattle: University of Washington Press.

(C) 2019 by the author. Licensee MDPI, Basel, Switzerland. This article is an open access article distributed under the terms and conditions of the Creative Commons Attribution (CC BY) license (http://creativecommons.org/licenses/by/4.0/). 


\title{
"I Have an Accent in Every Language I Speak!": Shadow History of One Chinese Family's Multigenerational Transnational Migrations
}

\author{
Jenny Banh $1 D$ \\ Department of Anthropology and Asian American Studies, California State University, Fresno, Fresno, \\ CA 93740, USA; jenbanh@mail.fresnostate.edu
}

Received: 25 March 2019; Accepted: 28 June 2019; Published: 1 July 2019

\begin{abstract}
According to scholar and Professor Wang Gungwu, there are three categories of Chinese overseas documents: formal (archive), practical (print media), and expressive (migrant writings such as poetry). This non-fiction creative essay documents what Edna Bonacich describes as an "middleman minority" family and how we have migrated to four different nation-city states in four generations. Our double minority status in one country where we were discriminated against helped us psychologically survive in another country. My family history ultimately exemplifies the unique position "middleman minority" families have in the countries they migrate to and how the resulting discrimination that often accompanies this position can work as a psychological advantage when going to a new country. We also used our cultural capital to survive in each new country. In particular, this narrative highlights the lasting psychological effects of the transnational migration on future generations. There is a wall of shame, fear, and traumas in my family's migration story that still pervades today. My family deals with everything with silence, obfuscation, and anger. It has taken me twenty years to recollect a story so my own descendants can know where we came from. Thus, this is a shadow history that will add to the literature on Sino-Southeast Asian migration and remigration out to the United States. Specifically, my family's migration began with my grandfather leaving Guangdong, China to Saigon, Vietnam (1935), to Hong Kong, (1969) (then a British Colony), and eventually to the United States (1975). This article explains why my family migrated multiple times across multiple generations before eventually ending up in California. Professor Wang urges librarians, archivists, and scholars to document and preserve the Chinese migrants' expressive desires of migrant experiences and this expressive memoir piece answers that call.
\end{abstract}

Keywords: transnational; migration; Chinese; food genealogy; identity; restaurants

\section{Prologue}

Maxine Hong Kingston starts The Women Warrior with the line, "You must not tell anyone ... what I am about to tell you." (Kingston 1975). On the surface, Kingston's warning is a simple prelude to the disclosure of family secrets; however, her warning also hints at the liberatory power of bearing witness to family history. In that vein, here is my own four-generation clandestine story. My mother also told me not to tell anyone but my marrow screams inside me. I have to write to stop the screaming of both my ancestors and my future descendants.

There is a traditional Chinese belief that says time is not a straight line but instead a circle, like the seasons, and the winds (De Mente 2009; Lipner 2012). ${ }^{1}$ Thus, poems are written for the reader

1 Hindus also believe in circular time. See Das, Subhamoy. "The Concept of Time in Hinduism." Learn Religions. https://www.learnreligions.com/the-concept-of-time-1770059 (accessed on 30 June 2019). 
1000 years in the future or 1000 years from the past. ${ }^{2}$ You can change your past with your poems. I would like to use this essay to save my grandfather. I do hope this letter goes back to my ancestors or ahead to my descendants to tell them I remember them. Viet Nguyen argues that descendants of refugees hold their ancestor traumas in their marrow (Bui 2017) ${ }^{3}$. But am I a refugee from 1000 years ago (or is it 1000 years in the future?). What I know for certain, is that my family transnationally migrated in multiple generations. Sometimes, it was under their own volition and sometimes we fled before the wars engulfed our family. Many of us did not make it, but we survivors did. We are a runner family and we have run for four-generations straight. This is simply one transnational migration story out of millions and I am aware many did not make it out alive.

According to Professor Wang Gungwu, there are three categories of Chinese overseas documents: formal (archive), practical (print media), and expressive (migrant writings such as poetry) (Wang 2002).

\section{Eight-Year-Old Girl}

When I was an eight-year-old kid in Bellevue, Illinois, my eighth-grade-educated father would tell me, "We get treated bad in this place but not as bad as African Americans." My father was not a Marxist or intersectional theorist but he conveyed to me the strange position my Chinese family held in black-and-white Midwest America. We owned a Chinese restaurant that catered to the local working-class population; consequently, we endured the usual racist comments or gestures one would expect given that our four-person family was an island of Chineseness in an ocean of non-Asians. These comments made me think I was a racial minority, but I also had psychological privileges of resilience. Only decades later did I realize that my family occupied what Edna Bonacich calls the "ethnic middlemen" class (Bonacich 1973). Ethnic middlemen are all over the world and often occupy an intermediate status rather than the lowest status. This group tends to concentrate in commerce and trade (Bonacich 1973). Jews in Europe, Chinese in Southeast (SE) Asia, Asians in East Africa, Japanese and Greeks in the United States, etc., are all examples of ethnic middlemen (Bonacich 1973).

Ethnic middlemen are positioned between the consumer and the buyer. Karl Marx called this group Petite Bourgeoisie defined as small-scale traders and shop keepers who manage production (Marx and Engels [1848] 2019). He views this group as predatory and an instrument of oppression (Marx and Engels [1848] 2019). There has been a lot of historical examples of backlash against these groups from the local populations (Anderson and Anderson 2012). In a world where the masses have little to no opportunities to express their anger against the owners of corporations, ethnic middle man families like mine often bear the brunt of that anger due to the perception of success despite the reality of struggle. Maybe the local population enmity was warranted but I will never know as I was not there. I do not want to get into an oppression Olympics discussion of who was the most mistreated (Hancock 2013). My larger point is that my family occupied a class position that made them despised, but that gave them a cognitive advantage when going to another country where they may also be discriminated against. My family had to transnationally migrate (or run) in each of the last four generations.

Because of the running, each generation had to leave everything behind and start anew with nothing in the new country. Although we did not have economic means, we had psychological bridges in our ancestral blood that we could access in times of need. These psychological privileges have accumulated intergenerationally and are found in my blood. I am not sure of the accuracy of my story because there are so many silent gaps, closed doors and intentional obfuscations from different family members.

2 There are some Chinese people who mark time by decades or generations and not by days. It is well circulated that the Chinese believe they have a five-thousand-year history.

3 See Viet Thanh Nguyen review of Thi Bui (2017). graphic novel The Best We Could Do. 


\section{1915 Guangdong, China}

Yéye 爷爷 (grandfather), who are you? We can never talk about you as Bàba 爸爸(dad) gets too sad or angry. Baba furiously in Cantonese says, "Don't ever talk about this sad time!" Your life and death created a crater of sadness so big that even three later generations could not fill it. Our family is a sad family and we were always taught to endure, ignore, and run if need be. We rarely laughed as a family and there was a lot of yelling, followed by a long enduring silence. We are a pessimistic family always expecting the worst and predicting downfalls. We trust no one unless they are ethnically Chinese and then, only slightly. We do not even trust each other in our family. In high school, I once (I am not proud of this now) read my jiejie's 姐姐 (older sister) diary and I saw that she wrote letters to you. She met you when she was only a baby. We heard you loved her so much and wanted to keep her in Vietnam but dad did not allow it because of the war. I do not remember what she wrote, but I remember I cried when I read it. I have never met you but you lurk in my blood. It makes me cry still when I think how everything you built was taken away. I know you died the year after you had to give up your companies to the Communists. We have never spoken of how you passed in our family and so this is just a shadow memory of you.

My grandfather was originally from Three Rivers Guangdong, China and moved to Saigon, Vietnam in his late teens. He was part of the historical flow of ethnic Chinese people moving into SE Asia for centuries (Pan 1998; Desai 2009). Grandfather's father and grandfather were turnip farmers. Yeye was born in 1915, Guangdong, China-a politically fractured time in Chinese history. There was much starvation, and death as there was not enough food for everyone (Chee-Beng 2013; Pan 1998). This is one of the reasons my grandfather had to leave China to make a better living. The push factors of out migration were political instability, poverty, and lack of opportunities. The pull factors of SE Asia were that other ethnic Chinese seemed to be making a better living than inside Mainland China. Yeye's uncle decided to travel to Vietnam and needed someone to be his accountant as "he did not trust the local Vietnamese people." Here I want to reckon and acknowledge these "cultural imperialistic" sentiments ${ }^{4}$; in other words, ethnic middlemen are not pure victims. At times, they can use their privilege to the detriment $t^{5}$ of the local populations ${ }^{6}$.

\section{Cultural Imperialism and Settler Colonialism}

Edward Said's book Orientalism (1978) goes over the patronizing way that the West has treated and depicted the Orient and its inhabitants for centuries. He defines the Orient as the Middle East, Asia and North Africa which are the source of the Occident's oldest colonies. Orientalism refers to ideas of the Orient's inferiority as an (1) academic field, (2) world view, and (3) political justification for domination (Said 1979). Said asserts that the West uses the Orient as an imaginary to juxtapose and define itself. For example, the Occident defines itself as rational and forward thinking while it relegates the Orient as irrational and backwards. You can see egregious example of Orientalism or western superiority over the east in western art, literature and governing.

Within Asia, there is also cultural imperialistic sentiments such as China viewing itself as superior to other Asian countries. China is named the "Middle Kingdom" so they often will view themselves as the center of the earth and other non-Chinese as aliens. In Cantonese, there are pejorative terms to call non-Chinese, such as "gzwái".

4 I would never say this to anyone in my family as it would illicit a huge argument as they tend to view themselves as pure victims. This is similar to how modern Westerners cannot acknowledge that they benefit every day from the social injustice of the past.

5 I have no knowledge that my family ever used their privilege to the detriment of the community. It was just an academic point that because of their class position there can be potential for inequities.

6 Not everyone can travel from country to country so my grandfather must have had some sort of privilege. This is where my familial life and academic training conflict with each other. 
Although it does not fit exactly, one can argue that ethnic Chinese who traveled to SE Asia had culturally imperialistic attitudes and practiced a form of settler colonialism. Settler colonialism is a form of settlement where the invading group replaces the local population. The British are the best examples of these as their inhabitants have slowly replaced the local population in the United States. The ethnic Chinese did not replace the indigenous Southeast Asians, but they used their Sino-networks to establish businesses and interacted and "trusted" only other ethnic Chinese. This created a closed Cantonese loop, and considerable resentment by the indigenous Vietnamese populations. I see settler colonialism ideas and attitudes in my family in that they tend to compare country to country in how well the Chinese can do business there.

There are examples of Chinese in SE Asian countries, such as Indonesia who have experienced murder and molestations by the local inhabitant when the economy was in a downturn (Osman and Hayanto 2010). In total, 50\% of the Chinese community in Cambodia were killed by the Khmer Rouge due to economic resentment and cultural problems. ${ }^{7}$ My larger point here is that these closed Chinese business circles can build up a lot of resentment in indigenous communities that they settled in. They can be easily scapegoated for all the supposed wrongs within the country.

\section{1935 Saigon, Vietnam}

In Vietnam, I imagine my grandfather experienced cultural shock while hearing a different language and seeing a drastically different people. He was a stranger, an immigrant, a flaneur in this new country of Vietnam. I am certain his goal was to return to China after he made money. In this sense, grandfather is no different from the other Chinese males of the diaspora, who go abroad, but have dreams of returning home as success stories (Takaki 1989; Pan 1998). They endure racism—or prejudice in this case-for the benefit of their future descendants. Sometimes, they take a local wife but not my grandfather. He had Chineseness in his soul. ${ }^{8}$ Did he pass that on to me? Can someone hold five thousand years of Chinese culture in her body through their food or language?

After he became economically successful, he travelled back to China to find a wife. There, he was "matched" with my spoiled 16-year-old grandmother. Her father (my great grandfather) married an additional wife so that he could produce a male heir, but that never happened. Thus, she had two mothers and a father who doted on her as an only child. It was customary for the upper classes to bind the feet of their daughters, but their family refused to disable her in this way (Shepherd 2019). I am so proud of these ancestors that they defied the common culture and would not bind my grandmother's feet. Though I must say she had tiny feet and hands that she has seemingly passed on to my daughter.

My grandfather worked and worked; as family folklore has it, that work ethic allowed him to establish multiple businesses that flourished in what would become Vietnam. Family lore also points out that he never had a mistress, something of a rare feat for a wealthy man of his generation. My other maternal grandfather cannot say the same; he had many mistresses. But this piece is not about my mother's side of the family. My grandfather owned a steel warehouse something equivalent to a US Home Depot warehouse store in the United States. Here, he sold supplies such as steel for different construction projects.

Tellingly, family lore speaks less of my MaMa (Grandmother) who bore all eight children (six sons and two daughters, including my father who is the second oldest son) in Vietnam. There were babies that did not survive but these are family traumas that would receive silences if you ask anything about it. She worked equally hard to manage the family.

To maintain the Sino-identity, my grandfather insisted on hiring a Chinese nanny for each of his Vietnam-born children despite it being more expensive than having a local Vietnamese nanny. Arjun

7 See (Gellately and Kiernan 2003) and (Vickery 1984).

8 I connect "Chineseness" with taking a Chinese wife to contrast with the many Chinese males in the diaspora who often took a second local wife. They would have a first family in Mainland China and a second family in the new land. 
Appadurai's Translocalities and Ethnoscapes are apropos here. He defines Ethnoscapes as a framework to see that the nation is not just tightly bound borders, but instead fluid cultural pathways. Ethnoscapes are discrepancies, meaning they are illegible spaces (Appadurai 1996). People such as tourists, immigrants, refugees, ethnic middlemen, and other people on the run form this scape (Appadurai 1996). These groups are in a perpetual mental and physical Translocality a "between-betwixt" state. They sometimes hold a culture like my family did that no longer exists (as, for instance, 1915 Guangdong, China). Did it ever? There are a connectivity and change and these groups are always considered marginal and lost in the official history books since no one claims them. My Sino-Vietnamese family were refugees that you cannot clearly define.

It is important to note that the entire family at this time still had Chinese citizenship. When my 84-year-old aunt was a teenager, the Vietnam government issued an edict that in order to keep your businesses and stay in the country you had to become Vietnamese citizens. My father and the entire family at this point all got Vietnamese citizenship while staying culturally Chinese. Aiwha Ong's Flexible Citizenship recounts how many Chinese overseas have multiple passports in many different countries. My grandfather used his economic privilege to send his kids to Chinese schools, not local Vietnamese schools. Thus, my father and his siblings (my aunts and uncles) grew up in a Cantonese bubble "sheltered" from Vietnamese influences. You can see here that the family pride (or excessive jingoism) in Chinese culture also masked their detachment from the local culture.

Where my father's side of the family was characterized by ethnic isolation and cultural retention, my mother's side of the family was more middle class and was more likely to interact, and even blend, with Vietnamese culture. To this day, Vietnamese is more the lingua franca for my mother's younger siblings. Some of my mother's younger sisters settled in Orange County, CA-the largest Vietnamese community outside of Vietnam - and almost exclusively speak Vietnamese; if they speak Cantonese it is with a Vietnamese accent. Some members of this side of the family have intermarried with Vietnamese nationals. My father has long been frustrated when he sees Sino-Chinese who no longer speak Cantonese.

Monica Trieu says her family is "publicly Vietnamese" but privately Chinese meaning they tell people they are Vietnamese but at home they identify as Chinese. (Trieu 2009)

To my surprise, some of my cousins were raised in Orange County, CA, and identify as Vietnamese which I find shocking. The Communist Vietnamese government nationalized all businesses and my grandparents had to give up their house and businesses. My grandmother in a last act of rebellion threw the keys of her four-story house into the ocean. All their children were sent abroad years earlier to avoid forced military enlistment. The family urged my grandparents to leave but they had spent a lifetime building up their businesses and my grandfather refused. My grandfather died of cancer shortly after having learned that he would have to give up his businesses. Did he die of a broken spirit? My grandfather's death seemed to suck all the happiness out of our branch of the family and we just went into survival mode, traveling from a nation state to a city state to another nation state. To this day, we are not a happy family, but instead a stoic and ascetic family, patriarchally run by my father. He would constantly tell us that women are incompetent. Fate bestowed my misogynist father with only two daughters, that he raised like sons. This is an example of how our family was battered by not just nation state policies, but also battered within the family.

\section{My Mother? A Silent Being That Loves Me}

I once read a graphic novel called, Are You My Mother? by Alison Bechdel (2013) and unequivocally I knew exactly what the title meant. It meant a daughter who never knew her mother. My mother has been at my side throughout my whole life but she rarely, if ever, speaks. She often tells me not to speak, but the opposite seems to have happened. I often think that she is hard-wired for silence but it did not help that my father yelled at her and everyone in our household. I remember thinking the 
roof was going to fall on us from my father's screaming 9 . Only under the rarest circumstances did my mother ever mention her time in Vietnam. My sister told me that as a child my mother was given away by her parents to her aunt's household. The intense anger I feel over this makes me burn red and I have always been distant from my mother's parents. She must have been terrified to go to another family and I imagine she thought she did not deserve better because she was a girl. I would like to go back in time and hold her hand and tell her, "it would be all right."

All I know was that she was a young nurse in Vietnam. I know this only because I saw a picture of her in a white nursing gown. The picture looks quite formal and my mother looked so young and beautiful. She never spoke of her time in Vietnam other than when she was scolding us for not appreciating our life. When I whined about how hard fifth grade multiplication was, she would say, "Don't complain! Someone threw a Molotov cocktail at me during the war." If I mentioned that I had lost a book she would respond, "You have to be more careful with your things because we lost everything in the war." In our family, we were never allowed to complain as we would always be told that life was horrific in Vietnam and we should be grateful. In fact, when I was much older, I was shocked to realize that she could speak Vietnamese fluently. My mother was born in Vietnam but never identified as Vietnamese unlike her decades-younger siblings who went to local school there. So, unlike countless college freshman who write long, "Who Am I", essays, I have never had any identity shock or confusion about who I was ethnically. For as long as I can remember, my mother reinforced our Chinese identity. I once came home from first grade in Catholic school and declared: "I am black"; this was not identity confusion as much as it was the recognition that I had more in common with the two African Americans than I did with the $98 \%$ of the school that was Anglo. My mother did not appreciate my budding intersectionality; she angrily shook me by my shoulders and said," You are not black! You are Chinese." Because I was a relatively obedient child, I followed what she told me from then on and never objected to this. Years later at age 20 my UCLA roommate asked me if I was Chinese-Vietnamese because of my last name and I said, "What are you talking about? No!" Then my professor asked me if I was a "boat person." I again said, "No" mortified that he asked me that question. I did not realize it until this year that my family was part of the 1970s refugee exodus out of SE Asia. In 1976, Vietnam became communist and over 200 thousand Sino-Vietnamese were forced out of Vietnam many repatriated to China.

As an undergraduate, I remember reading about historical horror stories of the Thai pirates who robbed, murdered and molested the fleeing Vietnamese refugees never connecting this to my family at all. I never connected these stories to myself nor my family. Silences can be a form of lying. My family did not go through any of those atrocities as we used our economic power and privilege to leave Vietnam before the war even ended. We left in airplanes before the war ended. As with Leslie Sklair's transnational capitalist class (TCC), we had to use every last one of our economic privilege to leave Vietnam that others could not. ${ }^{10}$ Sklair defines the TCC as groups of people who are not linked to a particular nation state, but instead use commerce to work in several countries to further their capitalistic goals. Many TCC are ethnic middlemen or come from ethnic Middlemen families. We left over five years before the war ended and my father was tasked to starting a new life

9 I do not know why my father always yelled at us. He just did. I know he must have experienced a lot of racism. When the man of color is oppressed by the Anglo man, he turns that anger on his family. He always I don't know why my father constantly told us we were "stupid women" and that "women that did not know anything." This is truism of many people of color families: we have to absorb the humiliated rage of our POC men and still protect them. Since he has a significant accent Midwestern Americans probably assumed, he was not intelligent. Kimberly Crenshaw's "intersectionality" is about how different races, classes, and genders lead to different oppressions and discriminations. Here is where I part from traditional Anglo first-wave, second-wave, and third-wave feminism as my family was influenced by Confucianism. I.will.never.go.against.my.family. Psychologically I find it impossible to go against other Asians, women, or people of color. See Confucian Weekly Bulletin. Confucian Feminism: The (In)Compatibility of Confusianism and Feminist Ethics 儒家思想 与女性主义伦理的 (无) 兼容性. https://confucianweeklybulletin.wordpress.com/tag/Confucian-feminism/ (accessed on 21 April 2019).

10 READ: We bribed our way out. 
in Hong Kong. We cannot compete against Hong Kongers as our Cantonese is ancient and "laughable" out of step-whereas my aunt was discriminated against in Vietnam and often asked when she spoke Vietnamese "Are you from China?" When she was in Hong Kong they judgingly asked "Are you from Vietnam?" I rarely went to family gatherings on my mother's side of the family. When I was 22 , I did and one of my cousins said that according to international law we were considered Vietnamese and I again said, "That's not true!" My father who despises my mother's philandering father would say that my mother's family was just middle class and thus they mixed too much into Vietnamese culture. All of these questions about a possible Vietnamese identity came to a head when I went home and confronted my mother. Is this true? Are we Vietnamese and she said, "No." Then I told her that my aunt said that my grandmother on my mother's side was partly Vietnamese. She told me that I was an infinitesimal amount Vietnamese, and it did not mean anything. She also told me to never tell my father because he would get angry. The larger point here is that my family hides a lot of information and that has even trickled down to the next generations. I have noticed that my generation of cousins are also secretive, flexible, assertive, and vague. They also have varying identities as some identify as fully Vietnamese to partly Chinese-Vietnamese to fully Chinese according to the situation (Trieu 2009). This chameleon adaptation to different environment is something that is passed down from the middle man ethnic families.

\section{1969 Hong Kong, (Then a British Colony)}

Before my parental grandfather died, he sent my father to Hong Kong. Family secrets reveals he was some type of stock broker, but I do not know if this was true. He must have experienced a significant culture shock when he was engulfed by fast paced Hong Kong life. This year, I realized my father did not read mainstream or academic Chinese well since he failed his DMV exam several times in Chinese. He dropped out of French boarding school when he was in the 8th grade and instead told his father he would rather work. My uncle Luk Suk (sixth uncle) once said to me, "I have an accent in every language I speak!" I did not understand what my uncle meant, but I have a better understanding now. Our family is neither here nor there in terms of having a fixed cultural background. Homi Bhabba's migrant theory of "hybridity" — an ethnic in-betweenness is a place my family floated around in many countries (Bhabha 1994). The Cantonese they learned in Vietnam was ancient and out of step with Mainland Chinese norms. When they went to Hong Kong, everyone could hear their ancient Cantonese with Vietnamese inflections. I suspect now that my family could not compete against local Hong Kongers who are so brilliantly urbane.

I once interviewed a Hong Kong Chinese woman who said her greatest prejudice was against the flood of "boat people" refugees who consisted of Sino-Chinese who came from Vietnam to Hong Kong. I realize she was talking about my family. Growing up, my parents never told us we were from Vietnam and when we were old enough to ask, my mother would say, "Don't tell anyone we are from Vietnam. Chinese people look down on Chinese from SE Asia." I even hear this now on my other side of the family. "Don't tell people we are from Vietnam!" I heard my aunt tell her daughter in 2018.

This "middleman minority" family motto is to always improve the lot of the family. We do this by moving, accumulating information, and hypergamy. Susan Ossman would call our family "serial migrants" who go from country to country (Ossman 2013). Ossman's book, Moving Matters is complex and goes beyond the simple binary of home country and the new immigrant country. She writes about how you "accumulate" new knowledge in each country that you settle in, and you then bring that knowledge to third and fourth countries. There is no single story of why migrants move and it is not always simple reason like economics or wars that push people to go to different nation states. It is no accident that four of my cousins and my sister have married Taiwanese and Hong Kong Americans who are considered "higher class" Chinese. These marriages are considered acts of marrying someone of a superior class and culture. 


\subsection{Chinese Hierarchies}

Ali Wong is a Chinese-Vietnamese comedian and writer for the television show, Fresh Off the Boat and the Netflix special Baby Cobra (2016) and Hard Knock Wife (2018). She tells a joke of how her mother is Vietnamese and father is Chinese. She married a Harvard MBA who is half Japanese and half Filipino and they have an unspoken knowledge about themselves. Her joke is that they are both "half fancy Asian" and "half jungle Asian."11 East Asia such as Japan, Korea and China are on top of the Asian hierarchy and also outer Sino-dominate spheres such as Taiwan, Hong Kong and Singapore. The "jungle Asians are primarily from SE Asia" are usually at the bottom of the hierarchy, partly because SE Asians are generally phenotypically darker-skinned. Also, throughout East Asia there are many SE Asian domestic workers who are imported to do domestic work and manual labor (Constable 1997).

My mother always told me to marry someone from Hong Kong or Taiwan but never Mainland China as they might be too chauvinistic or impoverished. It is interesting to contrast this with the cases of new 1990s' millionaire Mainland Chinese who are going all over the world buying houses—a global gentrification which displaces other old-time Chinese populations. The point here is that improvement of the family economics and culture is of utmost priority.

\subsection{Hidden Figure: Aunt Sharon Saves Us All}

My aunt worked as a secretary for the US Army. Her education in Chinese schools and a French boarding school privileged her with some fluency in Vietnamese, Cantonese, Mandarin, Hakka, French and English. Suffice to say, many "middleman minority" families have forked tongues. Tara Yosso's work on community cultural wealth is important here (Yosso 2005). Yosso's work identifies linguistic fluency as a type of wealth that a community can have that is not economic. Her work talks about story telling as a form of resistance capital. My aunt is the untrained oral historian in our family and she tells all the stories in our family. Since I was a child, she would constantly tell us all that we had lost in other nation states and how we are so lucky to have immigrated to the US. She gives dramatic pauses, with often comedic timing, about how we have to work hard and study, but she herself was bad at school. This gave me a lot of solace as a child since I got bad grades in first grade.

Most of the knowledge I have about my family is from stories from her. I have interviewed her, my cousins, and my grandmother many times for other publications (Banh 2019). My aunt Sharon has no children so I and my other cousins are her spiritual children. My father gets angry at her for talking to me. She tells me because of her ability to speak many languages, she was hired by the US Army as a secretary. Seeing how the Vietnam war might end with the Communists winning, she did not want to stay in Vietnam as she knew she would be the target of attacks for her employment. So, she was sponsored by an elderly retired major in Tacoma, Washington, and then sponsored all of us. My father and his sister's family all arrived in New York because that is where their Christian sponsors lived.

\section{1975 Long Island, New York}

My father and mother arrived in New York and immediately obtained custodial and sweatshop jobs respectively. My father cleaned windows and swept floors. My mother pulled electric cords through lamps. Their work life took turns as my mother worked day shifts and my father worked night shifts. Of course, my sister and I would be up during the day and that would anger my father when we made any noise.

My parents scrimped and saved and were able to save enough to move to the Midwest to try their hands at opening a Chinese restaurant. As an adult, I asked my mother why we were raised in an all Anglo and African American Catholic space. I have been told many stories so I am not certain

11 See Ali Wong's hilarious, Netflix special (2016), Baby Cobra which chronicles her travels though sexuality, pregnancy and "trapping" her husband. See Netflix.com. 
which story is true. My mom would interchangeably say, "Baba moved us to the Midwest because it was too competitive in New York and American people don't know Chinese food so it was easy to start a business." Sometimes she would say things like, "Baba never wanted to see any Asians again." Was that war trauma talking? I will never know the truth of why they chose to move to the Midwest, because they became angry whenever I ask them questions.

\section{1980 Bellevue, Illinois}

I grew up in a Chinese Restaurant. It was the lifeblood of our family for a long time. When I was young, my sister and I peeled frozen shrimp and our six- and our eight-year-old little fingers froze while we were doing it. I hate shrimp to this day because I associate it with icy fingers. ${ }^{12}$ We were certainly verbally discriminated against when we lived in Bellevue, but my mother also told me to ignore everything, and so I did. Like many children of immigrants, I often acted as an informal translator for my parents; however, when my parents asked me to translate a customer's racist comments or actions, I knew it would only upset them so I always said something innocuous: "They just wanted more napkins."

Some might say I was an eight-year-old cultural broker for my "middleman minority" family's fourth migration leg (Jezewski and Sotnik 2001). Mary Ann Jewzeski and Paula Sotnik define a "culture broker" as someone who mediates or bridges between different groups and that is what I did before I remember I was even a person. Like many of my students of color, I was the "interpreter" for my parents my entire life (Jezewski and Sotnik 2005). Growing up as a cultural and linguistic translator for my parents made me feel much older than I was.

I have always been protective of my family. This has generalized to feeling I have to protect other Asian people and people of color. This is when my love of anthropology started. It is no accident that I am an Anthropology and Ethnic Studies professor now; the roots were in my upbringing. My father called me "little sister" or mui mui (little sister 妹妹) growing up so I thought I had a high stature in my household never knowing until I was an adult that Chinese people refer to each other not by names but by relational terms: how you are situated in the family. I was the younger sister, so they called me little sister, but in my convoluted child mind I thought it meant I was my father's direct younger sister which meant I had a higher status than my older sister. I enjoyed internal pride over this misunderstanding my entire life.

Our time in Bellevue was bucolic but also stoic. We were never allowed to speak English at home and we could only speak Cantonese to each other. We went to Catholic school. I sensed I was different, but I could never put a finger on it. My only memory of seeing Chinese people (or any Asian people) was when our cousins from Missouri (they also owned a Chinese restaurant) visited us (or vice-versa). Consequently, as a child I thought that every Asian person was a relative. Even today, I have to do a double-take to dissuade my brain from thinking this. It is not lost on me that what one generation tries to hide, the next generation seeks out as I am now an Anthropology and Asian American studies professor.

\section{Food Genealogy in the Chinese American Restaurant}

Owning a Chinese restaurant in Bellevue, Illinois helped my family maintain Chinese language skills, work ethic, and identity (Jung 2011). In the Midwest, there were no Asians where we were located so ethnicity was a moot point. Being in the Chinese restaurant, we never ate the food we served to customers. There were items called St. Paul sandwich which was a large egg patty on top of white bread. There were other things we sold like fried rice, chop suey, and egg foo young that now sound like alien foods to my adult self that has made several trips to Hong Kong and China to eat traditional Chinese cuisine. I am sure Chinese people would be horrified by these concoctions based on local

12 Even if I look or think about shrimp, my finger instantly feels icy and I clench them. I tell people I don't eat shrimp because of global warming, but it is really because it makes me remember my childhood labor. 
midwestern community ingredients. Famous Chef, Martin Yan, argues that restaurants have to survive and you have to sell whatever the community will eat. ${ }^{13}$ Today, one of my cousins still likes to eat these Americanized dishes at successful American Chinese food chains like Panda Express.

There are double menus at Chinese restaurant: One for Americans and another for Chinese people. At our restaurant, our parents cooked us different things from what we sold. We ate white rice with beef and tomato stir-fry. There was the occasional steamed fish dish with ginger soy sauce, and a delectable mapo tofu dish. Stir-fried beef with flat rice noodles and a minced pork patty were mainstays as well as soothing weekend congee that was always served with a fried egg and pork floss. My parents showed us love through food and we always ate well. My parents never bought us books or toys, nor did we ever celebrate Christmas but food was always on the table. I believe I was spoiled by having never had to worry about food. To me, Chinese food is a direct genealogy to my ancestors' culture, history, and life. When I eat Chinese clay pot rice, my eyes get misty because I know all global old timer overseas Chinese people eat it to feel closer to a bygone past. I know traditional Chinese flavor profiles and can tell if the food is a fusion of different cultures.

\section{Three Theories That Apply to My Middleman Family: Serial Migration, Community Cultural Wealth, and Cultural Capital}

Three combined theories can apply to my family transnational migration story: Susan Ossman's serial migration, Tara Yosso's work on community cultural wealth theory and Pierre Bourdieu cultural capital. Susan Ossman's serial migration theory of "accumulating" new knowledge in each country you visit with is something my family experienced. When talking to my uncles and aunts, they mention how the Chinese were discriminated against in Vietnam. Today, I think that discrimination was a psychological "bridge" (or cognitive protective cover) that helped us survive the Midwest American racism. In Vietnam, we were the minorities and now we were again the minorities in a different country. Our family did not miss the country we had left and in fact never spoke of our time there. This makes us very different from ethnic Vietnamese who left their country with regret and sorrow.

Tara Yosso's work on community cultural wealth is also applies in that my middleman family speaks many languages and has many stories of how we survived in quite desperate and hostile spaces. Pierre Bourdieu's "cultural capital" theory also applies in that my family learned new skills in each country that we stayed in. Bourdieu defines cultural capital as "skills, tastes, clothing, mannerism etc." of a certain class that can form a certain identity that others may share (Bourdieu 1984; Richardson 1986). For example, my family has certain business acumen and linguistic traits that have been passed down intergenerationally. Many of my family members are natural "salesmen" for various things. Most of my cousins, who had high school or less educated parents, are very successful doctors, lawyers, and businessmen who went to elite colleges. I have a PhD and am a professor. My best friend Herb once told me that he thought a professor was a type of "middleman." We are all hustler-middleman in different fields, and I mean that in the best sense of the word.

Our "middleman minority" family had definite business skills or Bourdieu's "social capital" that we could transfer over to the new country (Chan 2004). I found it incredible that my cousins owned a grocery store in Vietnam and then reopened another grocery store in Missouri. Our cousins also owned a Chinese restaurant like our family did. The skill set of trade and commerce could be transferred from country to country. We were also very aloof from the American social life as we were from the Vietnamese social systems. For example, my father prides himself on never taking any welfare and we never voted. ${ }^{14}$ Somehow, we survived in the Chinese restaurant, probably making less than $\$ 20,000$ a year.

13 See full interview of Chef Martin Yan (2009) in Banh, Jenny and Haiming Liu, 2019. American Chinese Restaurant: Consumption, Culture and Society, London: Routledge.

14 I vote in every US election and I volunteer to register voters when I can. 


\section{1985 California}

My father was told by my mother's sister that life was better in California, with more opportunity. We left the Midwest and I experienced culture shock when I met my first Asian Americans. A school mate came up to me and spoke Mandarin; I blanched with shock. During this time, I met my maternal grandparents, and they often spoke Vietnamese, which my father did not like. He had passed on his language prejudice to me and I often was also unhappy when Vietnamese was spoken around me. Later, I made Chinese-Vietnamese and Vietnamese friends, including a couple of lifelong girlfriends, when I was an undergraduate at UCLA, so I was able to overcome the discrimination that I was taught. These experiences taught me that prejudice can be passed down in families, but they also can be broken in subsequent generations.

While in California, my father left the restaurant world and became a businessman (again) and did much better financially; eventually, we were able to buy a house and I got to go to school with middle and upper middle-class minorities. I felt quite different from them, as I grew up working and they would tell me stories about how they went on Disney cruises or trips to Taiwan. Their Taiwanese or Hong Kong parents went to college and did not work with their hands as my parents had. My classmates' parents also spoke English, which my parents did not fluently. However, while those language skills might translate into a greater familiarity with mainstream American culture, and maybe even greater opportunities, their parents' English fluency often meant that my Asian and Asian-American friends lost their ethnic tongues. In contrast, growing up in a Chinese restaurant protected me from linguistic erasure and taught me that hard work was a valuable tool when adapting to the challenges of school. This might seem antithetical to the Model Minority Myth, but I was also taught that education was not the most important thing. Instead, making a living and supporting the family, with your hands if need be, was the most crucial. I tried to endure and never gave up. I am a hard worker like my ancestors and descendants. I was a passable student with fits of writing here and there. But somehow, I knew I was from Hong Kong, even if it was in a simulacra way; I made it a point to do my PhD fieldwork in Hong Kong.

\section{2012 Fieldwork: Back to Hong Kong}

I experienced culture shock when I went to Hong Kong for my anthropological fieldwork. I wonder now was it something similar to what my grandfather and father/mother felt years ago? In 2012, while carrying out my anthropological fieldwork, I met Sino-Vietnamese custodial workers. When they heard my Cantonese, one of the women asked me if I was a "Chinese Vietnamese overseas bridge" (Zhōngguó yuènán qiáoliáng 中国越南桥梁) and I, to my own astonishment, said, "Yes." As a graduate student with a young family, I finally arrived in Hong Kong-although my parents had told me not to go. They said Hong Kong was dangerous and the people untrustworthy, but I soon discovered the opposite. During my fieldwork, I was able to travel to Vietnam to look around, but I felt nothing. Only ghosts are there and I did not dare to ask where my grandparent's old house was. In Hong Kong, I walked with my eight-year-old daughter and six-year-old son and told them that our family had lived here for a time and that they must come back if things go south in the United States. Because of significant effort on my part (with a great deal of assistance from my parents), my kids can speak both Cantonese and Mandarin and write Chinese characters, something I think is a minor miracle given the increasing dominance of English in my own life. Just like my grandfather preached the importance of language retention to my father, I pushed language fluency to my children. If asked, I often say that these language skills are important for practical reasons (being able to compete in a global labor market, for example) but between you and me, given my family's history, I see my kids' language skills as a survival tool should they ever need to escape to a Chinese-speaking part of the world. I constantly remind myself and my children of a quote from Aiwha Ong's Flexible Citizenship where a Chinese diasporic man says something along the lines of: "I can live anywhere in the world as long as it is close to an airport" (Ong 1999). 


\section{2016 Time Is a Circle: San Gabriel Valley, CA}

My parents, sister, cousins, and for a time my own family, lived in California's San Gabriel Valley, the famous Chinese culinary capital colloquially known (from its telephone area code) as the "626." Unlike me, my kids have grown up around diverse and authentic Chinese food created and consumed by Chinese ethnics just like us-overseas bridges or Hua Kiu (Hua Kiu means Chinese "overseas bridges") who live outside of China In communities like Alhambra, San Gabriel, Monterey Park, and Rosemead, you will find Chinese Vietnamese, Chinese Cambodians, Chinese Indians, Chinese Indonesians, Chinese Filipinos, Chinese Thai, Chinese Malaysians, Chinese Burmese, etc. (Chan 2004)..$^{15}$ They all have family stories very similar to mine because their families also had businesses in SE Asia and they had to flee when the local population turned on them. They are also successful runners, but they all bear scars from their time in SE Asia. Like my family, many are secretive, distrustful, and fatalistic. When I go into donut shops invariably owned by Chinese-Cambodians, I remember that around half of the Chinese Cambodian population was killed in the Cambodian genocide and forced labor camps. My Chinese Filipino friends relate stories of kidnapping attempts on them. My Chinese Indonesian friends speak of the mass rapes that the Chinese-Indonesians were subjected to and how even the police officers stabbed Chinese Indonesians in the stomach. My observation is that many of these SE-Sino groups also harbor similar ambivalence to negative opinions of the local community they fled from.

Today, I teach at a university that is predominately SE Asian American with many Hmong, Mien, Laotian, Vietnamese, and Cambodian diasporic students (Dufoix 2008). ${ }^{16}$ These students are "double minorities" like myself. I define double minorities as minorities within minorities that are often non-legible in standard categories. They are second generation SE Asian Americans, many of whom are part Chinese who are trying to make their way. They have family secrets too, but they all survived, and I am sure their genetic makeup has been transformed from those experiences. Ready to pass to the next runner generation.

I try to teach my children that they have to flee if things get bad and they can start again if they need to. If they "work hard" and put their heads down, they can start again from nothing, anywhere in the world and be successful. I acknowledge the "putting your head down" plays into the Model Minority Myth of Asians being "over-competent but forever foreigners" so it is my struggle to go against this sentiment that I was taught. I teach my Ethnic Studies students that Asian Americans are used as a sword to wound African Americans and other people of color. The Asian American "Model Minority" is a myth that serves to divide and conquer people of color in the United States. ${ }^{17}$ Anagnostou (2003) writes on "Model Americans" in Diaspora journal: on the "price" of certain kinds of identification in the assimilation context, which have psychological costs as well as particular advantages.

Time is a circle. It is in my blood to go from country to country and start again. I have confidence that I can do it and I have to keep this spirit alive in my descendants that I received from my ancestors. Since time is a circle, we are due to migrate to a different country soon.

Funding: This research was funded by California State University, Fresno College of Social Science faculty grant.

Acknowledgments: I would like to thank the two anonymous reviewers and also editor Philip Q. Yang for his sage direction. I would like to thank Sean Slusser, Eugene Anderson, Haiming Liu, Genevieve Beenen, and Ray Pun for offering sage advice. I would like to thank Melissa King and Aurora Chang for giving me much needed theoretical leads.

Conflicts of Interest: The author declares no conflict of interest.

15 This is not including the old-time Chinese populations from Hong Kong and China and now newly arrived Mainland Chinese. There has been a lot of disputes between the old time Chinese and the new Mainlanders who are demolishing houses and building huge mansions obscuring the view of others. They also drive up the home prices for many people in the 626 .

16 My university also had Oaxacan Mexicans who are an indigenous group in Mexico. I especially identify with them as they are also double minorities.

17 Asian Americans did not invent the Model Minority term. See Success Story, Japanese-American Style By William Petersen. New York Times. Jan 9, 1966; ProQuest Historical Newspapers The New York Times (1851-2006) p. 180. 


\section{References}

Anagnostou, Yiorgos. 2003. Model Americans, Quintessential Greeks: Ethnic Success and Assimilation in Diaspora. Diaspora: A Journal of Transnational Studies 12: 279-327. Available online: https://muse.jhu.edu/ (accessed on 3 June 2019).

Anderson, Eugene N., and Barbara Anderson. 2012. Warning Signs of Genocide: An Anthropological Perspective. Lanham: Lexington.

Appadurai, Arjun. 1996. Modernity at Large: Cultural Dimensions of Globalization. Minneapolis: University of Minnesota Press.

Banh, Jenny. 2019. Chinese Restaurant Kids Speak About Labor, Lifeways and Legacies. In American Chinese Restaurant: Society, Culture, and Consumption. Edited by Jenny Banh and Haiming Liu. London: Routledge.

Bechdel, Alison. 2013. Are You My Mother? A Comic Drama. Indianapolis: Mariner Books.

Bhabha, Hommi. 1994. The Location of Culture. London and New York: Routledge.

Bonacich, Edna. 1973. A Theory of Middleman Minorities. American Sociological Review 38: 583-94. [CrossRef]

Bourdieu, Pierre. 1984. Distinction: A Social Critique of the Judgement of Taste. Cambridge: Harvard University Press. Bui, Thi. 2017. The Best We Could Do. New York: Harry N. Abrams.

Chan, Sucheng. 2004. Survivors: Cambodian Refugees in the United States. Urbana: University of Illinois Press.

Chan, Sucheng. 2006. The Vietnamese 1.5 Generation: Stories of War, Revolution, Flight, and New Beginnings. Philadelphia: Temple University Press.

Chee-Beng, Tan. 2013. Handbook of the Chinese Diaspora. New York: Routledge.

Constable, Nicole. 1997. Made to Order: Stories of Migrant Workers. Ithaca: Cornell University Press.

De Mente, Boye Lafayette. 2009. The Chinese Mind: Understanding Traditional Chinese Beliefs and Their Influence on Contemporary Culture. Clarendon: Tuttle Publishing.

Desai, D. R. Sar. 2009. Southeast Asia: Past and Present. Boulder: Westview Press.

Dufoix, Stephane. 2008. Diaspora. Oakland: University of California Press, pp. 46-50, 72-74.

Gellately, Robert, and Ben Kiernan. 2003. The Specter of Genocide: Mass Muder in Historical Perspective. Cambridge: Cambridge University Press, pp. 313-314.

Hancock, Ange-Marie. 2013. Solidarity for Millennials: A Guide to Ending Oppression Olympics. New York: Palgrave Macmillan.

Jezewski, Mary Ann, and Paula Sotnik. 2001. Cultural Brokering: Providing Culturally Competent Rehabilitation Services to Foreign-Born Persons. Buffalo: Center for International Rehabilitation Research Information \& Exchange.

Jezewski, Mary Ann, and Paula Sotnik. 2005. Culture and Disability Services (with a Focus on Culture and Foreign-Born Characteristics). In Culture and Disability: Providing Culturally Competent Services. Edited by John H. Stone. Thousand Oaks: Sage, pp. 15-31.

Jung, John. 2011. Sweet and Sour: Life in Chinese Family Restaurants. Cypress: Yin and Yang Press.

Kingston, Maxine Hong. 1975. The Women Warrior. New York: Alfred A. Knopf, p. 1.

Lipner, Julius. 2012. Hindus: Their Religious Beliefs and Practices. New York: Routledge.

Marx, Karl, and Friedrich Engels. 2019. The Communist Manifesto. New York: Penguin. First published 1848.

Ong, Aiwha. 1999. Flexible Citizenship: The Cultural Logics of Transnationality. Durham: Duke University Press.

Osman, Urfika, and Ulma Hayanto. 2010. Still No Answers, or Peace, for Many Rape Victims. Jakata Globe. May 14. Available online: https://web.archive.org/web/20100904160043/http://www.thejakartaglobe.com/ national/still-no-answers-or-peace-for-many-rape-victims/374845 (accessed on 1 June 2019).

Ossman, Susan. 2013. Moving Matters: Paths of Serial Migration. Palo Alto: Stanford University Press.

Pan, Lynn. 1998. The Encyclopedia of Chinese Overseas. Cambridge: Harvard University Press, pp. 228-33.

Richardson, John. 1986. The Forms of Capital. In Handbook of Theory and Research for the Sociology of Education. New York: Greenwood, pp. 241-58.

Said, Edward. 1979. Orientalism. New York: Vintage.

Shepherd, John Robert. 2019. Footbinding as Fashion: Ethnicity, Labor, and Status in Traditional China. Seattle: University of Washington Press.

Takaki, Ronald. 1989. Strangers from a Different Shore. New York: Back Bay Books.

Trieu, Monica. 2009. Identity Construction among Chinese-Vietnamese Americans: Being, Becoming, and Belonging. El Paso: LFB Scholarly Publishing. 
Vickery, Michael. 1984. Cambodia: 1975-1982. Boston: South End Press.

Wang, Gungwu. 2002. The Chinese Overseas: From Earthbound China to the Quest for Autonomy. Cambridge: Harvard University Press.

Yan, Martin. 2002. Martin Yan's Chinatown Cooking: 200 Traditional Recipes from 11 Chinatowns around the World. New York: William Morrow Cookbooks.

Yosso, Tara J. 2005. Whose Culture Has Capital? A Critical Race Theory Discussion of Community Cultural Wealth. Race Ethnicity and Education 8: 69-91. [CrossRef]

(C) 2019 by the author. Licensee MDPI, Basel, Switzerland. This article is an open access article distributed under the terms and conditions of the Creative Commons Attribution (CC BY) license (http://creativecommons.org/licenses/by/4.0/). 


\title{
Facebook and WhatsApp as Elements in Transnational Care Chains for the Trinidadian Diaspora
}

\author{
Dwaine Plaza * and Lauren Plaza * \\ Sociology Department, Oregon State University, Corvallis, OR 97331, USA \\ * Correspondence: dplaza@orst.edu (D.P.); laurensplaza@gmail.com (L.P.)
}

Received: 4 February 2019; Accepted: 27 March 2019; Published: 2 April 2019

check for updates

\begin{abstract}
Despite being separated by great geographical distances, the Trinidadian Diaspora community has managed to stay in regular communication with those back "home" using the latest available technologies. Trinidadian migrants living abroad have established multi-directional care chains with family, kin, and friends that have endured for decades. This social connection has evolved from letter writing, telegrams, telephones, emails, and most recently, internet-based social media which includes: Facebook, WhatsApp, Skype, Facetime, Snapchat, Twitter, and Google Hangout. This paper examines how social media, focusing on Facebook and WhatsApp, are tools being used by the Trinidadian Diaspora to provide transnational care-giving to family and friends kin left behind in the "home" country and beyond. The analysis is based on the results of two online Qualtrics surveys, one implemented in $2012(n=150)$ and another in $2015(n=100)$ of Trinidadian Diaspora participants and in-depth interviews with $(n=10)$ Canadian-Trinidadians. This paper explores how social media have become a virtual transnational bridge that connects the Trinidadian Diaspora across long distances and provides family members with a feeling of psychological well-being.
\end{abstract}

Keywords: transnational; care chains; diaspora; Trinidad; family; immigrants; social media; Facebook; WhatsApp

\section{Introduction}

"A few years ago, I discovered Facebook, it allowed me to connect with my family in Trinidad, Miami, and New York. More recently, I discovered FaceTime and WhatsApp ... these two applications on my smartphone allow me to hook up to everyone for free. Trini's like free you know .... . No really what it means is that I am talking to everyone all the time and I keep track of all the happenings my nieces and nephews are getting up to. They use the technology and keep me up to date on Trinidad and their parents ... my sister and brother. It use to cost me $\$ 2.00$ a minute when I first moved to Toronto to call family, so you know that only happened on special days like Christmas day, New Years, birthdays, and the like. Using the new technology I can now maco everyone's business as it happens."

(Linda, a fifty-four year old, Indo-Trinidadian)

Since the 1960s, international migration has become less traumatic in terms of the forever severing of family ties. Less expensive real-time communication and airline transportation links have meant that families living in the Diaspora have not had to completely sever the emotional associations between family members (Baldassar et al. 2006; Bryceson and Vuorela 2002). At the heart of today's transnational family obligations and emotional ties has been the ability to stay in immediate communication with family members who are sprinkled throughout the international Diaspora and those still in the home country. The Internet and social media have become the latest communication revolution that facilitates 
the free flow of news and updates that are taking place. Family members, kin and fictive kin can now use this relatively free technology to know about what is happening to each other. Having this communication flow results in individuals across vast reaches of the Diaspora feeling a sense of mattering and belonging.

Trinidadian people have a long history of surviving economic adversity by moving north to the United Kingdom, the United States, and Canada where jobs and opportunities for mobility were perceived as more abundant. The contemporary Trinidadian Diaspora is a product of a "culture of migration" which developed as a survival strategy in the context of a long secular decline in sugar production and plantation agriculture starting in the early 1800s (Marshall 1982). Despite migrating away from their place of birth in pursuit of better opportunities, Trinidadian people always brought with them aspects of their Creole cultural socialization and a desire to return one day (Lowenthal 1972). Immediate family and extended kin from both the home country and from the Diaspora play significant roles in the migration strategy of Trinidadian men and women. They often assist in the financing of initial migration, caring for the children of absent parents, and helping to obtain employment in settlement communities (Basch 2001). Consequently, most sojourners carried with them a cultural obligation to care for and worry about those family members left behind. This obligation could be satisfied by staying in touch, sending back regular remittances or by creating avenues for family, kin, and fictive kin to also migrate through sponsorship.

Since the 1960s, a Trinidadian international "Diaspora" emerged in some major cities in the Eastern United States. Approximately 181,290 Trinidadians reside in New York, Boston, and Miami. Another, 21,285 reside in the United Kingdom (London, Manchester, Birmingham) and approximately 78,965 live in Canada (Toronto, Montreal and Winnipeg) (Simmons and Plaza 2006). The formation of large Trinidadian-origin migrant communities in these cities and the resources that such immigrant communities provided to new migrants strengthened and transformed the culture of migration. Trinidadian migrants living in the Diaspora began to see themselves as both "here" and "there" in Caribbean social spaces although they were living abroad. "Home" began to be viewed not just as the place where one was born or just where one lived, but more generally anywhere friends, relatives, and members of the cultural community were to be found (Simmons and Plaza 2006). In effect, this began as a Trinidadian culture of migration ${ }^{1}$ that expanded over time to become a Caribbean transnational cultural Diaspora community. Thus, the culture of migration was retained as one key element in this geographically spread out transnational community. Despite being separated by great geographical distances, the transnational Trinidadian community has managed to stay in regular communication as a survival strategy and as a means to maintain psychological and social well-being.

A moral obligation dimension is crucial to understanding the caring about and caring for kin relationships within transnational Caribbean family and kinship networks in general. Finch and Mason (1990) advocate the concept of "kinship morality" to suggest that a set of moral discourses inform the behavior of individuals toward their kin in the Caribbean. Similarly, Williams (2004) suggests that people negotiate their transnational familial relationships within these moral guidelines, and act as moral agents involved in negotiating "the proper thing to do" in and through their commitments to others. These caring commitments may cross the boundaries of blood, marriage, residence, culture, and country (Reynolds 2006). Caring about family encompasses contact and emotional support and refers to emotional functions connected with sociability, advice, comfort, and self-validation. Activities which express caring about family include communication by social media, telephone, letters, email, return visits, participation in family decision making and sending of remittances, whereas caring for family refers to concrete, hands-on care-giving. An example of the

1 According to Foner (1997), “Migration has been a constant motif of the Caribbean story." Migration is the single most common response to blocked mobility associated with living in the Caribbean region. People grow up thinking that economic success is more viable to those who have an opportunity to travel abroad for work and better opportunities. 
latter is sending for elderly relatives to live in the metropolitan countries so that they can be eligible to receive good healthcare (Finch and Mason 1990).

Caring about family members and kin seems to assume a crucial relevance in the context of migration and geographically dispersed families. The very existence of transnational families rests on the vitality and durability of kin ties in spite of great distances and prolonged separations (Reynolds 2004). Reynolds (2005) notes that cultural remittance represents emotional attachments and the way in which migrants abroad utilize their family links to maintain cultural connections to their place of origin (Levitt 2001). Other forms of cultural remittance include owning property and building a future retirement residence back "home", the celebration of traditional cultural rituals and/or recognition of national events from back "home", and keeping abreast of news back "home" through the Internet and newspapers (Horst and Miller 2006). Cultural remittance reinforces ethnic identity and is viewed as a sign of continued commitment to the kin left behind, as well as a commitment to keeping kin together.

As the Internet emerged to give immigrants a sense of community (Grudz and Takheteyev 2011; Karim 2003; Mitra 1997), the notion of fixed communities has been questioned (Cohen 1997; Klak 1998; Okafor and Honey 1998). Ignacio (2005), in her study of the Filipino Diaspora, explored how this group has used the Internet and computer-mediated communication particularly, newsgroup debates, list servers, and website postings, as platforms to build relationships and communities and to create and reinforce their national ethnic and racial identity. Asal (2012), in a study of Lebanese Diasporas concluded that these new technologies have enabled immigrants to create and sustain links with their homeland, host country, and each other, share information, and organize transnational networks (Brettell 2007; Enteen 2006; Graziano 2012; Nurse 2000; Smith and Bakker 2008; Tekwani 2003).

As a networking platform, Facebook has been the most used social media communication technology that continues to unite the Caribbean Diaspora community. ${ }^{2}$ WhatsApp on the other hand, is a smartphone application that enables people to share information directly via their phones. Since its introduction in 2009, its growth has steadily increased, and as of April 2016, it numbers over 1.5 billion users and WhatsApp sees 60 billion messages sent each day. ${ }^{3}$ While many alternatives to WhatsApp are currently available, (e.g., Kik, Telegram, Line Messenger, BBM, WeChat), WhatsApp is currently the most popular messaging application used by Trinidadians in the Diaspora. WhatsApp has the largest name recognition, by far the largest user base, and the strongest corporate backing since it was acquired by Facebook in 2014.

The quote at the beginning of this paper shows that Trinidadians like Linda use the Facebook platform and other social media applications like WhatsApp and FaceTime as tools to maintain friendships and acquaintances, keep in touch with family, provide long distance caring and nurturing, and to reminisce about the nostalgic past. These are all important tools for the Trinidadian Diaspora because the technology helps to fulfil an individual's feeling of obligation to remain in touch with family and kin. In this study, we will focus on the Trinidadian immigrant cohort living in Canada in order to determine just how importantly social media have been used in terms of helping to maintain, and solidify linkages of transnational caring chains (Olwig-Fog 2012). Social media provides a number of latent transnational functions for Caribbean people living in the international Diaspora. These functions include, acting as a tool to solidify linkages of obligation and transnational caring; reducing the degree of alienation; and cultural mourning experienced after migration (Ainslie 1998), thus rekindling a sense of mattering and belonging, thereby improving an individual's self-esteem in the

2 In 2000, there was an estimated 414,794,957 internet users worldwide, which represented $6.8 \%$ of the world's population. By 2016, the number of internet users had jumped to an estimated 3,424,971,237 or approximately $46 \%$ of the world's population. The number of internet users in the Caribbean is approximately $42,401,541$. In Trinidad, fifty-seven percent of the 1.2 million people report having Facebook users accounts (www.internetworldstats.com 2017).

3 The average WhatsApp user sends over 1000 messages per month with over 2000 messages being received. Average users upload 40 photos, send 13 voice messages and 7 video messages (Statista). Facebook paid \$19 billion dollars in 2014 to acquire WhatsApp. 
Diaspora (Schlossberg 1989). This is particularly important for Caribbean-origin individuals and families who are now separated by physical space, time zones, and other barriers like immigration policy which may restrict the Caribbean-origin immigrant's desire to open the door and allow kin and fictive kin an opportunity to reunite in a single metropolitan space.

\section{Theoretical Background}

The term transnational was originally conceived as a reaction to the vague nature of the term Diaspora as well as, a means of accounting for the ways in which new technology and transport make possible multiple associations (Portes et al. 1999; Vertovec 1999). The original distinction between transnational and Diaspora has been blurred together to such an extent that the two terms have become almost interchangeable when describing Caribbean migrants living outside their home countries like Trinidad, Jamaica or Guyana. Transnational existence is the process by which immigrants forge and sustain multi-stranded social relations between their societies of origin and settlement (Basch et al. 1994). Wise and Velayutham (2006) use the term "transnational affect" to describe the emotional aspects of transnationalism that involve mourning for "home" and a feeling of obligation to help those left behind that many members of the Diaspora feel. Members of transnational families live in geographically dispersed locations (Herrera 2001). Despite the separation caused by national borders and distances, transnational families often look after one another, share resources, and maintain their social relations (Bryceson and Vuorela 2002). Kofman and Raghuram (2006), refer to care as "the work of looking after the physical, psychological, emotional and developmental needs of one or more people", thus arguing that this work "embraces a range of human experiences and relationships of obligation, trust, loyalty and commitment concerned with the well-being of others". The members of transnational families also provide emotional care and guidance despite the distance of separation (Hondagneu-Sotelo and Avila 1997). The effect of transnational family life on children is examined by Mazzucato and Schans (2011). Glick (2010) provides a review of the literature on immigrant families, while Carling et al. (2011) explore the difficulties of transnational parenthood.

Di Leonardo (1987) calls the transnational activities that take place between kin members a symbiotic relationship that includes the development, maintenance, and ritual celebration of cross-household kinship ties, as "kin work". The concept of "global care chains" has also been used by researchers to explore the nature and dynamics of transnational care. The concept used by Hochschild (2000), and expanded by Parreñas (2005a, 2005b), refers to "personal links between people across the globe based on the paid or unpaid work of caring." Sorensen and Vammen (2014) advance the work on transnational care chains by examining the place of motherhood, fatherhood, and childhood in global spaces. Dossa et al. (2017) note that these transnational care chains can become overbearing particularly when migrants feel compelled to take on extra employment in order to fulfill a perceived cultural obligation for sending a steady stream of remittances to individuals who are in greater need.

Most of the research which has been done on remittance practices focuses mainly on the magnitude and impact of remittances on households and communities in other developing countries (Rubenstein 1983; Massey and Parrado 1994). Policy initiatives to enhance the development impact of remittance flows have also been the subject of a number of policy reviews by international agencies (Orozco 2002, 2004). However, much less is known about the volume, frequency, or cultural practices related to the sending of soft goods by Diaspora migrants to their family, kin and fictive kin who live in the Caribbean. Recent research on remittances has taken a positive view of the overall volume of remittances celebrating migrants' role as agents of development (De Haas 2010; Fajnzylber and López 2008; Levitt and Nieves 2011) in connection with the formation of transnational communities. Social remittances connections occur through direct contact between a sending and receiving culture, or through the exchange of letters, videos, photos, emails, blog posts and phone calls. The transnational network enables cultural reproduction of social remittances; the ideas and practices migrants bring with them actively shape who and what they encounter in the countries where 
they move, which then shapes what they send back. This pressure can have detrimental effects on an individual's physical and mental health particularly if they are dealing with multiple variables so that they may be able to save and sacrifice so that family back "home" or scattered throughout the Diaspora may be cared for (Parreñas 2005a).

Initially introduced by Becker (1960), the term "negotiated family commitments" refers to the compromise and re-negotiation of family responsibilities over time. This family responsibility is often associated with the physical co-presence and touch as well as emotional, moral, practical, and financial types of care. One person in the chain helps another person out in crisis and the other person then wants to return the kindness to others in the chain once they are back on their feet (Finch and Mason 1993, p. 167). The expression "obligation" refers to cultural expectations of caring assigned to someone's social role as defined by age, gender, and family position

Finch and Mason (1993) used Becker's idea to create the term "transnational care-giving". Later, Baldassar et al. (2006) expounded on the earlier theories to establish the paradigm of transnational family care giving. This paradigm draws heavily on a view by Bryceson and Vuorela $(2002$, p. 3) who defined trans-national families as "families that live some or most of the time separated from each other, yet hold together and create something that can be seen as a feeling of collective welfare and unity, namely "family hood", even across international borders." According to this description, family care is a main feature of transnational families (Kilkey and Merla 2014). Moreover, transnational care giving is understood as a process that embraces family members of multiple generations, including the able-bodied as well as those in need of care. A key to the concept of transnational care giving is the understanding of care as a multi-dimensional, multigenerational, and multidirectional phenomenon.

Care giving has received significant attention in studies on migration (Ackers and Stalford 2004). A number of studies examine the transnational activities of women in relation to family and kin (Alicea 1997; Foner 1997; Zontini 2004) but only very few researchers have focused on caring for elderly relatives in transnational settings (Ackers and Stalford 2004; Baldassar et al. 2006; Baldock 2000; Lan 2002). Caribbean scholars like Barrow (2010) and Jokhan (2008) note that migrants from the English speaking Caribbean are part of multi-directional care giving chains that ensure children left behind are taken care of by kin and fictive kin. Members of transnational Caribbean family chains often feel a strong obligation to keep in touch with, care for and look after members of their family despite the physical distance or the time that has passed since migration.

Various studies observe that Caribbean migrants do "kin work". They do not forget their home communities or lose contact with families, community organizations, and political movements in their countries of origin as they become part of a new society (Ho 1993; Olwig-Fog 2002). In the Caribbean, a majority of individuals belong to extended family networks that provide a sense of identity and belonging (Ellison 1985). This cultural pattern of two way kin care acts as an insurance policy whereby the migrant knows that if she/he becomes in need of personal care due to old age, sickness or some other affliction, they can rely on their kin and fictive kin networks to reciprocate care.

Caribbean family researchers (Barrow 2010; Jokhan 2008; and Reynolds 2005) have differentiated between two forms of family obligations that provide a useful starting point for understanding Caribbean transnational family care chains. The two forms are caring about family and caring for family (Ackers and Stalford 2004). Caring about family encompasses contact and emotional support and refers to emotional functions connected with sociability, advice, comfort and self-validation. Examples of caring about family activities include communication by social media, telephone, letters, electronic mail, return visits, participation in family decision-making and sending of remittances. Caring for family refers to "hands-on" care-giving on a personal level. Examples of this include sending for elderly family relations (e.g., mothers, aunts and fathers) to live in the metropolitan countries so that they may be eligible to receive healthcare support not available in the home country (Finch and Mason 1993).

Multi-directional caring for practices, obligations and responsibilities continues to operate within the family networks of Trinidadian Diaspora families. Their accounts of daily activities and family 
relationships provide a wealth and range of examples of transnational care provision between family members. The most common is care between parents and children, siblings, grandparents and grandchildren, affluent and less wealthy family members (Olwig-Fog 2012).

A moral obligation dimension is crucial to understanding the caring-about and caring-for-kin relationships within transnational Caribbean family and kinship networks in general. Another pressing factor that helps to solidify the relations between family in the Caribbean and Diaspora is the decline in economic and material conditions in the Caribbean due to government policies like structural adjustment (Barrow 1996). Finch and Mason (1993) advocate the concept of "kinship morality" to suggest that a set of moral discourses inform the behavior of individuals towards their kin in the Caribbean Diaspora. Similarly, Wilder (2006) suggests that people negotiate their transnational familial relationships within these moral guidelines, and they act as moral agents involved in negotiating "the proper thing to do" in and through their commitments to others. These caring commitments may "cross" the boundaries of blood, marriage, residence, culture and country. This can manifest itself in terms of caring for fictive kin (Reynolds 2006).

Caring about family members and kin seemed to assume a crucial relevance in the context of Caribbean migration and geographically dispersed families. The very existence of transnational Caribbean families does, in fact, rest on kin ties being kept alive and maintained, in spite of great distances and prolonged separations (Reynolds 2004). Reynolds (2005) adopted the term cultural remittance to advance the theory of transnational caring about relationships. She noted that Caribbean cultural remittance represents people's emotional attachments and the way in which migrants abroad utilize their family links to maintain cultural connections to their place of origin (Burman 2002; Levitt 2001). Other forms of cultural remittance included owning and building property "back home", the celebration of cultural rituals and national events in the new country of residence, and keeping abreast of national news "back home" through the Internet and newspapers (Horst and Miller 2006). Cultural remittance reinforced ethnic identity and was viewed as a sign of continued commitment to the kin left behind and a commitment to keeping kin together.

The first decade of the twenty-first century witnessed tremendous advances in internet technology. Vertovec (2004) argues that nothing has facilitated processes of multi-directional caring for practices than the boom in cheap telecommunication options, especially among non-elite social groups. Advancements in communication technology have facilitated higher rates of connectivity between migrants, kin and, fictive kin still living in their homelands. More recently, high speed internet connections have begun to be incorporated into the repertoire of transnational communication options for immigrants living in metropolitan countries (Senyurekli and Detzner 2009). This has provided transnational migrants with an additional, extremely versatile, tool of communication. Panagakos and Horst (2006) suggest that newer modes of communication technology, such as teleconferencing (e.g., Skype, Facetime, or Google Hangouts), provide a visual and real time medium that has the potential to amplify emotional connections and may in some ways decrease the need to physically visit "home." Many migrant groups report that the increased ability to communicate across borders has been beneficial for maintaining social ties (Horst 2006; Parreñas 2005b; Senyurekli and Detzner 2009). Having real time information via social media about the material, economic, and general conditions in the Caribbean, family members in the Diaspora cannot claim they were oblivious and, therefore, not responsible for helping. Social media have elevated the level of responsibility a migrant might experience from his/her kin and fictive kin left back in their place of origin.

\section{Methods and Procedures}

This paper is based on both quantitative and qualitative data. The data sources include the results of two online Qualtrics surveys, one implemented in $2012(n=150)$ and another in $2015(n=100)$ of Trinidadian Diaspora participants and interviews with $(n=10)$ Trinidadian-origin men and women over the age of forty who live in Toronto Canada. We found that Facebook, WhatsApp, Skype, Facetime, Snapchat, Twitter, and Google Hangouts were used to facilitate long distance care giving because these 
free applications allowed Trinidadian family members living in the Diaspora to communicate verbally and visually twenty-four hours a day. This was unlike earlier times when the cost of a phone call from North America or Europe to Trinidad was almost two dollars per minute. These high costs meant that communication between the two locations was often restricted to emergencies or special family event gatherings like Christmas, birthdays, and special events like Mother's day. Prior to the Internet, much of the communication was done by regular mail using the postal services. The respondents to the surveys came from various Trinidadian-origin ethnic groups which included: African, Indian, Chinese, European and other mixed ethnicities. It was important to have representatives from these ethnic groups because families who originated from Trinidad are heterogeneous.

A purposive snowball sample was used in which the interview participants were selected through their acquaintance with the researchers (whose origins are Trinidadian), through references provided by friends, colleagues, relatives and the participants. All of the interviews were audio taped and took between one and two hours to complete. The surveys were distributed through Qualtrics, an online internet survey platform. Facebook respondents were solicited through friendship networks using a snowball sampling method. We used family, friends and acquaintances of the researchers' social media networks to inform potential participants about the survey online. Once participants completed the survey they were asked to forward the survey URL link to at least five of their Trinidadian friends. The survey results are not based on a random selection of the population. There is an inherent bias in using the researchers' Facebook networks because we both tend to know Trinidadians who are middle to upper middle class, college-educated men and women. We were not successful in attracting working class individuals to complete the survey. The sample size being small and focused on Trinidadians means that the results from both surveys need to be interpreted with caution and may not be generalizable to other Caribbean Diasporas (Jamaicans, Barbadians, Guyanese etc.). Despite these limitations this study represents the first time that any Caribbean researchers have been able to look at the use of social media as a tool for long distance caring. Future studies will need to be implemented that focus on improving the sampling methodology to capture different classes of Trinidadians and expand to include Jamaicans, Barbadians and Guyanese immigrants living in the Diaspora.

The qualitative interviews were transcribed and analyzed using the strategy of the "constant comparative method of analysis," a strategy of data analysis that calls for the continual "making comparisons" and "asking questions" of the data (Strauss and Corbin 1990). The data were coded and sorted according to emerging themes. These themes were then compared to each other to determine which were showing consistency. According to Patton (2002), inductive analysis allows for "categories or dimensions to emerge from open-ended observations as the inquirer comes to understand patterns that exist in the phenomenon being investigated". Essentially, as Patton (2002) notes, this type of analysis involves identifying categories, patterns, and themes in one's data through one's interaction with the data. After this analysis, similarities and differences in each code were documented based on our personal understanding, professional knowledge of transnational migration, and the literature on family care-chains.

The use of multiple research methods for studying transnational family care chains has allowed us to explore the way in which social media applications are being used as tools to facilitate long distance care. We were also able to examine how social media provide Trinidadians living abroad who are experiencing cultural mourning (or alienation) an opportunity to rekindle a sense of mattering and belonging in the international Diaspora. This case study approach for examining social media as it applies to Trinidadians is exploratory and cannot be generalized due to the small sample size. What is important about this research is that it begins to shed light on the way the Trinidadian Diaspora of migrants are using social media to assist in the maintenance of transnational care-chains.

\section{Characteristics of the Trinidad Facebook and WhatsApp Sample}

Table 1 in the appendices provides a summary of the ten Trinidadian-origin men and women who were interviewed for this study. The oldest person was sixty-eight while the youngest was forty-one. 
The youngest person interviewed was included in this researcher's because he spent a great deal of time reflecting on the loss he felt after his uncle returned to Trinidad to retire. The sample consisted mainly of women who were generally much easier to recruit. The women in this sample were in general high users of social media in order to stay in touch with relatives in the Diaspora. The men in the sample were mixed in terms of their reported use of social media to stay in touch with family. The men reported staying in contact using WhatsApp and texting while women used all aspects of social media to stay in touch with family and kin in Trinidad. The sample was fairly diverse in terms of their length of time living in Canada. Most had migrated twenty or more years ago. This sampling bias occurred because of the researchers network of potential interviewees from Trinidad were all first and second generation men and women currently living in Toronto. These subjects were willing to provide their time to be interviewed. One person reported that they migrated to Canada forty-four years ago. In terms of occupation, there was a mixture of job titles like social worker, barrister, architect, teacher and nurse. Most of the respondents reported still having many family members living in Trinidad. This ranged from twenty-five to one hundred relatives. All of the respondents reported having many family members living in Canada. This ranged from twenty-two to sixty-six relatives. Because of the large number of families both in Trinidad and Canada, it is of little surprise that these respondents in general reported high levels of social media usage in their quest to stay in touch and provide family and friends long distance emotional care. 
Genealogy 2019, 3, 15

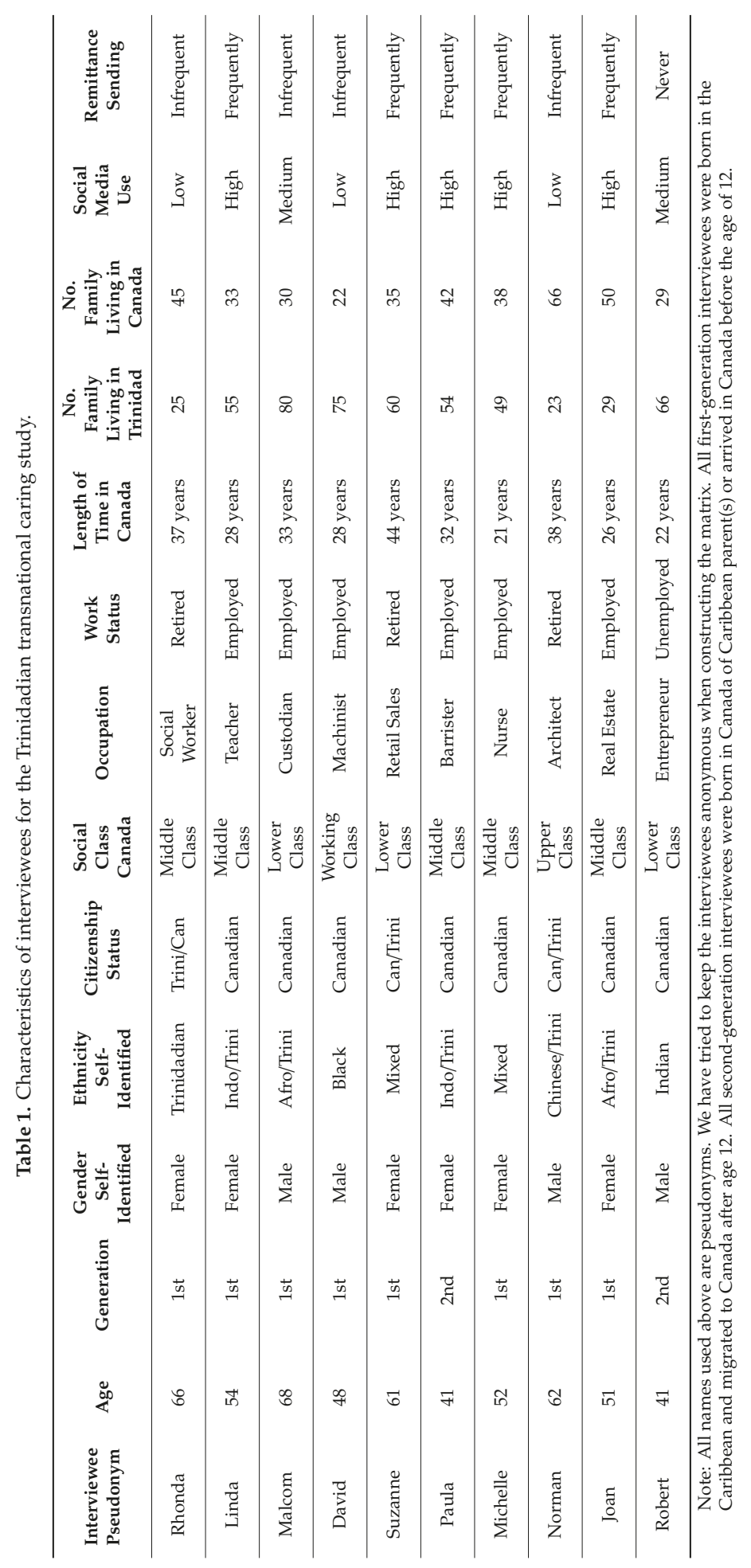




\section{Facebook and WhatsApp Use in the Trinidadian Diaspora}

Of the thirty five questions from the online surveys (2012 and 2015), some interesting trends were found in the way Trinidadians used Facebook and WhatsApp. Almost half of the respondents opened a Facebook account in the time frame 2008 to 2013. Given the fact that Facebook only became accessible to the general public in 2006, it makes this group of respondents a fairly seasoned early adopter group of Facebook users ${ }^{4}$. Most of the respondents in both surveys reported accessing Facebook from their home; others reported using their work computer as a location to check their account. Forty-five percent of respondents in the 2012 survey reported using WhatsApp whereas by 2015 eighty-two percent of respondents reported regularly using WhatsApp. This increasing trend parallels the enormous global growth of WhatsApp usage since its launch in 2009. Most of the respondents checked their Facebook account at least once per day, or once per week. Overwhelmingly, the respondents to both surveys ranked themselves as very good, or good with respect to their knowledge of the workings of Facebook. In addition to Facebook, the other social media platforms most often used by these Trinidadian respondents were YouTube, Skype, and Twitter. The other sites used consisted of an array of different applications that included: Periscope, Snapchat, and Google Hangouts. The vast majority of the respondents also indicated that they would directly text message their friends and relatives on a regular basis. More than fifty percent of the respondents indicated that they received regular WhatsApp messages from family and friends living in Trinidad. Almost forty percent of the respondents indicated that they used FaceTime for communicating with a family member in Trinidad. Sixty percent of the respondents indicated that they had used Skype communication technology to connect with someone in Trinidad and Tobago.

Most of the respondents felt that Facebook was a unique social media platform because it allowed them the possibility of keeping track of old friends and acquaintances. Forty-seven percent of the respondents reported that they used Facebook to keep track of their family and kin network. These patterns fit with Winnicott's (1969) theory that immigrants living abroad often find a space to engage in activities, "that bridge the emotional gaps" created by their feelings of dislocation and loss (Ainslie 1998).

The respondents reported that they had certain preferential activities that they consistently engaged with on Facebook. The activities were in ranked order, checking the status of friends, viewing the photographs posted by family, friends and kin, checking the status of family members, sending email messages, and finally, updating one's own profile page and photos. The respondents who reported using WhatsApp on a regular basis indicated that they did so because it allowed them to have free and instant voice communication with friends and family members in Trinidad. Having that ability to use their existing smart phone as a device to learn the latest news or gossip from back home was ranked as very satisfying on the survey. These activities are not surprising given the way in which this group of respondents was tied into living transnational lifestyles. The respondents are both here and there, where time and space have been compressed by access to the modern conveniences of cellular telephones, the Internet, and inexpensive airline travel back "home" (Basch et al. 1994). The distribution of responses also suggests that this sample of Trinidadians was using Facebook as a tool for maintaining contact with their most important support networks of family and friends who lived in the Diaspora. This regular communication also acted as a temporary escape from the routines of life in a foreign country where many reported feeling alienated as foreigners. Having an ability to engage in these transnational activities with family, friends, and acquaintances seems to give the respondents a feeling of belonging and mattering to others both close and far away (Schlossberg 1989). By using Facebook as a tool to be able to check up on others from "back home" or in the Diaspora, Trinidadian migrants continue to be engaged in the construction of transnational social fields (Basch et al. 1994).

4 Facebook went public on 26 September 2006. After this date anyone 13 years and older with a valid email address could start an account. 
In terms of which of the respondents used Facebook or WhatsApp to connect with, there was a clear hierarchy of who they maintained regular communication with. That list varied by the age of those in the home country, the number of return visits the individual reported making, the individuals' self-reported experiences of racism in the country of settlement, and their self-reported socio-economic status. Respondents who had made regular return visits had the highest reported use of technology to remain in regular contact with family, kin, and fictive kin in the diaspora overall. Individuals who reported experiencing medium or high rates of exposure to racism or racist incidents at work on in their new communities also tended to report using Facebook, WhatsApp or other social media tools to communicate with family living back home in Trinidad. It appears that these individuals were using social media as a tool to stave off feelings of alienation and marginalization in their new countries of settlement. Respondents who felt they were middle or upper middle class in the Diaspora reported being the highest users of social media technology to stay in contact with relatives, friends and acquaintances from Trinidad. This middle class group seems to be self-burdened with the responsibility of being the international caregivers for anyone left behind in the home country. Having a mental rank order of extended kin, family and friends shows evidence of the theories put forth by (Sorensen and Vammen (2014), Dossa et al. (2017), Parreñas (2005a), Baldassar et al. (2006), and Reynolds (2004)) about transnational care chains. Eight-two percent of the respondents indicated a preference for establishing contact with family, friends, and acquaintances that are of Trinidad origin. They also reported that they accepted friend requests mainly from Trinidadian people they already knew or Trinidadian people they attended school with while growing up. The criterion that was used by respondents to accept friend requests were also quite interesting to note. Sixty-five percent of the respondents only became friends with someone that was kin or a fictive kin member, who they were once a close friend of, a person who went to the same school, or that they knew a family member who the respondent was close to. This pattern of carefully selecting who to re-friend, befriend or to communicate with using social media suggested that Trinidadians like other people on Facebook, are weary of strangers with nefarious intentions. Thus, just having the same ethnicity was not enough commonality to encourage a Trinidadian Facebook user to open their virtual "door" and allow a stranger to have access to their most intimate photographs, memories, or backstage aspects of their lives (Goffman 1956).

\section{Facebook and WhatsApp as Multi-Directional Transnational Care Bridges}

Multi-directional caring, satisfying feelings of obligation to friends, family and kin are all possible using Facebook features like real time video streaming, scrapbooking, or the posting of photos. WhatsApp was reported as an easy to use technology for real-time communication with Trinidad. These opportunities may be particularly significant since family and kin are readily available online at almost any time, and the social media tools make communication easy to accomplish. ${ }^{5}$ Such contacts may foster the development of family relationships, including friendships as well as long distance romantic relationships. ${ }^{6}$ The contacts allowed individuals to be in real time communication especially when a health crisis was unfolding for an older family member. By being able to communicate for free via an individual's smart phone was reported to be psychologically comforting.

It is with the theory of cultural mourning, obligation, and transnational lifestyles in mind that we set out to explore how current social media is facilitating a transnational bridge to connect members of the Trinidadian Diaspora and ultimately helping to provide long-distance care to members of the

5 Facebook, enables its users to present themselves in an online profile, accumulate "friends" who can post comments on each other's pages, and view each other's profiles. Facebook members can also join virtual groups based on common interests, see what classes they have in common, and learn each others' hobbies, interests, musical tastes, and romantic relationship status through the profiles.

6 According to Boyd and Ellison (2007), Social Networking Websites are "web-based services that allow individuals to (a) construct a public or semi-public profile within a bounded system, (b) articulate a list of other uses with whom they share a connection and (c) view and traverse their list of connections within the system. 
community who are aging. By acting as a communication bridge that is free and available twenty-four hours a day, social media like Facebook and WhatsApp help to facilitate reminisces about the nostalgic past and become a mechanism to maintain and solidify linkages of obligation and caring to family, kin, and fictive kin in the international Diaspora. In the next part of the paper we will focus primarily on the use of Facebook and WhatsApp as the social media platforms which are being used by members of the Trinidadian Diaspora to maintain links with family, kin, and fictive kin who are aging. How the transnational family care network operates using a combination of low cost smart phone calls, the opportunity to send instant text messages, and the use of social media is all evident from the reflections of Linda, a fifty-four year old Indo-Trinidadian who lives in Toronto but who has family spread out across the Diaspora. She said:

"In my family the hub is actually in three geographical locations. One is in Toronto, another is in Miami, and the third is of course in Trinidad. How we communicate is essentially through the telephone and sometimes social media. Social media means email or more recently through a network of Facebook friends and family. Through all of this technology, I am on top of family issues all the time. Cheap telephone calls mean that we can stay in touch anytime we want. Communication is constantly going back and forth on either side of the triangle, but essentially what happens is if a need is communicated from Trinidad, to let's say Miami, this message is quickly relayed to Toronto and then something is quickly organized and someone takes action. This is how we do it round the triangle. So if a need is here in Toronto, then of course you go to the States, then to Trinidad, then it comes back."

This Diaspora linkage means that Linda's relatives both young and old have a social safety net that cocoons them in family care "twenty-four hours a day and three hundred and sixty five days of the year." So long as members of her family are able to seamlessly communicate then they can come up with a solution to whatever happens in the family and from various locations. This was particularly so when Linda's mother became ill in Trinidad. An arrangement was made immediately for a family member in Miami to fly to the Port of Spain to assist their mother with admittance into a private hospital for her illness. On another occasion Linda's nephew in Miami suffered an injury from a motorcycle accident. Once the call went out from her sister, an older retired aunt from Toronto flew down to Miami to keep vigil at his bedside in the hospital. This transnational multi-generational care model seemed to exist for many of the families in this study. The model is dependent on fast, inexpensive and reliable communication services. This can involve varied combinations of communication modalities that includes text messages, telephone calls, live stream video through Facebook, and WhatsApp. Families can be using single or multiple channels of communication to stay on top of real time family problems in Trinidad or the Diaspora. Michelle a fifty-two year old mixed woman shared her use of WhatsApp on a regular basis at work.

"I used texting and WhatsApp every day to stay in touch with my best friend Rachel in Trinidad. When I am at work and I am bored at my desk I will text Rachel. On my lunch break we will WhatsApp call the whole hour. I will find out about the latest murder, crime bust, gossip or fete!! Rachel and I have been friends since we were 12 years old and going to St Joseph Convent. I moved to Canada twenty-one years ago but I go back every year for Carnival. Since WhatsApp is free, we have no problem talking for hours. I can also ask Rachel to check on my old uncle Dave who lives alone in Diego Martin but he is not too far from Rachel's workplace."

It was not uncommon to hear stories of family sacrifice for the care of the older and younger members of the households, despite their geographical location or economic circumstance. This was also the situation for Rhonda a sixty-six year old Trinidadian living in Toronto. Her older sister Jean was reported to be the hub of a transnational care chain that included London, Toronto, and, the Port of Spain. Her older sister Jean would act as the "quarterback" who would orchestrate the family response 
when something came up. Rhonda is now using Facebook as her latest tool to ensure that everyone in the family is aware of each family member's needs or accomplishments. Rhonda said:

"Facebook acts as the catalyst for our international families' communication. My sister Jean in London, England who is now in her 70s and is the main spoke in the hub. She retired five years now but for some reason she got onto Facebook with her own children. She went from there to be the family historian and keeper of all photos and family stories. Jean does not move around on airplanes anymore but she uses the technology to know everyone's business. To some of us it's annoying but when you think about it, it's really our older sister Jean's way of caring for all of us. When she knows something is up, you can expect a phone call fairly quickly."

A similar transnational health story was told to us by David a 48-years-old African-Trinidadian male. His aunt was diagnosed with a terminal illness but because the family could all be virtually part of her chemotherapy treatments then it was much easier to find closure when she died of cancer a few months later. David says:

"Since I got my iPhone 5, I have been using FaceTime and WhatsApp with my cousins in Trinidad. We are in touch on such a regular basis I sometimes think that we are both living in Toronto. This new social media technology was especially helpful last year when my aunt Inez who lives in Guelph was diagnosed with pancreatic cancer. I could use FaceTime and WhatsApp with my cousin to keep my mother in Toronto updated on all the treatments her sister was having. I would then WhatsApp my uncle in Trinidad status updates about her treatments. The sad part is that aunty Inez died five months after the diagnosis. I think the technology made her passing much easier on everyone because we saw her right up till the end and we knew everything that was going on treatment wise. We could emotionally support each other using the technology and in some ways I think it made us less sad because we all had a sense of closure once the cancer took her life."

Overwhelmingly, we heard from the interviewees that Facebook has become an important tool for connecting and reconnecting people with their Trinidadian family, kin, and friends in the international Diaspora. The telephone both landline and cellular networks, continue to be the most important communication tool due to the fact that family members in the Diaspora do not all have high speed fiber optic internet cable connections. Another growing trend was to send text messages to family and friends for immediate status updates. The respondents also spoke in endearing terms about live stream video options, scrapbooking, and the posting of nostalgic or funny photos as ways to develop and maintain a caring relationship with family, kin and fictive kin spread out in the Diaspora. Having an ability to access this relatively free technology meant for many respondents, that they could better cope with feelings of cultural mourning, alienation and feeling marginalized in locations where they were considered as the perpetual "outsider" despite the length of time they have lived in their new country of settlement. Evidence of experiencing racism in the Diaspora was evident from the results of both surveys we conducted. Almost sixty-eight percent of the respondents reported having experienced some form of racism or discrimination in the place they lived in the Diaspora.

From nine out ten of our interviewees, it was clear that the most important feature that Facebook has to offer them is the ability to share nostalgic and current photograph updates that recorded celebrations and other special times. The older photographs were seen as a "time machine" that psychologically transported individuals back to their early fond memories of family, friends, or events. According to Michelle, the photographs she views daily on Facebook allow her to experience a sense of mattering and belonging to a culture and group that was once close in terms of proximal location (Schlossberg 1989). The photographs also helped other individuals to alleviate feelings of alienation and marginalization in the Metropolis of Toronto. This was certainly what we heard from Paula, a forty one year old Indo-Trinidadian woman who has lived in Canada for thirty-two years. Paula said: 
"Facebook is a great means of communication and picture sharing. It's been great finding old friends and being in touch with family all over the world. Normally you wouldn't be able to keep so in touch with the people who have been a part of your life whether it be from school days or present day. Facebook allows me to keep my finger on the pulse of what's going on in my family .... When you're homesick it helps you feel connected, sometimes as though you're still there ... Pictures posted, FaceTime and chat on Facebook are the most important features for me to show my love."

Another important function that Facebook and social media provide for many Trinidadians is fulfilling the void of cultural mourning. Seven of the ten respondents felt that logging into their Facebook account and reading a status update from a friend who was making a reference to family, food, music, or a short video taken at a fete (party) provided a much needed feeling of a virtual connection to being back "home". Trinidadians living in the Diaspora seem to use Facebook as a virtual space to engage in activities that help to bridge the emotional gaps created by their feelings of dislocation and loss (Ainslie 1998). This was evident in the sentiment voiced by Michelle, a fifty-two year old mixed Trinidadian-origin woman who reported getting a warm feeling when she heard something about back home mentioned on Facebook. Michelle said:

"Facebook keeps you current with what people back home are concerned about. A lot of nostalgia comes into play when I'm using Facebook. When someone mentions some local food they had for breakfast in a status update-like salt-fish buljol. It can put a smile on your face or bring back a warm memory .... It helps you keep up with everything that happens in T\&T the moment it happens. You do not feel so removed from the country when you live abroad for many years .... I use to host a game on Facebook I called 'Ex-Pat Question of the Day'. A fun trivia game open to my network of three hundred Trini's to remember words, people, and places in Trinidad."

Michelle also reported that her family sometimes used the live stream feature through Facebook or the video attachment in WhatsApp to send each other visual updates. These visual connections provided Michelle with a warm feeling of nostalgia and a temporary break from her monotonous routine in Canada. The visual technology gave Michelle a sense of belonging and an opportunity to participate in family events taking place in Trinidad. She tells us:

“My sister Verol has always been into celebrating her children's birthday by going all out in Trinidad. She will hire clowns, rent a bouncy house, go to Chucky Cheese or have over a house full of family and friends. I get to experience these family events because Verol uses Facebook live stream or she posts short cellular phone videos through WhatsApp as attachments. I can see my nieces and nephews blowing out candles or the speeches that our uncle always makes about the importance of family. The technology allows me to participate in the event because inevitably the camera goes around to each person and I can say hello ... it's not perfect but I get a real shot of true family love from those times."

Cultural mourning was also evident within our sample for the men and women who now have children who have grown up and left Trinidad. Norman a sixty-two year old Chinese Trinidadian was quite clear that in old age, he has come to be an avid user of Facebook so that he could keep in touch or re-connect with people he grew up with in Trinidad. He also felt that Facebook could help him to cope with the nostalgic longing for a connection with the past which was positive. Norman said:

“Facebook has been good for my friends who are aging gracefully ... ha ha ... . It's funny when I look at the photos my Trini posse posts, they are always young and vibrant and without gray hair. I guess that's human nature? We all want to look good and make others think that we are doing well especially as migrants. Despite our putting on a face on Facebook, I think that the technology allows us to know that we are all still alive and kicking with 
children, and grandchildren. Being alive and feeling like others care about us adds to one's life. It gives us a meaning that might otherwise not be there if we just lived out our day to day routine of retirement in Canada."

Reminiscing about the good old days through Facebook was a sentiment we heard from Suzanne. As a retired retail sales worker who lived in Canada for forty-four years, she felt that her internet connection at home was a "God send". She felt that the Internet allowed her to gain access to vast amounts of knowledge and experiences. She called it the "encyclopedia of everything" at the touch of a key. This was very positive for her because her entire working life was about meeting people in a department store, talking to them and then showing them something to purchase. This required a gregarious high energy "Trini personality" which Suzanne claimed to still have. Being retired, part of her identity linked to meeting and serving new people has withered since she lives in a condo building. With Facebook however, she has found new life. Suzanne said:

"Facebook takes me back to the good old days living in Princess Town as a youth coming of age. My village was mainly Indians living side by side and each of us living as a big family. Living as an older woman now in Toronto is very depressing. I have seen my children grow up in this cold country and not be very connected. I have seen us own a nice house in Canada but not really feel part of the community. I discovered Facebook a few years ago through my daughter who is a computer programmer. Seeta, my daughter created an account on Facebook for me and then got me connected with a woman I grew up with in Princess Town who lives in Miami. What's funny is that we all reminisce about roti, doubles, casscadura fish, oil down or other foods we remember eating or making. I think this is really a healthy way to build a community and keep track of people who were once really near and dear to us in life."

Facebook was also described by Malcolm as a "pumpkin vine" that connected his wife, Veronica's family in a transnational care chain. Malcolm's own family was not quite as competent in their use of technology or their desire to stay in touch with each other. This loose connection made Malcolm somewhat jealous of Veronica's ongoing ability to know something about everyone in her extended Diaspora family. Malcolm said:

"I am really jealous of the relationships my wife maintains through Facebook. My wife uses Facebook to know everything about her relative's status. I often look over her shoulder with envy because she has such a large array of people who care about her. Veronica is aware through the pumpkin vine of Facebook just what is happening in Trinidad. That includes keeping track of her oldest living relatives who are now in their $80 \mathrm{~s}$ and $90 \mathrm{~s}$. Veronica becomes aware in an instant when one of them is headed to the doctor or hospital or to take a treatment all because of her Facebook pumpkin vine."

Not everyone interviewed felt that Facebook was useful in their daily lives for maintaining transnational care chains. This negative sentiment about Facebook was most evident among men in our sample. A common sentiment was that participation in Facebook made these individuals susceptible to having their secrets or past digressions with members of the opposite sex back in Trinidad come back to haunt them. A desire not to reveal their current circumstance results in some men refusing to participate in social media. David a forty-eight-year-old African-Trinidadian referred to Facebook as "maco book" which is a colloquial phase that translates as being overly mindful of other people's personal business. David said:

"I do not use Facebook nor do I have any intention of doing so. I have resisted numerous offers to join any of these networks better known as e-macos... The one thing we might conclude so far is that "Facebook" and other such social media is really an age-bound thing. Old fellas like me shy away from the rapid-moving technological changes for fear of showing 
up our incompetence or we don't like that plenty people know my business, so I closed down the account... I don't do very much outside of that because I have no interest in persons knowing my personnel business. If they would like to find out about me, they need to use traditional methods like visiting or calling me."

Second generation Trinidadian origin men and women tend to be avid users of Facebook and WhatsApp as tools to get in touch with their family and friends scattered throughout the Diaspora. Facebook and WhatsApp allowed these younger people to ask and answer questions about where they came from, who their ancestors were, and the growing up experiences of their mothers and fathers. WhatsApp gave them the ability to attach short videos to their text messages. The short videos gave more meaning to what they were seeing in real time. For example a christening, a birthday celebration, or a fete could be videoed and then added to an email message or a text. The opportunity to use Facebook to connect with their past also gave many of our interviewees a feeling of belonging and mattering in real time ${ }^{7}$ (Schlossberg 1989). What was also interesting was the language code switching that was being done in the typed comments and posts in a combination of patios creole and standard English. Robert a forty-one year old Indo-Trinidadian Canadian certainly articulated these feelings about the use of Facebook as the technology which gave him an instant connection with family and kin who are located throughout the Diaspora. Robert said:

"Facebook gives the younger generation a chance to know and keep in contact with their family abroad like me. I like to keep in touch with the pace of things in Trinidad, especially my cousins who still live there ... . I like how my Trinidadian friends and family use Trinidadian lingo and refer to Trinidadian places and things and makes me feel I am still part of the island and its culture. Facebook allows me to send out likes to things my cousin posts. Over the years our relationship has grown stronger because he knows that I visit his page, comment on his political posts."

The second generation also used their Facebook account to keep in touch with important family members who had returned to Trinidad after having lived in Canada for a long period of time. In this case Facebook acts as the medium to facilitate the construction of transnational social fields that provide long distance care chains for family, kin and fictive kin (Sorensen and Vammen 2014; Dossa et al. 2017). This was certainly the case for Paula, a forty-one year old Indo Canadian-born Trinidadian whose favorite uncle moved back to Trinidad after having retired and lived in Canada for thirty-five years. Paula grew up with her mother in a single headed household in Toronto. When her uncle Rolly announced his intention to return to Trinidad to live, the news was devastating because her uncle had always been like a father to her while she was growing up in Toronto. Paula has turned to Facebook and other social media to stay in contact with her uncle Rolly. She reports getting advice and keeping up with Trini culture whenever she talks to her Uncle Rolly. Paula said:

"My uncle Rolly left Canada in 2010 for Trinidad. I thought that my life would change since uncle Rolly was like my dad. Lucky for us, Facebook has allowed me to still get advice from him and also to share my accomplishments at work. We exchange photos and talk to each other on Skype all the time. I have allowed him full access to my posts and photos so he knows everything. It's funny I think uncle Rolly knows more about me and my friends now than he did when he lived in Toronto. For us Facebook has ensured that our relationship remains solid because he can still help me out when I need him. I guess I also keep him connected to the rest of the family in Toronto."

7 Caribbean sojourners grew up in a world back "home" where life was different in that they knew their neighbors and they felt connected to their neighborhood through a shared feeling of mechanical solidarity. Living in Diaspora cities outside of the Caribbean region, individual contributions often go unrecognized; there is no real sense that their life is significant or meaningful to others. This often leads to feelings of alienation and not belonging in a predominately "white" culture. 


\section{Conclusions}

Despite being separated by great geographical distances, the transnational Trinidadian Diaspora community has managed to stay in regular communication using conventional means such as letter writing, phone calls, and telegrams. In the twenty-first century, this communication has become more real-time and relies on the most sophisticated internet technology. The purpose of communication is the same as in earlier times. The Diaspora is desirous of maintaining a transnational bridge that connects individuals across long distances and provides family members a feeling of psychological well-being as well as, real-time help in sickness or in times of economic need.

Staying in contact using a Facebook platform or the WhatsApp network has become the latest means to maintain a psychosocial feeling of mattering and to help buffer the effects of mourning and nostalgia for back "home". As new technologies like Twitter, and FaceTime become more readily utilized and mainstream both in the "home" and in metropolitan countries, it will affect the ways Trinidadian people stay in touch and provide transnational social and psychological care to family and kin.

Despite being an exploratory study, the data presented in this paper suggest that Trinidadian people in the international Diaspora are using social media applications like WhatsApp, Facebook, YouTube, and Skype to communicate and stay updated with each other. Currently, landlines and cellular telephones (texting) are by far the least expensive and most used technological mediums to remain in immediate contact. Social media platforms are changing the way that the Trinidadian Diaspora does "kin work" and communicates with friends and family about what is happening in the region and worldwide. The research from this paper suggests three preliminary findings: firstly, social media platforms like Facebook and cellular phone applications like WhatsApp are working as tools for Trinidadian people in the Diaspora to help alleviate feelings of alienation and marginality in host cultures; secondly, social media is acting as a transnational care bridge that connects familiar cultural values and practices and helps to alleviate feelings of cultural mourning; and finally, social media platforms are increasingly being used to solidify linkages of obligation and provide transnational caring to family and kin. With every new social media innovation being introduced in the marketplace, it does not take long before its adopted and it becomes mainstream. The main criteria for its adoption seems to be the cost, the ease of use and if it can be downloaded onto existing smart phone or computer devices.

Social media seems to fit directly into the transnational orientation for Trinidadian migrants living in the Diaspora because it provides them with a means to communicate across vast distances in real time. Social media platforms also seem to have given Trinidadian migrants a feeling of agency that helps them to avoid feelings of object loss and cultural alienation. This acquisition of agency is particularly important for some Trinidadian immigrants who have felt powerless to have a voice in the global public square. Undoubtedly, the cyber space world of the Internet and the use of social media platforms have given the Trinidadian Diaspora a real-time virtual connection to family, kin, and friends. As a consequence, this acts as a therapeutic, social and psychological means for Caribbean-origin people to be able to alleviate their feelings of loneliness in their diasporic locations.

As social media evolves there is much need for new research about this topic and looking at ways to understand how the Trinidadian Diaspora will use social media in order to maintain a bridge to those elderly and young left behind or those individuals who are sick and in need of family assistance in London, Miami or New York. The applications currently existing within most social media like Facebook, WhatsApp, Twitter, Skype and YouTube have the potential to make life more tolerable for Trinidadians who may be located in spaces where they are racialized and alienated from the dominant White European, Canadian and American narrative that sees them as the perpetual unwanted "problem" foreigner.

Author Contributions: The authors shared an equal contribution to the completion of the study and the writing of the manuscript.

Funding: This publication was undertaken without any external funding source. 
Conflicts of Interest: The authors declare no conflict of interest in writing this manuscript.

\section{References}

Ackers, Louise, and Helen Stalford. 2004. A Community for Children? Children, Citizenship and Internal Migration in the EU. Aldershot: Ashgate.

Ainslie, Ricardo. 1998. Cultural Mourning, Immigration, and Engagement: Vignettes from the Mexican Experience. In Crossings: Mexican Immigration in Interdisciplinary Perspectives. Edited by Marcelo Suarez-Orozco. Cambridge: Harvard.

Alicea, M. 1997. A Chambered Nautilus. The Contradictory Nature of Puerto Rican Women's Role in Social Construction of a Transnational Community. Gender \& Society 11: 597-626.

Asal, Houda. 2012. Community Sector Dynamics and the Lebanese Diaspora: Internal Fragmentation and Transnationalism on the Web. Social Science Information 51: 502-20. [CrossRef]

Baldassar, Loretta, Cora Vellekoop Baldock, and Raelene Wilding. 2006. Families Caring across Borders: Migration, Ageing and Transnational Caregiving. London: Palgrave McMillan.

Baldock, C. 2000. Migrants and Their Parents. Journal of Family Issues 21: 205-25. [CrossRef]

Barrow, Christine. 1996. Family in the Caribbean: Themes and Perspectives. Princeton: Marcus Wiener Publishing.

Barrow, Christine. 2010. Caribbean Childhoods Outside, Adopted or Left Behind Good Enough Parenting and Moral Families. Jamaica: Ian Randle Publications.

Basch, Linda. 2001. Transnational Social Relations and the Politics of National Identity: An Eastern Caribbean Case Study. In Islands in the City: West Indian Migration to New York. Edited by Nancy Foner. Berkeley: University of California Press, pp. 117-40.

Basch, Linda, N. Schiller, and C. Blanc. 1994. Nations Unbound. Langhorne: Gordon \& Breach.

Becker, Howard. 1960. Notes on the Concept of Commitment. American Journal of Sociology 66: 32-40. [CrossRef]

Boyd, Diana, and Nicole Ellison. 2007. Social Network Sites: Definition, History, and Scholarship. Journal of Computer-Mediated Communication 13: 80-102. [CrossRef]

Brettell, Caroline. 2007. Migration and Economy: Global and Local Dynamics. Anthropological Quarterly 80: 629-33.

Bryceson, D., and U. Vuorela. 2002. Transnational Families in the Twenty First Century. In The Transnational Family. New European Frontiers and Global Networks. Edited by D. Bryceson and U. Vuorela. Oxford: Berg Publishers, pp. 3-30.

Burman, Jenny. 2002. Remittance; Or, Diasporic Economies of Yearning. Small Axe 12: 49-71. [CrossRef]

Carling, Jørgen, Cecilia Menjívar, and Leah Schmalzbauer. 2011. Central Themes in the Study of Transnational Parenthood. Journal of Ethnic and Migration Studies 38: 191-217. [CrossRef]

Cohen, Robin. 1997. Global Diasporas: An Introduction. Seattle: The University of Washington Press.

De Haas, Hein. 2010. Migration and Development: A Theoretical Perspective. International Migration Review 44: 227-64. [CrossRef]

Di Leonardo, Micaela. 1987. The Female World of Cards and Holidays: Women, Families and the Work of Kinship. Journal of Women in Culture and Society 12: 440-53. [CrossRef]

Dossa, Parin, Cati Coe, Neda Deneva, and Yanqiu Rachel Zhou. 2017. Transnational Aging and Reconfigurations of Kin Work. New Brunswick: Rutgers University Press.

Ellison, I. 1985. Counseling West Indian Immigrants: Issues and Answers. In Inter Cultural Counseling. Edited by Ron Samuda and Ann Wolfgang. New York: Hogrete.

Enteen, Jillana. 2006. Spatial Conceptions of URLs: Tamil Eelam Networks on the World Wide Web. New Media $\mathcal{E}$ Society 8: 229-49.

Fajnzylber, Pablo, and J. Humberto López. 2008. The Development Impact of Remittances in Latin America. In Remittances and Development: Lessons from Latin America. Washington: World Bank, pp. 1-19.

Finch, Janet, and Jennifer Mason. 1990. Filial Obligations and Kin Support for Elderly People. Ageing and Society 10: 151-75. [CrossRef]

Finch, Janet, and Jennifer Mason. 1993. Negotiating Family Responsibilities. London: Rutledge.

Foner, Nancy. 1997. What's New about Transnationalism? New York Immigrants Today and at the Turn of the Century. Diaspora 6: 355-75. [CrossRef] 
Glick, J. E. 2010. Connect Complex Process: A Decade of Research on Immigrant Families. Journal of Marriage and the Family 72: 498-515. [CrossRef]

Goffman, E. 1956. The Presentation of Self in Everyday Life. New York: Doubleday.

Graziano, Teresa. 2012. The Tunisian Diaspora: Between "Digital Riots" and Web Activism. Social Science Information 51: 534-50. [CrossRef]

Grudz, Wellman, and W. Takheteyev. 2011. Visualizing Informal Learning Behavior from Conference Participants' Twitter Data. Osanto Model 55: 584-95.

Herrera, F. Lima. 2001. Transnational Families. In New Transnational Social Spaces. International Migration and Transnational Companies in the Early Twenty-First Century. Edited by Ludger Pries. London: Rutledge.

Ho, Christine. 1993. The Internationalization of Kinship and the Feminization of Caribbean Migration: The Case of Afro-Trinidadian Immigrants in Los Angeles. Human Organization 52: 32-40. [CrossRef]

Hochschild, A. R. 2000. Global Care Chains and Emotional Surplus Value. In Global Capitalism. Edited by W. Hutton and A. Giddens. New York: The New Press.

Hondagneu-Sotelo, P., and E. Avila. 1997. "I'm here, but I'm there": The Meanings of Latina Transnational Motherhood. Gender and Society 11: 548-71. [CrossRef]

Horst, Heather. 2006. The Blessings and Burdens of Communication: Cell Phones in Jamaican Transnational Fields. Global Networks 6: 143-59. [CrossRef]

Horst, Heather, and David Miller. 2006. From Cell Phone to Link-up: Cell Phones and Social Networking in Jamaica. Current Anthropology 46: 755-78. [CrossRef]

Ignacio, Emily. 2005. Building Diaspora: Filipino Cultural Community Formation on the Internet. New Brunswick and London: Rutgers University Press.

Jokhan, Mala. 2008. Parental Absence as a Consequence of Migration: Reviewing the Literature. Social and Economic Studies 57: 89-117.

Karim, Karim. 2003. The Media of Diaspora: Mapping the Globe. Research in Transnationalism. New York: Routledge.

Kilkey, Majella, and Laura Merla. 2014. Situating Transnational Families' Care-giving Arrangements: The Role of Institutional Contexts. Global Networks 14: 210-29. [CrossRef]

Klak, Thomas. 1998. Globalization and Neolibralism: The Caribbean Context. Lanham: Rowman \& Littlefield Publishers, Inc.

Kofman, Eleonore, and Parvati Raghuram. 2006. Women and Global Labour Migrations: Incorporating Skilled Workers. Antipode 38: 282-303. [CrossRef]

Lan, P. 2002. Subcontracting Filial Piety. Elder Care in Ethnic Chinese Immigrant Families in California. Journal of Family Issues 23: 812-35. [CrossRef]

Levitt, P. 2001. Transnational Migration: Taking Stock and Future Directions. Global Networks 1: 195-216. [CrossRef]

Levitt, P., and Lamba D. Nieves. 2011. Social Remittances Revisited. Journal of Ethnic and Migration Studies 37: 1-22. [CrossRef]

Lowenthal, David. 1972. West Indian Societies. London: Oxford University Press.

Marshall, Dawn. 1982. The History of Caribbean Migrations. Caribbean Review 11: 6-9.

Massey, Douglas, and Emilo Parrado. 1994. Migradollars: The Remittances and Savings of Mexican Migrants to the USA. Population Research and Policy Review 13: 3-30. [CrossRef]

Mazzucato, V., and D. Schans. 2011. Transnational Families and the Well Being of Children: Conceptual and Methodological Challenges. Journal of Marriage and the Family 72: 704-12. [CrossRef] [PubMed]

Mitra, A. 1997. Virtual Commonality: Looking for India on the Internet. In Virtual Culture. Edited by Steve J. Ones. Newbury Park: Sage Publication.

Nurse, Keith. 2000. Copyright and Music in the Digital Age: Prospects and Implications for the Caribbean. Social and Economic Studies 49: 53-81.

Okafor, Stanley, and Rex Honey. 1998. Hometown Associations: Indigenous Knowledge and Development in Nigeria. Dunsmore Rugby: Intermediate Technology Publications.

Olwig-Fog, Karen. 2002. A Wedding in the Family: Home Making in a Global Kin Network. Global Networks 2: 205-18. [CrossRef]

Olwig-Fog, Karen. 2012. The Care Chain, Children's Mobility and the Caribbean Migration Tradition. Journal of Ethnic \& Migration Studies 38: 933-52.

Orozco, Manuel. 2002. Globalization and Migration: The Impact of Family Remittances in Latin America. Latin American Politics and Society 44: 41-46. [CrossRef] 
Orozco, Manuel. 2004. Distant but Close: Guyanese Transnational Communities and Their Remittances from the United States. In Diálogo Interamericano, Informe Encomendado por la Agencia para el Desarrollo Internacional de E.E.U.U., AID. Washington: World Bank.

Panagakos, Anastasia, and Heather Horst. 2006. Return to Cyberia: Technology and the Social Worlds of Transnational Migrants. Global Networks 6: 109-24. [CrossRef]

Parreñas, R. 2005a. Long Distance Intimacy: Class, gender and intergenerational relations between mother and children in Filipino transnational families. Global Networks 5: 317-36. [CrossRef]

Parreñas, R. 2005b. Children of Global Migration: Transnational Families and Gendered Woes. Stanford: Stanford University Press.

Patton, M. 2002. Qualitative Research and Evaluation Methods, 3rd ed. Thousand Oaks: Sage Publication.

Portes, Alejandro, Luis E. Guarnizo, and Patricia Landolt. 1999. The Study of Transnationalism: Pitfalls and Promise of an Emergent Research Field. Ethnic and Racial Studies 22: 217-37. [CrossRef]

Reynolds, Tracey. 2004. Families, Social Capital and Caribbean Young People's Diasporic Identities, Families \& Social Capital ESRC Research Group. Working Paper Series, No. 11; London: South Bank University.

Reynolds, Tracey. 2005. Caribbean Mothers: Identity and Experience in the UK. London: Tufnell Press.

Reynolds, Tracey. 2006. A Comparative Study of Care and Provision Across Caribbean and Italian Transnational Families. Families \& Social Capital SRC Research Group. Working Paper Series; London, UK: South Bank University.

Rubenstein, Hymie. 1983. Caribbean Family and Household Organization: Some Conceptual Clarifications. Journal of Comparative Family Studies 14: 283-98. [CrossRef]

Schlossberg, N. K. 1989. Marginality and Mattering: Key Issues in Building Community. In Designing Campus Activities to Foster a Sense of Community. New Directions for Student Services. Edited by Dennis C. Roberts. San Francisco: Jossey-Bass, pp. 5-15.

Senyurekli, Aysem, and Daniel Detzner. 2009. Communication Dynamics of the Transnational Family. Marriage $\mathcal{E}$ Family Review 45: 807-24.

Simmons, Alan, and Dwaine Plaza. 2006. The Caribbean Community in Canada: Transnational Connections and Transformation. In Negotiating Borders and Belonging: Transnational Identities and Practices in Canada. Edited by Wong Lloyd and Vic Satzewich. Vancouver: University of British Columbia Press, pp. 130-49.

Smith, M. P., and M. Bakker. 2008. Citizenship Across Borders; The Political Transnationalism of El Migrante. Ithaca: Cornell University Press, 264p.

Sorensen, Ninna, and I. Vammen. 2014. Who Cares? Transnational Families in Debates on Migration and Development. New Diversity 11: 89-108.

Strauss, Anselm, and J. Corbin. 1990. Basics of Qualitative Research: Grounded Theory Procedures and Techniques. Newbury Park: Sage Publishing.

Tekwani, Shyam. 2003. The Tamil Diaspora. Tamil Militancy, and the Internet. In Asia Communication: Asia Encounters the Internet. New York: Routledge, pp. 175-92.

Vertovec, Steven. 1999. Conceiving and Researching Transnationalism. Ethnic and Racial Studies 22: 447-62. [CrossRef]

Vertovec, Steven. 2004. Cheap Calls: The Social Glue of Migrant Transnationalism. Global Networks 4: 219-24. [CrossRef]

Wilder, R. 2006. Virtual' intimacies? Families Communicating Across Transnational Contexts. Global Networks 6: 125-42.

Williams, Fiona. 2004. Rethinking Care in Social Policy. Janus 12: 6-24.

Winnicott, D. W. 1969. The Use of an Object. International Journal of Psychoanalysis 50: 711-16.

Wise, A., and S. Velayutham. 2006. Towards a Theory of Transnational Affect and Emotion. Working Paper No. 4 for Center for Research on Social Inclusion. Macquarie University, Sydney, Australia.

Zontini, E. 2004. Immigrant Women in Barcelona: Coping with the Consequences of Transnational Lives. Journal of Ethnic and Migration Studies 30: 1113-24. [CrossRef]

(C) 2019 by the authors. Licensee MDPI, Basel, Switzerland. This article is an open access article distributed under the terms and conditions of the Creative Commons Attribution (CC BY) license (http://creativecommons.org/licenses/by/4.0/). 


\title{
Article \\ Challenges and Strategies for Promoting Children's Education: A Comparative Analysis of Chinese Immigrant Parenting in the United States and Singapore
}

\author{
Min Zhou ${ }^{1, *}$ and Jun Wang ${ }^{2}$ \\ 1 Department of Sociology, University of California, Los Angeles, CA 90095-1551, USA \\ 2 School of Social Sciences, Nanyang Technological University, Singapore 639818, Singapore; \\ WANG1078@e.ntu.edu.sg \\ * Correspondence: mzhou@soc.ucla.edu
}

Received: 18 February 2019; Accepted: 11 April 2019; Published: 15 April 2019

\begin{abstract}
Confucian heritage culture holds that a good education is the path to upward social mobility as well as the road to realizing an individual's fullest potential in life. In both China and Chinese diasporic communities around the world, education is of utmost importance and is central to childrearing in the family. In this paper, we address one of the most serious resettlement issues that new Chinese immigrants face-children's education. We examine how receiving contexts matter for parenting, what immigrant parents do to promote their children's education, and what enables parenting strategies to yield expected outcomes. Our analysis is based mainly on data collected from face-to-face interviews and participant observations in Chinese immigrant communities in Los Angeles and New York in the United States and in Singapore. We find that, despite different contexts of reception, new Chinese immigrant parents hold similar views and expectations on children's education, are equally concerned about achievement outcomes, and tend to adopt overbearing parenting strategies. We also find that, while the Chinese way of parenting is severely contested in the processes of migration and adaptation, the success in promoting children's educational excellence involves not only the right set of culturally specific strategies but also tangible support from host-society institutions and familial and ethnic social networks. We discuss implications and unintended consequences of overbearing parenting.
\end{abstract}

Keywords: Confucian heritage culture; transnational family; new Chinese immigrants; education; Chinese parenting

\section{Introduction}

Confucian heritage culture values education and holds that a good education is the path to upward social mobility as well as the road to realizing an individual's fullest potential in life (Lam et al. 2002). In both China and Chinese diasporic communities around the world, education is of utmost importance and is central to childrearing in the family. In ancient China, the strong belief in learning is well illustrated in an old saying, "There are houses of gold in books." The traditional keju (科举) civil examination system, implemented in ancient China for more than two millennia, had enabled hundreds of thousands of individuals of rich or poor family backgrounds to succeed in attaining positions of power in the imperial court, which were formal status markers for the individual and a tremendous honor to his family. Abolished in late Qing Dynasty at the turn of the 20th century, the meritocratic keju system has a long lasting and persistence effect on contemporary Chinese education. All three levels of formal schooling — elementary, secondary, and post-secondary—emphasize homework marks and 
test scores. Students must meet the official standards of academic performance in order to advance grade levels. In the last year of senior high school, most students study hard to prepare for the national university entrance examination, or gaokao (高考). Gaokao is the most competitive examination that is considered to determine a child's life and career opportunities, earning potential, and even marriage prospects (Ash 2016).

Although it has been a constant source of stress for both children and parents, the exam-oriented educational system in China is widely accepted as a fair system of meritocracy enabling upward social mobility (Liu 2016). Parents prioritize children's education in childrearing. They invest enormous amount of energy and financial resources in children's academics and extracurricular activities to make sure that children excel in school, score high in competitive examinations, and get into the best universities.

In diasporic communities overseas, there has been equal, if not more, emphasis on children's education in the diasporic Chinese family. Chinese immigrant parents are uprooted from their familiar habitats. They encounter challenges in adapting and integrating into their host societies and are, in the process, pressured to restructure their habitus and develop strategies for effective parenting. Many Chinese immigrant parents claim that they have sacrificed for their children's better educational opportunities, career prospects, and life chances through emigration. They strongly believe that education is the only predictable and effective way for their children to achieve upward social mobility in a host society. Like their counterparts in China, overseas Chinese parents never hesitate to invest on children's education with their best efforts and resources, expecting that their children achieve the highest level of education possible as a means of helping move the family up to or maintain middle-class status and repaying parents (Zhou 2006).

Research has consistently shown that children of new Chinese immigrants, or xinyimin, ${ }^{1}$ generally do better in school than their native peers, as measured by GPA, grades, college attendance, and college graduation institutions, in countries such as the United States, Canada, the U.K., Australia, New Zealand, and Singapore (Abada et al. 2008; Archer and Francis 2006; Chung et al. 1997; Ho 2017; Kasinitz et al. 2009; Lee and Zhou 2015; Seah 2017; Sue and Okazaki 1990; Watkins et al. 2017). And their extraordinary academic success is often attributed to Confucian heritage culture or "tiger mom" parenting, the traditional Chinese way of childrearing of a strict and disciplinarian mother (Chua 2011; Chua and Rubenfeld 2014). However, less is known about how Chinese immigrant parents in different receiving contexts cope with challenges in the processes of immigration and adaptation, and how they overcome structural and cultural barriers in addressing their intense educational concerns and anxieties in the countries of resettlement. To fill this void, our current study examines how contexts matter for parenting, what immigrant parents do to promote their children's education, and what enables parenting strategies to yield expected outcomes.

The United States and Singapore are the two most preferred migration destinations for new Chinese immigrants. These two host societies differ significantly in contexts of reception—one Western and the other Eastern with strong Confucian heritage culture. A comparative study of immigrant parenting offers a unique opportunity to understand how culture is shaped by structure to influence children's educational outcomes. We argue that successful parenting involves not only the right set of culturally specific strategies but also tangible support from host-society institutions and familial and ethnic social networks. In the following text, we first offer a brief overview of new Chinese immigration to the U.S. and Singapore to highlight the variations on contexts of reception. We then examine the changing structure of the Chinese immigrant family. Thirdly, we examine how migration creates new challenges for parents regarding children's education. Fourth, we explain what immigrant parents

1 Referred to those who emigrated from mainland China after China implemented open-door policy and economic reform in December 1978. Xinyimin differ from their earlier counterparts in terms of socioeconomic backgrounds, sending and receiving contexts, and transnational linkages (Zhou 2017). 
do in respective host societies to successfully cope with these challenges. We conclude by discussing unintended consequences of over-bearing parenting.

\section{Methods and Data}

Our analysis is based on data collected from face-to-face interviews and participant observations in Chinese immigrant communities in Los Angeles and New York in the United States and in Singapore. Qualitative fieldwork, which included participant observations in Chinese schools, various afterschool programs, and community events and on-site non-structured interviews with parents, was conducted in Chinatowns and Chinese ethnoburbs in Los Angeles and New York over a period of ten years (2003-2013). In Singapore, 45 in-depth structured interviews with new Chinese immigrant parents were conducted during the period of summer 2018 to February 2019, each lasting about 60 minutes; in addition, observations in after schools and community events and short interviews on site were conducted during a longer span of time from 2014 to 2018 (mostly on weekends). In both the U.S. and Singapore, we employed the purposive snowballing method to recruit interviewees from socioeconomically diverse backgrounds while also participating non-intrusively in social media Wechat group discussions among concerned Chinese parents, including those in China, the U.S. and Singapore. We also conducted content analysis of Chinese language newspaper reports and education-related advertisements. We use pseudonyms when we quote interviewees' narratives.

\section{Contemporary Chinese Immigration: An Overview}

Since the late 1970s when China opened its door to the outside world, massive waves of Chinese emigration have surged onto the shores of all continents of the globe with little sign of subsiding (Zhou 2017). As of 2017, the number of international migrants from China reached 10 million, as estimated by the United Nations Department of Economic and Social Affairs. ${ }^{2}$ Although new Chinese immigrants at the turn of the 21st century are geographically dispersed in all parts of the globe, the majority has been resettled in developed countries of the Global North. While the United States takes the lion's share (25 percent of all xinyimin), Canada, Australia, New Zealand, the U.K., and some developed countries in Asia, such as Japan and Singapore, also experience tremendous influx (Zhou 2017). Why new Chinese immigrants emigrate in such high numbers and how they fare in their countries of destination upon arrival may be understood by multi-level factors pertaining to the context of exit and context of reception (Portes and Rumbaut 1990).

\subsection{Context of Exit}

In terms of the context of exit, the continually high emigration from China is a direct consequence of China's open door and is perpetuated by several structural factors. First, the economic reform has attracted enormous foreign investment to flow into China, of which more than three quarters of the foreign investment are from the Chinese Diaspora. The injection of ethnic Chinese capital in the 1980s not only greatly propelled China's economic takeoff, but also activated diasporic familial connections that had been dormant for many years and transnational social networks. Second, the Chinese government removed the institutional obstacles to population mobilities, including internal and international migrations, relaxed the requirements for obtaining passports, simplified the procedures for going overseas, and allowed Chinese citizens with diasporic relatives to legally emigrate. Third, China promoted its economic reform and modernization goals by implementing policies to support studying and training abroad. Since 1979, the government has sponsored hundreds of thousands of college students and visiting scholars abroad to study for advance degrees or for academic training and

2 United Nations Department of Economic and Social Affairs, http://www.un.org/en/development/desa/population/migration/ data/estimates2/estimates17.asp “Total International Migrant Stock," accessed on 22 January 2019. 
exchange. It has also allowed individual Chinese citizens to study abroad by self-financing. ${ }^{3}$ Fourth, overseas investment by Chinese state-owned enterprises and private firms has increased, especially after China joined the World Trade Organization (WTO) in 2001, which has further fueled emigration. These broad structural factors, coupled with the relaxation of immigration policies and economic globalization by many receiving countries, have constituted an important context of exit for Chinese emigration that differs significantly from earlier waves prior to World War II.

New Chinese immigrants in the U.S. and Singapore share the same context of exit. They show similar demographic and socioeconomic characteristics that are distinct from their earlier counterparts. First, new Chinese immigrants have diverse origins and socioeconomic backgrounds. They have arrived not only from traditional hometowns of overseas Chinese, i.e., Guangdong and Fujian, but also different provinces all over China. Second, unlike early immigrants who arrived with minimum education and few job skills, new Chinese immigrants tend to be hyper-selected in many developed countries of destination, which means that their percentage of college graduates is significantly higher than that of the general population both in China and in the country of destination (Lee and Zhou 2015). Highly skilled immigrants with at least 4 years of college education are 51 percent among all new Chinese immigrants in the U.S., and the corresponding statistic in Singapore is above 75 percent. Third, new Chinese immigrants have also shown diverse geographic patterns of resettlement. In the U.S. for example, though a small number of new immigrants cluster in Chinatowns or in the newly established ethnoburbs, the majority is spread out in middle-class white suburban communities across the country. In Singapore, they "melt" into the same neighborhoods as natives with no distinguishable ethnic enclaves. Fourth, new Chinese immigrants are more inclined to resettle abroad, making home in their countries of destination rather than returning home to China. Earlier immigrants were mostly sojourners who worked overseas to earn money with the goal of eventually returning home. Nowadays, though many new immigrants have numerous opportunities to practice transnationalism, they are mostly settlers, seeking to grow roots in their new homeland and integrate into the mainstream host society (Zhou 2017).

\subsection{Contexts of Reception}

In terms of context of reception, the U.S. is the number one destination for new Chinese immigrants, and Singapore is also one of the most preferred countries of destination in the world. Notably, there are significant differences between the two receiving contexts in immigration and integration policies, labor markets, socioeconomic and cultural environments, and the social position and organization of the diasporic communities vis-à-vis host societies.

The United States concentrates the largest number of new Chinese immigrants, absorbing more than a quarter of the total emigrants from China. The history of Chinese immigration in the U.S. dates back to the late 1840s. Early Chinese immigrants were mainly peasants from the 'siyi' (四邑) area of the Pearl River Delta region in Guangdong Province, China. They first arrived in the U.S. as laborers, working first in mines and then in building the most difficult part of the transcontinental railroad west of the Rockies (Chan 1991). Poor economic conditions in the late 1870s and the fear of the yellow peril made Chinese laborers targets of nativism and racism (Chan 1991; Saxton 1971). Exacerbated by anti-Chinese agitation, the Congress passed the Chinese Exclusion Act in 1882 to restrict Chinese immigration. Consequently, Chinese immigrants built Chinatowns for self-protection and reorganized their sojourning lives within these socially isolated enclaves on the West Coast, such as in San Francisco and Los Angeles, and in other major urban centers to which many had fled, such as New York and Chicago (Chan 1991; Zhou 1992). Within Chinatown, levels of coethnic interaction

3 Self-financed students were mostly college students in the 1980s and 1990s, and their funding mainly came from overseas relatives. Since the late 1990s, many families in China that have achieved upper-middle class status have sent their children to study abroad even at middle school and high school levels. 
and solidarity were high. Chinese immigrants, mostly male sojourners, and ethnic business owners were interdependent and were both tied to various family or kinship associations, hometown or district associations, and tong or merchants' associations (Zhou 1992, 2006). Even after the Chinese Exclusion Act was repealed in 1943 and the U.S. and China became allies in World War II, the diasporic Chinese community and its members were largely excluded from participation and assimilation in American life.

In 1965, the U.S. Congress passed the Hart-Celler Act of 1965, which abolished the national origins quota system and gave priority to family reunification and the importation of skilled labor. The U.S. immigration policy reform, intertwined with the normalization of Sino-US foreign relations in 1979 and China's open door, has led to the continuous and exponential growth of new Chinese immigrants to the U.S. over the past 40 years (Zhou 2017). The influx of new Chinese immigrants has changed the structure and composition of Chinese America. The U.S. censuses show the number of ethnic Chinese population increased from 240,000 in 1960 to more than 1.6 million in 1990, increased further to more than 3.8 million in 2010; it has exceeded 5 million in 2016 (Zhou 2017). Chinese Americans, more than two-thirds foreign born, are the largest Asian ethnic group, but they only account for about one percent of the general U.S. population. However, their socioeconomic backgrounds are much diverse, with nearly half of the foreign population attaining at least a bachelor's degree and more than 40 percent holding a professional occupation.

New Chinese immigrants arrive in a much more open American society with all forms (racial-ethnic, gender, age, etc.) of discrimination outlawed. At the group level, Chinese Americans have also made tremendous inroads into mainstream America, showing extraordinary socioeconomic achievements with average levels of education, occupation, and income higher than non-Hispanic whites (Pew Research Center 2012). The rising enrollment of ethnic Chinese students in elite schools, Chinese American academic excellence, and their overrepresentation in professional occupations in the labor market have led to a new stereotype of "model minority," which goes hand in hand with the familiar stereotypes of the "unfair competitors," "unassimilable aliens," and "forever foreigners" (Saito 1997; Tuan 1998; Zhou 2004). The diasporic Chinese community is thriving with a strong ethnic economy and ethnic pride; it has, however, evolved into an ethnic American minority group. Despite its seeming success, it is still marginalized in American's racial stratification system, given that mainstream American society is still heavily influenced by Anglo-Saxon Protestant culture and dominated by European-origin white majority group.

Unlike the U.S., the history of Chinese immigration to Singapore is longer and much more complex; it originated from the maritime trade to Southeast Asia conducted by Chinese merchants and traders from Guangdong and Fujian provinces, who had been there long before the European colonists set foot in the region (Wang 1993). In 1819, Sir Raffles landed in Singapore on behalf of the British East Indian Company, and planned and rapidly developed Singapore into a free trading port in Southeast Asia. During this period of time, the Chinese started to migrate to this island off the southern tip of the Malay Peninsula. From the establishment of the British colony of Singapore in 1819 to the beginning of World War II, the British colonial government adopted a free immigration policy, which led to a continuous increase of Chinese immigrants. According to statistics, the number of Chinese immigrants in Singapore increased from about 3000 in 1820 to 50,000 in 1860, accounting for 60 percent of the total population in Singapore (Meagher 2008, p. 134). After World War II, the Chinese population in Singapore increased to 730,000, accounting for more than three-quarters of the total population. But from the end of World War II to 1990, immigration from mainland China ebbed to a trickle.

Singapore became an independent nation-state in 1965. After independence, Singapore only took three decades to transform itself from a "third world" country to a fully industrialized and modernized country. In the late 1980s, the city-state encountered two daunting demographic challenges-the shortage of scientific and technological talents and the sharp decline of natural growth rate of the population, which threatened the country's competitiveness in economic globalization (Zhou and Liu 2016). Therefore, the government urgently adjusted its economic and 
immigration policies to attract high skilled immigrants. A direct policy outcome was the sudden, rapid, and continuous growth of the total population, due primarily to international migration. According to 2018 statistics, it had a population of 5.64 million, of which 62 percent were citizens, 9 percent permanent residents (PR), and 29 percent foreigners holding temporary work visas (Singapore Department of Statistics 2018). The proportion of immigrants would be much higher if the number of naturalized citizens was taken into account.

Xinyimin is a term that Singaporeans, in particular, use to distinguish themselves from the new Chinese immigrants arriving in the country after 1990. While Singapore does not explicitly prefer any one ethnic group when it comes to attracting foreign talents and international students, it is believed that the government does prefer Chinese immigrants in order to replenish the potential decline of the ethnic Chinese population due to the extremely low fertility rate among Singaporean Chinese women (Tan 2003). One way was to directly recruit Chinese students who have received advanced degrees in Western countries, and the other was to offer generous scholarships to high school students in China to study in Singapore in the hope that those Chinese students would stay in Singapore after receiving college or advanced degrees at Singapore universities (Zhou and Liu 2016). Singapore's mainstream newspaper, The Straits Times, reported that the number of new Chinese immigrants rose from a couple of thousands in the early 1990s to more than one million in 2008. The new Chinese immigrants in Singapore include both skilled professions and low-skilled workers. Those who have obtained permanent resident (PR) status or Singaporean nationality are mostly students, professionals, and business migrants (Zhou and Liu 2016).

Singapore is a multi-racial nation-state, in which ethnic Chinese constitute the majority, at 74 percent of the total population with Malays and Indians at 13 percent and 9 percent, respectively (Singapore Department of Statistics 2018). The government designates English, Chinese, Malay, and Tamil as the official languages, but English is most commonly used in the government, international business, science and technology, and education. English is preferred and emphasized, as the government believes that the English language will improve the country's international competitiveness, while playing a bridging role between different racial and ethnic groups.

Singaporean society is deeply influenced by the British colonial heritage and the history of international migration, where Western and Eastern cultures blend with each other. Singapore's political system is established based on the British parliamentary democracy, which places emphasis on meritocracy in the selection and appointment of government officials and civil service personnel (Bellows 2009; Quah 2010). Meritocracy is also very much emphasized in the recruitment of professionals and managers in the private sector. Although it claims to be multicultural, however, the government deliberately constructs a "Singaporean" national identity based on ethnic equality, which inadvertently excludes new immigrants. In addition, it is noticeable that native-born Chinese Singaporeans dominate the country's political, economic, and social arenas and implicitly constitute the core ethnic group of the mainstream society (Zhou and Liu 2016). Members of this core group, though sharing the same cultural heritage and tradition, often distinguish themselves from the new Chinese immigrants culturally in language, ${ }^{4}$ values and norms, and behavioral patterns. Despite proactive government policy to promote immigrant integration, the rapid growth and visibility of new Chinese immigrants has caused widespread anxiety, discontent, and even xenophobia among native Singaporeans, especially Chinese Singaporeans, as they view these newcomers as the different "other"5 - unfair competitors taking jobs away from natives and a cultural threat to the cohesiveness of the "multicultural" society (Yeoh and Lin 2013; Liu 2012). It is noteworthy that this particular "other" identity imposed upon

4 While most new Chinese immigrants speak standard Mandarin (putonghua), Singaporean Chinese speak Chinese with a heavy local accent, influenced by Malay, and Chinese dialects of Hokkien, Cantonese, Teochew, and Hainan.

5 In government statistics, the "other" is an official racial category, referring to Eurasians, Europeans, and other nationalities who are natives or are rooted in Singaporean society. The CMIO (Chinese, Malay, Indian, and Others) model makes up the dominant organizing framework of race. 
new Chinese immigrants in Singapore, where the dominant group is ethnic Chinese, is by nature the same as the "other" identity imposed on Chinese Americans in the U.S., where the dominant group is non-Hispanic white. In both cases, "othering" serves as a key mechanism of social exclusion.

\section{Changes in the Chinese Immigrant Family}

\subsection{The Changing Chinese Immigrant Family in the United States}

Migration breaks up the traditional Chinese family, which has a multi-generational structure with extensive networks of social support and control, and weakens parental authority to guide and discipline children due to language and cultural barriers. The immigrant family tends to be restructured in the form of the two-generation nuclear family.

In the U.S., Chinese immigrants were segregated in bachelors' societies in Chinatowns prior to World War II. Because of the restriction of female migration, the male to female sex ratio was seriously imbalanced, showing 110:1 in 1900, and 6:1 in 1940 (Zhou 1992). Many Chinatown "bachelor" workers were actually married but left their wives, children, and parents behind in their home villages in China, leading to a distorted structure in the Chinese immigrant family-the split household (Glenn 1983). In old Chinatowns, whether in split household or nuclear families, individuals and families were well connected to the ethnic community and highly dependent on it for social, economic, and emotional support while subject to its control. Children grew up in a quasi-extended family environment and were surrounded by and under the watchful eyes of many "grandpas" and "uncles" who were not related by blood (Zhou 2006). They lived segregated lives in the ethnic enclave, speaking fluent Chinese, mostly in local dialects such as Cantonese, going to Chinese schools, working in Chinese-owned businesses, and interacting intimately with other Chinese. The larger society looked down on the Chinese and set barriers to keep them apart, such as segregated schools and workplaces. Many children wished to become like other American children but faced resistance from the larger society as well as from their own families. The Chinese families tied their children to Chinatown and its ethnic institutions, with the Chinese school being the most important one, to shield them from being harmed by overt discrimination. The children conformed to the values and behavioral standards prescribed by the community. They were considered either "good" kids-loyal and guai (obedient)—or "bad" kids—disrespectful and bai-jia-zi (family failure). Consequently, despite much adolescent rebellion and intense generational conflicts within the family, the children often found themselves going full circle back to ethnic networks without much room to act up and eventually becoming nobody but Chinese. Although there are potential intergenerational and cultural conflicts within the family, the ethnic social environmental and social relationships of the ethnic community helped mitigate these conflicts (Zhou 2006).

In the 1960s, the U.S. civil rights movement resulted in the passage of the Civil Rights Act of 1964, which ended segregation in public places, outlawed employment discrimination, and ensured equal opportunities in education, employment, and housing for socially marginalized groups. And in 1965, Congress relaxed and reformed the immigration law to prioritize family reunification. The gradual opening up of the larger society is crucial for Chinese immigrants and their children to integrate into the mainstream society and achieve upward social mobility. New Chinese immigrants arrived in a more favorable context of reception than their earlier counterparts. Since the 1980s, there has been a significant change in the Chinese immigrant family, in that the nuclear family has replaced the split household family to become the dominant structure. Moreover, new Chinese immigrants are no longer trapped in Chinatown and confined to jobs in the ethnic enclave economy. They are able to resettle in white middle class suburban communities and obtain employments in the mainstream labor market.

However, unlike many white middle class families where fathers are the main breadwinners and mothers homemakers, the majority of Chinese immigrant families are two-wage-earner families. Because of disadvantages associated with immigrant status, many Chinese immigrant men experience downward mobility and have difficulty getting jobs that secure their role as main breadwinners. 
Women have to work outside the home, and many contribute equally, if not more, to the family while continuously taking the principal responsibility for childrearing. Regardless of socioeconomic background, most children of new Chinese immigrants live in families with both parents working full-time and some at several jobs on different shifts. Without the help of grandparents, relatives, and other close friends, some of these children become latch-key children, staying home alone after school hours. Changes in parent-child relations are also noteworthy, particularly in families where the parents have low levels of education and job skills and speak little or no English. Often these parents have to depend on their children as translators and brokers between the home and the outside world, which severely curtails parental authority (Zhou 2006).

\subsection{The New Chinese Immigrant Family in Singapore}

The early Chinese diasporic community in Singapore also experienced the similar situation of the "bachelor society" of Chinatowns in the U.S. Throughout the 19th century and the 20th century prior to World War II, the Chinese diasporic community was dominated by the able-bodied male. The male-to-female ratio was 14:1 in 1860 and 4:1 in 1901, despite the fact that women were allowed to immigrate by law (Saw 1969). Since the end of World War II, the Chinese community started to transition from sojourning to long-term settlement and from diasporic (with a homeland to return to) to native community (Zheng and $\mathrm{Hu}$ 2018). As the ethnic population grew, the sex ratio was gradually balanced, at 113 men per 100 women in 1947, and thereafter the number of native nuclear families gradually increased (Freedman 1957, p. 25). In the mid-1950s, nuclear families made up one third of all households and single-person households made up another one third; and the average household size was estimated to be 3.7 (Goh 1956; Kaye 1960; Tan 1965). During the 1950s, many Chinese families, native or immigrant alike, lived in poverty and in overcrowded housing (Warren 1986).

Since independence in 1965, Singapore has aggressively pursued modernization and promoted family cohesion as a core value for nation-building and economic development (Chua 1995; Hill and Lian 1995). In 1965, the natural population growth rate fell from 3.4 percent in 1957 to 2.5 percent (LePoer 1989). The government since then has adopted an interventionist strategy in formulating population and family policies. For example, in 1972, the government promoted a family planning policy of "stop at two." And when the fertility rate dropped further in the 1980s, the government revamped the family planning policy to "have three or more, if you can afford it." In 2004, the government introduced new incentives and economic benefits to increase the sub-replacement fertility rate, which was at a rate significantly lower than the natural population replacement rate of 2.1 (Yeung and Hu 2018). To resolve this grave demographic problem, the Singapore government considered bringing in young and highly skilled immigrants. New Chinese immigration to Singapore, which began in the early 1990s and accelerated in the 2000s, was a direct outcome of the government's deliberate policymaking to deal with sub-replacement fertility while strengthening the nation-state's global competitiveness. Unlike the U.S., Singapore's immigration policy leaned heavily toward highly skilled immigration without giving preference to family reunification nor birth-right citizenship to the children of immigrants born in Singapore. However, it was relatively easy for Chinese immigrants to obtain permanent residency and naturalized citizenship, and their relatives to obtain short-term and temporary visas.

Influenced by Singapore's immigration policy, new Chinese immigrants are composed primarily of international students, highly educated professionals, and investment migrants. The age structure is skewed toward younger cohorts of either those at working age or those born to new immigrant families at very young ages. Within the new immigrant family, members may be on different immigrant statuses, some are naturalized citizens, others are PRs, and still others hold temporary visas. Those holding temporary visas face uncertainty in resettlement, which is often the reason for postponing marriage and childbearing. With time, the majority of new Chinese immigrant families transform from couple-only families to nuclear families with young children. However, many families with young children soon become extended families, as the parents of xinyimin come to Singapore on temporary visas to take 
care of their grandchildren. Some xinyimin also send their infants and toddlers back to China to be taken care of by their parents, and then bring them back when it is time for them to be enrolled in kindergarten or first grade, hence forming the split household family of a different kind.

In sum, new Chinese immigrant families in Singapore show some distinctive characteristics compared to their counterparts in the U.S. First, both husband and wife tend to be highly-educated and salaried professionals, and thus have a higher socioeconomic status than native families. Second, a significantly high proportion of new Chinese immigrants hold PR or temporary (work) visas with an uncertain future in permanent settlement in Singapore. Third, in families with children, most of the children are still in their infancy and early childhood. Fourth, for families with young children, many are quasi-extended families with grandparents present either in Singapore on temporary visas or in China.

\section{Challenges Faced by New Chinese Immigrant Parents}

To raise children in new sociocultural environments, new Chinese immigrant parents often face daunting challenges, including not only the language and cultural barriers, but the institutional and socio-structural constraints.

\subsection{The Language Barrier}

The first challenge is the language barrier. In both the U.S., where English is the dominant language, and in multilingual Singapore, where English is the most commonly used official (and working) language, new Chinese immigrants themselves encounter discrimination in the workplace and society either because of a lack of English proficiency or because of accented English (Wang and Lo 2005). When it comes to childrearing, lack of English proficiency creates communication barriers. It limits immigrant parents' access to urgently needed information such as health, daycare and school, and other available public services. It also weakens parental authority as children often act as cultural brokers and translators for their parents (Zhou 2006). For example, Tom, a father of two teenaged children, who worked in Los Angeles Chinatown, lamented, “I don't know how my children are doing in school because I cannot help them with homework and never show up to their school activities, nor the teacher-parent meetings. Even if they joined gangs or ditched school, I wouldn't know it. I just pray to God, wishing that they are okay." In Singapore, even for many new Chinese immigrants who are highly educated and have good English proficiency, their distinct accent can be a problem. For example, Lynn had received a PhD from the best university in Singapore and had lived there for 15 years with two local-born children (10- and 1-year-old). She commented, "at work, it is very important to master not only good English, but also good Singlish (accented English by locals). When we open our mouths to speak, they [bosses or coworkers who are Chinese Singaporean] know we are xinyimin. Our Chinese accented English would create problems for developing good relationships with both superiors and peers at work and even for promotion because we are outsiders. So I'd make sure that my children grow up speaking good English. I also encourage my older child to learn Singlish and make friends with different groups of local children, Chinese, Malays, and Indians ..."

The children also encounter language difficulty, which is inadvertently created by the immigrant family. Raised by immigrant parents and/or grandparents who speak only Chinese at home because of their lack of English language ability, the children often enter school without proficient English. Although parents would want their children to learn English as quickly as possible, they still insist on speaking Chinese to their children at home and take every possible opportunity to push their children to maintain Chinese language proficiency and Chinese identity. In the U.S., Chinese immigrant parents send their children to Chinese schools after regular school hours, even when they are aware that making their children learn Chinese may be a losing battle (Zhou and Li 2003). In Singapore, some parents reported that helping their children learn Chinese and maintain Chinese identity is not only a cultural need of parents, but also a pragmatic choice. They believe that their children's future employment opportunities may be beyond the small island-state and that mastering bilingual or multilingual skills 
would increase one's competitiveness in the global job market. Many parents with children in higher grades of primary school or in secondary schools worry about their children's Chinese proficiency; they think that the children's mastering good English would weaken their Chinese learning ability. Indeed, the children often resist speaking and learning Chinese since English is used in schools and in their social life outside the family.

\subsection{Cultural Barriers}

Cultural difference is another challenge that immigrants face. New Chinese immigrant parents emphasize the Chinese cultural traditions and practices of filial piety, deference to parents and elders, respect for authority, and "family first." They tend to impose strict rules on children while overlooking their children's privacy and individuality, which is incompatible with Western cultural values of individualism, freedom, equality, and critical thinking. In the U.S., such differences in cultural values and practices often lead to intense intergenerational conflict. In Singapore, where the mainstream society is said to be dominated by Chinese culture, new immigrant parents face similar issues associated with cultural differences. This is because native Singaporean Chinese tend to distinguish themselves from both their own parents, who were earlier immigrants, and the new immigrants. Younger Singapore Chinese also strongly adhere to their national identity as "Singaporean" and have little sense of belonging to China or anything Chinese. They also lack proficiency in Chinese language. Although new Chinese immigrants in Singapore are hyper-selected with higher than average levels of education, occupation, and income, they are still at a disadvantaged position in the process of adapting and integrating into Singapore's uniquely East-West blended culture.

\subsection{Institutional Barriers}

In addition, new Chinese immigrants in the U.S. and Singapore are subject to different extents of structural and institutional discrimination. Although larger social environments gradually become more equal, open, and inclusive in both the U.S. and Singapore, new Chinese immigrants still encounter institutional constraints, but in different ways. In the U.S., new Chinese immigrants come into contact with a racial hierarchy, in which their disadvantaged racial status, which subjects them to overt or covert prejudice and discrimination, trumps relatively advantageous class status. Upon arrival in the U.S., many experienced under-employment because their China-acquired education and professional credentials and skills are either non-transferable or unappreciated. They also lack the kind of social capital that would link them to the mainstream labor market and society. These structural constraints not only pressure immigrants to work harder and perform better in the workplace and in society, but make them educate their children about circumventing institutional and racial barriers by working twice as hard and being twice as good as their American peers (Schneider and Lee 1990; Siu 1992).

In Singapore, state policies and institutions, such as immigration policies, rules and regulations, and government agencies, have intentionally or unintentionally engendered a social hierarchy, where immigrants are distinguished along the lines of education, occupation, and class statuses. This hierarchy is consequential for newcomers, as they are offered different types and levels of opportunities and welfare benefits. Christine, a 42-year-old naturalized citizen who had migrated to Singapore more than 10 years ago, said, "Once xinyimin, always xinyimin! Your naturalized citizenship status wouldn't change that. We especially lack the useful social connections and close circles of friends to help support our children's education. In order to ensure that my son gets into the current school, I had to serve as a volunteer at the church a few years before my son's primary school enrolment, just so I could obtain a referral letter from our pastor ... Otherwise you would not know for sure which school your child is allocated to until the last minute. Children of new citizens and PRs do not have equal chance in school allocation, and some of them are subject to lottery for allocation to better schools." The changing immigration policy in Singapore also makes a distinction between different categories of immigrants and citizens. John, an IT engineer holding a PR, said, "If we were citizens, my son's monthly childcare fee would be SG $\$ 500$. But we have to pay more than double that amount. 
So I have to say the current immigration policy does exert heavy burden and pressure on people like me." Lily, the wife of an Employment Pass holder and a homemaker, was frustrated when she talked about her experience. "We wanted to settle down here, but our PR application was rejected twice in the past 3 years. Our family is in good standing financially, and we emphasize on children's education very much. We don't understand why the government rejected our PR application. Without PR, it would be difficult for us to make long-term plans for our children's education."

Moreover, the rapid influx of new immigrants from mainland China, in particular, has aroused local Singaporeans' dissent and resentment. The fear that new immigrants would drain public resources and intensify competition for employment, housing, education, and health services has deepened the social discrimination against new Chinese immigrants. Such hostile public reception creates high uncertainty about long-term resettlement for new Chinese immigrants and generates a keen sense of urgency in pushing their children to do well in school while strengthening their bilingual and bicultural skills for future educational and career prospects outside Singapore.

\subsection{The Generation Gap in the New Chinese Immigrant Family}

The "generation gap" is caused by differences in age, experience, and environment of growing up, which is not a unique phenomenon but is more likely to lead to intergenerational conflicts in immigrant families than native families. In the United States, the generation gap is shaped and exacerbated by a cultural gap between the immigrant family and the larger society as well as by the different paces of acculturation between immigrant parents and their children born or raised in the receiving country. This gap is particularly discernible in the discrepancy in goal orientation and the means of achieving goals between immigrant parents and their U.S.-born or -raised children. Because of immigrant selectivity, most adult immigrants and the parent generation are busy working, focusing first on putting food on the table and then moving themselves or their families up in society. They structure their lives primarily around three goals, as a Chinese immigrant put it: "To live in your own house, to be your own boss, and to send your children to the Ivy League." They too try to acculturate or assimilate into American society but only in ways that facilitate the attainment of these goals (Zhou 2006). The children, in contrast, want more. They aspire to be American like everyone else, and hope to be able to do whatever their hearts desire rather than what their parents tell them to do. This cultural gap sets the parents and children apart, and often dampens the already strained parent-child relations. Children tend to regard their immigrant parents as lao-wan-gu and parental ways as outdated or old-fashioned, and they consciously rebel against parental ways. The parents, aside from juggling work and household responsibilities that devour most of their waking hours, are worried that their children have too much freedom, too little respect for authority. The parents experience difficulty in communicating with their Americanized children and in mediating between their expectations and their children's own needs, which further intensifies intergenerational conflicts. To make matters worse, the parents' customary ways of exercising authority or disciplining children, which were considered normative and acceptable in the old world, have suddenly become obsolete and even illegal, further eroding parental power in parent-child relations (Zhou 2006).

In Singapore, since the children of many new Chinese immigrant families are still young, an intergenerational gap has not yet been visible. There are, however, cases where there is an intergenerational gap between new Chinese immigrants themselves and their parents who come to Singapore to take care of grandchildren. As discussed earlier, new Chinese immigrant families are usually made up of married couples or couples with young children with the latter in need of additional help. Although it is customary for middle-class families to hire domestic helpers, new Chinese immigrant couples tend to seek support from their parents in China. This is a rational, pragmatic family arrangement, not only relieving the couple's financial burden, but also ensuring that their young children are in good and reliable care. The practice of childcare by grandparents is the same as that in China. Such practice by new Chinese immigrants in Singapore has now become a type of transnational grand-parenting, where grandparents come to Singapore to take care 
of their grandchildren. This three-generation, transnational living arrangement complicates family relations and the nature of the generation gap. From the grandparents' perspective, transnational grand-parenting involves a sacrifice. They have to give up their leisure time in retirement to take up grand-parenting responsibilities. In Singapore, they also have to deal with language and cultural problems in an unfamiliar environment on a daily basis. Moreover, they often differ with their immigrant children in parenting philosophy, style, and practices, which often lead to disagreements and intergenerational conflicts in the family. When conflicts occur, they tend to complain and worry that their own children are being too assimilated into the Western culture to be filial or that their own children may not provide them with the needed and expected care when they become old and frail.

\section{Expectations, Strategies, and Support}

\subsection{Extremely High Educational Expectations}

Findings from our comparative study indicate that despite the different social positioning of the Chinese in these two host societies, Chinese immigrant parents in the United States and Singapore show little difference in their expectations for children's education. They share the belief that education plays an instrumental role in individuals and families' prosperity and upward social mobility. In fact, a primary reason for migration among many Chinese immigrant parents is to seek better educational opportunities for their children.

In the United States, new Chinese immigrant parents have extremely high expectations for their children's academic excellence because many view education as the only effective way for their children to circumvent structural barriers and move ahead in society (Lee and Zhou 2015; Sue and Okazaki 1990; Zhou and Kim 2006). Their counterparts in Singapore have similarly high expectations, not only because Chinese Confucian culture values education, but also because the nation-state's meritocratic system judges and selects individuals for jobs and positions of power based on educational excellence. The Singapore government takes education as an important mechanism to develop, plan, and reserve human capital for Singapore's economic development and globalization. The pragmatism of education, intertwined with the experience or exposure to competitive parenting practices in China, further reinforces immigrant parents' belief in meritocracy while intensifying their own concern and anxiety for their children's educational success. For many new Chinese immigrant parents, their children's educational success not merely ensures better career prospects and life chances, but also brings honor to the entire family, and also justifies their decision to migrate. David, who migrated to Singapore 10 years ago through the investment path, showed satisfaction and a sense of pride when he told us that his daughter got into Raffles Institute, the oldest and one of the best pre-tertiary schools in Singapore. He explained, "I used Lang Lang [the famed Chinese pianist] as a role model for my daughter. When she was at Primary 6 [at age 12], I sent her to 20 different tuitions each week for the purpose of preparing her to do well in the PSLE. For us first generation, as pioneers, we sacrifice our lives and everything to make sure that our children achieve the highest level of excellence in education. This would benefit them for life."

\subsection{Outcome-Driven Strategies}

Having high expectations is one thing and realizing these expectations is quite another. New Chinese immigrants tend to design unique strategies that are outcome-driven. These strategies are practiced by Chinese immigrant parents of both middle class and working class backgrounds. The first strategy is to construct a narrowly defined success frame, which is carried over with some modifications from urban middle-class parenting practices in China. This success frame is based on measurable academic outcomes, such as grades and GPAs, exam scores, and enrollment in elite programs and prestigious schools at different levels. Parents believe that, by working hard, their children can achieve success (Lee and Zhou 2015). A second strategy is to guide children into specific subjects of study, such as science, technology, engineering, and mathematics, as well as medicine, finance, 
accounting, and other subjects that can be quantitatively measured. Again, parents believe that their children can score high in these subject by working hard and that having educational qualifications and credentials in these subject areas can presumably lead to well-paying jobs. A third strategy is to invest in afterschool academics and develop particular talents or skills through extracurricular activities. This strategy is supplementary to the other two and consistent with overbearing parenting. Last but not least, the parents' goal is to help children get into the best schools or universities, ensuring that children "win at the starting line."

Our comparative study indicates that in both the United States and Singapore, new Chinese immigrant parents of middle class backgrounds tend to widely adopt these outcome-driven strategies, which are quite different from the class-based childrearing techniques of concerted cultivation or natural growth in America (Lareau 2003). In the case of the United States, immigrant parents of relatively low socioeconomic status also tend to do so.

These strategies seem to be effective. In the United States, the average academic achievement level of the children of Chinese immigrants, regardless of family socioeconomic backgrounds, is higher than that of other racial minorities as well as that of non-Hispanic white (Chao 1994; Lee and Zhou 2015; Yao 1985; Zhou and III 2016). In Singapore, however, it is still too early to make conclusions about outcomes since the children of Chinese immigrants are still quite young.

\subsection{Interaction with Host-Society Institutions}

While Chinese immigrant parenting strategies may be influenced by culture, we find that these unique strategies are shaped by contexts of reception and host-society institutions and supported by familial or ethnic resources. Both the United States and Singapore are developed countries, and their education is superior in dollar-per-student investment, training, and quality. However, the two countries fundamentally differ in their educational philosophy and institutional setup with the U.S. system being open, liberal, and skill-based and the Singaporean system being competitive, meritocratic, and exam-based. In either country, Chinese immigrant parents do not blindly design and adopt strategies that they think effective. Rather, they make sure that their parenting strategies are closely tied to, and modified to fit, the requirements of the formal education system of the host country.

In the United States, kindergarten-to-high school (K-12) education is compulsory and is provided by public and private schools, as well as home schools. The federal government guides education though laws, guidelines, and funding subsidies, but there is no uniformed curriculum, teaching materials, pedagogy, and assessment system at the federal level. State governments formulate policies, set overall standards, mandate standardized tests, administer assessment, and provide support with funds and grants. Within each respective state, local (county and city) governments establish school districts to make day-to-day decisions about all aspects of schooling. Because public schools are supported by local tax revenues, the quality of schools is vastly different by socioeconomic standing of the neighborhood. Public school enrolment is usually tied to one's residential address. Thus, the first step to ensuring a smooth educational trajectory is to enroll children into good schools either by buying into, or by renting in, good school districts (or even by using relatives' addresses). For new Chinese immigrants, the saying about "school district properties" in the ethnic real estate market reflects the primary consideration in home purchase decisions.

Student assessments at each grade level are determined by basic pass-or-fail rather than best scores in state-mandated standardized tests and GPAs. In other words, students having a straight $C$ or a straight A have the same chance of advancing grades, graduating from high school, and getting into a college. However, there is a wide range of school choices and educational opportunities. For example, there are different tracks within regular schools for academic driven students to get into GT (gifted and talented) and honors classes, and enroll in AP (advanced placement) courses and school organized extracurricular activities, such as music, theater, and sports clubs, which add to students' profiles for eventually getting into prestigious universities. There are also different opportunities to enroll in a wide range of post-secondary schools, e.g., junior colleges. And there are many second chances 
for those who want to return to school to receive degrees or professional certifications at later times. The availability of these institutional opportunities provides clear roadmaps and benchmarks for parents to design strategies to ensure their children aim high and do best.

Comparatively, the Singaporean society appears to be more favorable for new Chinese immigrants than the larger society in the United States, in that Singapore is deeply influenced by Confucian culture, and the Chinese occupy a relatively high social position in the multicultural society. However, Singapore has a centralized education system based on meritocracy. The government has full control over education's direction, quality, and standards. Students are screened, streamed, and selected by different levels of examinations, which especially happen in early years of school, leading to highly competitive education. For example, the Gifted Education Programme (GEP) at primary 3 and the Primary School Leave Examination (PSLE) at primary 6 are two important exams in deciding students' educational opportunities and the resources to be obtained.

Although the Singapore government has deliberately reformed the education system by moving away from the narrow focus on grades, e.g., through the 2018 test-free policy, such change has not eased parental worries and anxieties. Chris, a naturalized citizen, who worked as a part-time tutor at a tutoring center, explained, "The education reform did not ease the pressure of competition since high-stake examinations, e.g., PSLE, are maintained. Moreover, the reform aimed for reducing contents in the already crowded curriculum to make learning more fun, meaningful, and reflexive. But what is being tested in examinations has become much deeper and wider than what the children learn from school. Therefore, parents, native or immigrant alike, must invest additional economic resources and time heavily in afterschool work." We observed in Wechat discussions that parents complained that they had to spend more money and time in the realm of academics after school now than before. This situation has consequentially led to increasing demand for supplementary or shadow education (Bray and Lykins 2012; Wise 2016).

Although Singapore's education system offers some opportunities and flexibility for "late bloomers", high-stake examinations and streaming are accepted by the public as benefitting the country's human capital and economic developments, resulting in an excessive involvement of the whole society in education competition (Gee 2012). The country has become a tuition nation, ${ }^{6}$ characteristic of a well-developed, sophisticated private tuition industry to help students boost their grades so they can keep up with their peers and get into top-tier schools, and to meet the urgent needs of anxious parents from different socioeconomic backgrounds. In Singapore, 90 percent of all families (1.2 million families) send their children to afterschool tutoring, including about 40 percent of preschoolers and 80 percent of primary school students. Attending private tuition sessions has become regular for most students at all grade levels on a daily or weekly basis. For example, about 85 percent of children aged 13-19 have to study after school for more than 4 hours a week (Wise 2016).

As educational success is highly valued by the society and educational attainment along with school performance scores are key to getting into good universities or good jobs, new Chinese immigrant parents align their education practices and strategies with the institutional environment, just like the majority of native Singaporean parents. They invest heavily in their children's academic studies and other extracurricular and enrichment activities. Even at pre-school ages, children's lives are highly structured and cramped with activities to improve their literacy, reading, writing, and mathematical learning abilities before they enter regular school. Native Singaporeans refers to parental anxiety over fierce competition as kiasu (fear of losing out). ${ }^{7}$ Both immigrant and native parents actually compete with one another in their children's education to make sure that their children "do not lose at the starting line." Such educational competition not only leads to tremendous pressures and anxieties from high expectations and heavy investment but also intense native resentment of new Chinese immigrant

6 See "Tuition Nation." The Straits Times, 4 July 2015. Available online: http://www.asiaone.com/singapore/tuition-nation (accessed on 25 January 2019).

7 "Kiasu" is a Hokkien term used by Singaporean Chinese to mean the "fear of losing out". 
parents who tend to be more highly educated and economically resourceful. Our data indicated that such fierce education competition led some new Chinese immigrant parents to hold unrealistic expectations of their young children, make their children follow a well-planned, rigid schedule, and inculcate their children with strict self-discipline and self-control. Some parents even accompanied their children to be trained in effective time management and study habits (but not always successfully). Parents often showed intense emotions, such as irritation, anger, frustration, etc., when children could not perform to their standard and satisfaction, and vented their negative emotions on their children.

\subsection{Familial and Ethnic Support}

It is not easy to raise children in a foreign land, whether in the West, like the U.S., or in the East, like Singapore. The challenges that new immigrant parents face add to the level of difficulty. Thus, to actualize a strong pragmatic value on education and to make outcome-driven strategies effective, new Chinese parents, especially those from lower socioeconomic backgrounds, must also rely on available support from familial and ethnic social networks.

In the U.S., the ethnic Chinese community has become an important institutional basis from which immigrants rebuild their social networks and build new ethnic institutions that function as mechanisms of support to influence the social mobility of group members and their children (Zhou and Li 2003). Because of immigrant selectivity, the Chinese immigrant community, lodged in old Chinatowns or ethnoburbs, has developed an ethnic enclave economy and a range of ethnic social and cultural institutions to support the long-term settlement needs of Chinese immigrants. The children- or youth-oriented enterprises, both nonprofit and for-profit, range from weekend Chinese schools to a wider variety of afterschool academies and learning and enrichment centers, such as daily afterschool classes that match formal school curricula, English language classes that help improve reading and writing skills, exam cram schools, college preparation programs, music/dance/sports studios, and other talent training and extracurricular activities. These private enterprises are owned and run by Chinese immigrant entrepreneurs as part of the ethnic economy, which forms the ethnic system of supplementary education to serve primarily Chinese immigrant families (Zhou and Li 2003). The ethnic system of supplementary education is quite unlike the private tuition industry in Singapore. This particular industry has been incorporated into the mainstream economy in Singapore that caters to all Singaporean families, not just the Chinese.

The intended functions of the ethnic system of supplementary education in the Chinese community in the U.S. are to create tangible educational resources and facilitate access to these resources. Participation in these ethnic institutions helps Chinese children and youths improve in learning ability, study habits, and academic performance in school because it adds academic contents, study hours, and learning intensity to students, which indeed yield desirable school outcomes. In addition, intangible resources are also generated. First, Chinese traditional values and a sense of ethnic identity are nurtured among children through participation in these ethnic institutions. For example, young children recite classical Chinese poems and Confucian sayings about family values, behavioral and moral guidelines, and the importance of schooling. Second, ethnic participation nurtures ethnic identity and pride among Chinese youths who may otherwise reject Chinese culture due to pressures to assimilate. It also provides unique opportunities for immigrant children to form a different set of peer group networks, giving them more leverage in negotiating parent-child relations at home. Third, ethnic institutions not only provide important sites where Chinese children and youth meet other co-ethnicity peers, but also allow parents to meet with other parents who share similar concerns and problems and work out strategies to deal with them (Zhou 2006). In sum, ethnic social networks, embedded in the broader Chinese immigrant community, function to reinforce common norms and standards and exercise control over those who are connected to them. Involvement in different types of ethnic institutions also helps families and children alleviate the pressure for achieving while meeting familial and community expectations. For families lacking economic resources, the support of the ethnic community is even more important. 
If new Chinese immigrant parents in the U.S. rely on ethnic institutions and social support networks in the broader Chinese immigrant community to promote their children's education, their counterparts in Singapore address the challenges of increasingly competitive education and its related problems primarily through strong individual human capital, which is associated with economic resources and cultural and social capital. Thanks to immigrant selectivity, most new Chinese immigrants are highly educated and in professional occupations, holding an Employment Pass and S Pass with paths to PR or citizenship or eligibility to apply for dependents' passes for immediate family members. ${ }^{8}$ The nation-state's immigration policy makes it possible for them to access familial resources transnationally when in need, such as sending their parents to Singapore to provide care for young children.

In response to Singapore's fierce educational competition, which is similar to that in China, new Chinese immigrants readily transfer parenting practices from China to Singapore when it is time to raise children. To ensure their parenting strategies are effective in yielding expected outcomes, new Chinese immigrant parents in Singapore are very much like their middle class counterparts in urban China in concentrating on deploying resources wisely. First, they use a good amount of economic resources to tap into public education resources, e.g., selecting good public schools. Specifically, they invest in education through purchasing property in proximity to good schools, by which they claim to gain a competitive advantage for their children through having an edge in the formal education competition, and many do so even before they have children. Second, they invest heavily in good services from the well-established shadow education industry, choosing programs that aim to improve children's school performances and exam scores. Moreover, they also arrange various enrichment programs that are considered crucial in developing and nurturing children's talents such as in music and arts. Third, they not only invest economically in their children's education, but also engage with their children's learning by closely supervising their children's homework and examination preparation and by providing healthy diets, a quiet home environment, and rich cultural goods such as toys, books, and theater and museum visits. Thus, the education competition becomes one that is primarily based on parents' human and cultural capital and economic resources. Although many new Chinese immigrant parents are stressed by their own intense "social-engineering" and educational investment, they strongly believe that their children will become competitive when they grow up.

\section{Conclusions}

In the paper, we address one of the most serious resettlement challenges that new Chinese immigrants face-children's education. We find that, despite different contexts of reception, new Chinese immigrant parents in the United States and Singapore hold similar views and expectations on children's education, are equally concerned about children's achievement outcomes, and tend to adopt overbearing parenting strategies. We also find that, while the traditional Chinese way of parenting is severely challenged in the processes of migration and adaptation, the success in promoting children's academic excellence involves not only the right set of culturally specific strategies but also tangible support from host-society institutions and familial or ethnic social networks.

Chinese immigrant parenting strategies seem to be working, given the fact that the children of new Chinese immigrants in the U.S. and Singapore have achieved academic excellence and that they performed at levels higher than native-born children. In the U.S., even those of low socioeconomic family backgrounds adopt the overbearing parenting strategies, which goes against the class argument by Lareau (2003), and fare better than middle class non-Hispanic whites (Kasinitz et al. 2009; Lee and Zhou 2015). The media and the public jump to the conclusion that there is something unique about the Chinese, Chinese culture, or the "tiger mom" style of overbearing parenting, that explains

8 See "Eligibility for Dependent's Pass." Ministry of Manpower, Singapore. Available online: https://www.mom.gov.sg/passesand-permits/dependants-pass/eligibility (accessed on 2 January 2019). 
the extraordinary educational achievement of immigrant Chinese children. Our comparative analysis suggests that culturally-specific parenting strategies matter, but culture should not be understood as something inherent to an immigrant group. Rather, culture interacts with structure; successful parenting involves not only the right set of cultural values and strategies but also tangible support from host-society institutions and familial and ethnic social networks, in addition to parental human capital and economic resources.

Overbearing parenting strategies practiced by new Chinese immigrants in the U.S. and Singapore, as we have shown, have presumably led to the desirable outcomes expected by parents. However, there are unintended consequences that may affect children negatively in the long run. For example, research in the U.S. has shown that the extraordinary academic achievements of second-generation Chinese Americans has negative effects on Chinese Americans (e.g., Qin et al. 2008; Cherng et al. 2014). At the individual level, overbearing parenting stifles individual drive for learning based not only on interest but also on ability, while depriving children of their intellectual curiosity and critical thinking in subject areas beyond the narrow success frame. At the group level, extraordinary achievement reinforces the "model minority" myth, holding the group up to different (higher) standards while setting it apart from other Americans for prejudiced views and treatment (Zhou 2004; Chou and Feagin 2008). In Singapore, negative impacts of overbearing parenting at the individual level may not pertain to only the children of new Chinese immigrants. However, negative effects at the group level are similar, in that new Chinese immigrant parents who are predominantly highly educated are perceived as posing a real threat to natives in education competition. Thus, future research should pay attention to determinants of these unintended consequences.

Author Contributions: M.Z. was responsible for the theoretical and conceptual framing of the paper, and both authors contributed equally to data analysis.

Funding: The research was supported by funding from the Walter \& Shirley Endowed Chair in US-China Relations and Communications, University of California, Los Angeles, and a graduate research scholarship under the Singapore Ministry of Education Tier 2 Academic Research Grant (no. MoE2015-T2-2-027).

Conflicts of Interest: The authors declare no conflicts of interests.

\section{References}

Abada, Teresa, Feng Hou, and Bali Ram. 2008. Ethnic Differences in Educational Attainment among the Children of Canadian Immigrants. Canadian Journal of Sociology 34: 1-30.

Archer, Louise, and Becky Francis. 2006. Challenging Classes? Exploring the Role of Social Class within the Identities and Achievement of British Chinese Pupils. Sociology 40: 29-49. [CrossRef]

Ash, Alec. 2016. Is China's Gaokao the World's Toughest School Exam. The Guardian. October 12. Available online: https://www.theguardian.com/world/2016/oct/12/gaokao-china-toughest-school-exam-in-world (accessed on 1 February 2016).

Bellows, Thomas J. 2009. Meritocracy and the Singapore Political System. Asian Journal of Political Science 17: 24-44. [CrossRef]

Bray, Mark, and Chad Lykins. 2012. Shadow Education: Private Supplementary Tutoring and its Implications for Policy Makers in Asia. Mandaluyong City: Asian Development Bank.

Chan, Sucheng. 1991. Asian Americans: An Interpretive History. Boston: Twayne.

Chao, Ruth K. 1994. Beyond Parental Control and Authoritarian Parenting Style: Understanding Chinese Parenting through the Cultural Notion of Training. Child Development 65: 1111-19. [CrossRef]

Cherng, H., Kristin Turney, and Grace Kao. 2014. Less Socially Engaged? Participation in Friendship and Extracurricular Activities among Racial/Ethnic Minority and Immigrant Adolescents. Teachers College Record 116: $1-28$.

Chou, Rosalind S., and Joe R. Feagin. 2008. The Myth of the Model Minority: Asian Americans Facing Racism. Boulder: Paradigm Press.

Chua, Beng Huat. 1995. Communitarian Ideology and Democracy in Singapore. London and New York: Routledge. Chua, Amy. 2011. Battle Hymn of the Tiger Mother. New York: Penguin Press. 
Chua, Amy, and Jed Rubenfeld. 2014. The Triple Package: How Three Unlikely Traits Explain the Rise and Fall of Cultural Groups in America. New York: Penguin Press.

Chung, Rita Chi-Ying, Frank H. Walkey, and Fred Bemak. 1997. A Comparison of Achievement and Aspirations of New Zealand Chinese and European Students. Journal of Cross-Cultural Psychology 28: 481-89. [CrossRef]

Freedman, Maurice. 1957. Chinese Family and Marriage in Singapore. Colonial Research Studies No. 20. London: Her Majesty's Stationery Office.

Gee, Christopher. 2012. The Education's Arms Race: All for One, Loss for All. IPS Working Paper No. 20, Lee Kuan Yew School of Public Policy at the National University of Singapore. Available online: https://kyspp. nus.edu.sg/docs/default-source/ips/wp-20_the-educational-arms-race-all-for-one-loss-for-all.pdf (accessed on 2 January 2019).

Glenn, Evelyn Nakano. 1983. Split Household, Small Producer and Dual Wage Earner: An Analysis of Chinese-American Family Strategies. Journal of Marriage and Family 45: 35-46. [CrossRef]

Goh, Keng Swee. 1956. Urban Incomes and Housing: A Report on the Social Survey of Singapore, 1953-54. Singapore: Department of Social Welfare.

Hill, Michael, and Kwen Fee Lian. 1995. The Politics of Nation Building and Citizenship in Singapore. London and New York: Routledge.

Ho, Christina. 2017. The New Meritocracy or Over-Schooled Robots? Public Attitudes on Asian-Australian Education Cultures. Journal of Ethnic and Migration Studies 43: 2346-62. [CrossRef]

Kasinitz, Philip, John H. Mollenkopf, Mary C. Waters, and Jennifer Holdaway. 2009. Inheriting the City: The Children of Immigrants Come of Age. New York: Russell Sage Foundation.

Kaye, Barrington. 1960. Upper Nankin Street, Singapore: A Sociological Study of Chinese Households Living in a Densely Populated Area. Kuala Lumpur: University of Malaya Press.

Lam, Chi-Chung, Esther Sui Chu Ho, and Ngai-Ying Wong. 2002. Parents' Beliefs and Practices in Education in Confucian Heritage Cultures: The Hong Kong Case. Journal of Southeast Asian Education 3: 99-114.

Lareau, Annette. 2003. Unequal Childhoods: Class, Race, and Family Life. Berkeley: University of California Press.

Lee, Jennifer, and Min Zhou. 2015. The Asian American Achievement Paradox. New York: Russell Sage Foundation.

LePoer, Barbara Leitch, ed. 1989. Singapore: A Country Study. Area Handbook Series. Washington: Library of Congress.

Liu, Hong. 2012. Transnational Chinese Sphere in Singapore: Dynamics, Transformations and Characteristics. Journal of Current Chinese Affairs 41: 37-60.

Liu, Ye. 2016. Higher Education, Meritocracy and Inequality in China. Amsterdam: Springer.

Meagher, Arnold J. 2008. The Coolie Trade: The Traffic in Chinese Laborers to Latin America 1847-1874. Bloomington: Xlibris Corporation.

Pew Research Center. 2012. The Rise of Asian Americans. Washington: Pew Research Center.

Portes, Alejandro, and Rubén G. Rumbaut. 1990. Immigrant America: A Portrait. Berkeley: University of California Press.

Qin, Desirée Boalian, Niobe Way, and Preetika Mukherjee. 2008. The Other Side of the Model Minority Story: The Familial and Peer Challenges Faced by Chinese American Adolescents. Youth E Society 39: 480-506.

Quah, Jon S. T., ed. 2010. Public Administration Singapore-Style. Singapore: Talisman.

Saito, Natsu Taylor. 1997. Model Minority, Yellow Peril: Functions of Foreignness in the Construction of Asian American Legal Identity. Asian L.J. 4: 71.

Saw, Swee-Hock. 1969. Population Trends in Singapore, 1819-1967. Journal of Southeast Asian History 10: 36-49.

Saxton, Alexander. 1971. The Indispensable Enemy: Labor and the Anti-Chinese Movement in California. Berkeley: University of California Press.

Schneider, Barbara, and Yongsook Lee. 1990. A Model for Academic Success: The School and Home Environment of East Asian Students. Anthropology \& Education Quarterly 21: 358-77.

Seah, Kelvin Kah Cheng. 2017. Immigrants Outdo Native Students in Studies. The Straits Times. June 14. Available online: https://www.straitstimes.com/opinion/immigrants-outdo-native-students-in-studies (accessed on 1 February 2019).

Singapore Department of Statistics. 2018. Population Trends 2018. Available online: https://www.singstat.gov.sg/-/ media/files/publications/population/population2018.pdf (accessed on 1 January 2019).

Siu, Sau-Fong. 1992. How Do Family and Community Characteristics Affect Children's Education Achievement? The Chinese-American Experience. Equity and Choice 8: 46-9. 
Sue, Stanley, and Sumie Okazaki. 1990. Asian-American Educational Achievements: A Phenomenon in Search of an Explanation. American Psychologist 45: 913-20. [CrossRef]

Tan, Kee Meng. 1965. The Experience of Being Rehoused: Chinese Families in Singapore. Academic Exercise, Department of Social Studies. Singapore: University of Singapore.

Tan, Eugene K. B. 2003. Re-engaging Chineseness: Political, Economic and Cultural Imperatives of Nation-Building in Singapore. The China Quarterly 175: 751-74. [CrossRef]

Tuan, Mia. 1998. Forever Foreigners or Honorary Whites? The Asian Ethnic Experience Today. New Brunswick: Rutgers University Press.

Wang, Gungwu. 1993. Greater China and the Chinese Overseas. The China Quarterly 136: 926-48.

Wang, Shuguang, and Lucia Lo. 2005. Chinese Immigrants in Canada: Their Changing Composition and Economic Performance. International Migration 43: 35-71. [CrossRef]

Warren, James Francis. 1986. Rickshaw Coolie: A People's History of Colonial Singapore, 1880-1940. Singapore: National University of Singapore Press.

Watkins, Megan, Christina Ho, and Rose Butler. 2017. Asian Migration and Education Cultures in the Anglo-sphere. Journal of Ethnic and Migration Studies 43: 2283-99. [CrossRef]

Wise, Amanda. 2016. Behind the World's Best Students Is a Soul-Crushing, Billion-Dollar Private Education Industry. December 12. Available online: https://qz.com/860356/pisa-singapores-competitive-private-tuitionsystem-helps-students-ace-the-worlds-biggest-education-test/ (accessed on 2 January 2019).

Yao, Esther Lee. 1985. A Comparison of Family Characteristics of Asian-American and Anglo-American High Achievers. International Journal of Comparative Sociology 26: 198-208. [CrossRef]

Yeoh, Brenda S. A., and Weiqiang Lin. 2013. Chinese Migration to Singapore: Discourses and Discontents in A Globalizing Nation-state. Asian and Pacific Migration Journal 22: 31-54. [CrossRef]

Yeung, Wei-Jun Jean, and Shu Hu. 2018. Continuity and Change in Singapore's Population and Families. In Family and Population Changes in Singapore: A Unique Case in the Global Family Change. Edited by Wei-Jun Jean Yeung and Shu Hu. London and New York: Routledge, pp. 1-26.

Zheng, Mu, and Shu Hu. 2018. Origin and Transition of Singapore Families. In Family and Population Changes in Singapore: A Unique Case in the Global Family Change. Edited by Wei-Jun Jean Yeung and Shu Hu. London and New York: Routledge, pp. 27-52.

Zhou, Min. 1992. Chinatown: The Socioeconomic Potential of an Urban Enclave. Philadelphia: Temple University Press.

Zhou, Min. 2004. Are Asian Americans becoming White? Context 3: 29-37. [CrossRef]

Zhou, Min. 2006. Negotiating Culture and Ethnicity: Intergenerational Relations in Chinese Immigrant Families in the United States. In Cultural Psychology of Immigrants. Edited by Ram Mahalingam. Mahwah: Lawrence Erlbaum, pp. 315-36.

Zhou, Min, ed. 2017. Contemporary Chinese Diasporas. Singapore: Palgrave Macmillan.

Zhou, Min, and Carl L. Bankston III. 2016. The Rise of the New Second Generation. Cambridge: Polity Press.

Zhou, Min, and Susan S. Kim. 2006. Community Forces, Social Capital, and Educational Achievement: The Case of Supplementary Education in the Chinese and Korean Immigrant Communities. Harvard Educational Review 76: 1-29. [CrossRef]

Zhou, Min, and Xiyuan Li. 2003. Ethnic Language Schools and the Development of Supplementary Education in the Immigrant Chinese Community in the United States. New Directions for Youth Development 100: 57-73. [CrossRef] [PubMed]

Zhou, Min, and Hong Liu. 2016. Homeland Engagement and Host-Society Integration: A Comparative Study of New Chinese Immigrants in the United States and Singapore. International Journal of Comparative Sociology 57: 30-52. [CrossRef]

(C) 2019 by the authors. Licensee MDPI, Basel, Switzerland. This article is an open access article distributed under the terms and conditions of the Creative Commons Attribution (CC BY) license (http://creativecommons.org/licenses/by/4.0/). 

MDPI

St. Alban-Anlage 66

4052 Basel

Switzerland

Tel. +41616837734

Fax +41 613028918

www.mdpi.com

Genealogy Editorial Office

E-mail: genealogy@mdpi.com www.mdpi.com/journal/genealogy

口象安

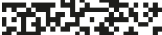
$2+4$ 口宫等 

MDPI

St. Alban-Anlage 66

4052 Basel

Switzerland

Tel: +41 616837734

Fax: +41 613028918

www.mdpi.com 